\title{
НОВЫЕ ИЗОТОПНО-ГИДРОГЕОХИМИЧЕСКИЕ ДАННЫЕ ПО СОСТАВУ ПРИРОДНЫХ ВОД БАЙДАРСКОЙ ДОЛИНЫ (КРЫМСКИЙ ПОЛУОСТРОВ)
}

Новиков Д. А., Копылова Ю. Г., Черных А. В., Дульцев Ф. Ф., Пыряев А. Н., Хващевская А. А., Ничкова Л. А., Сигора Г. А., Яхин Т. А.

Аннотация

Приводятся результаты изучения природных вод Байдарской долины (юго-западные районы Крымского полуострова) полученные по итогам полевых работ 2018-2019 гг. Основные ресурсы подземных вод изучаемого района приурочены к верхнеюрскому водоносному комплексу, играющему ключевую роль в питании водонапорных систем Равнинно-Крымского, АзовоКубанского артезианских бассейнов и гидрогеологической складчатой области мегаантиклинория Горного Крыма. В регионе развиты пресные и ультрапресные воды преимущественно гидрокарбонатного кальциевого состава с величиной общей минерализации от 208 до 1269 мг/дм3. Изученные воды разделены на восемь геохимических групп: 1) зоны региональной трещиноватости карбонатно-терригенных пород подверженных процессам континентального засоления; 2) зоны региональной трещиноватости выщелачивания алюмосиликатов и окисления сульфидов; 3) зоны региональной трещиноватости преимущественно натриевых алюмосиликатов (длительного взаимодействия в системе вода - порода), подверженных процессам континентального засоления; 4) зоны региональной трещиноватости преимущественно натриевых алюмосиликатов, подверженных процессам континентального засоления в условиях антропогенного влияния; 5) трещинно-жильные выщелачивания натриевых алюмосиликатов и окисления сульфидов; 6) трещинно-жильные выщелачивания натриевых алюмосиликатов (длительного взаимодействия в системе вода - порода); 7) трещинно-карстовых; 8) поверхностных, подверженных влиянию процессов континентального засоления. Наиболее защищенные от антропогенного влияния и процессов континентального засоления трещиннокарстовые воды относятся к слабощелочным (рH = 7,7), пресным с минерализацией 444 мг/дм3 и невысокими концентрациями кремния - 2,23 мг/дм3, по составу гидрокарбонатным кальциевым. Воды зоны региональной трещиноватости и трещинно-жильные подвержены влиянию процессов континентального засоления и антропогенной нагрузки. Они характеризуются $\mathrm{pH}$ от нейтральных до щелочных (7,1 - 8,6), преимущественно пресные (269 - 1269 мг/дм3), с средними содержаниями кремния 4,61-4,70 мг/дм3, по составу гидрокарбонатным кальциевым с повышенной ролью сульфат-иона, магния и натрия. Воды реки Черной, Чернореченского водохранилища и озер также подвержены влиянию процессов континентального засоления, слабощелочные (рН = 8,3), умеренно пресные (207-364 мг/дм3), со средними концентрациями кремния $=1,18$ мг/дм3 и гидрокарбонатным кальциевым составом с повышенными содержаниями хлор-иона, магния и натрия. Рассчитанные коэффициенты водной миграции химических элементов в водах фонового состава выстроились следующим образом в порядке убывания: очень сильная интенсивность миграции I17,7 > Br14,4 > сильная Se2,83 > B2,22 > Sr1,46 > Sb1,12 > Be1,07 > Hg1,06 > средняя Zn0,74 > Mo0,50 > Li0,46 > Sc0,41 > Ag0,18 > As0,16 > Si0,123 > $\mathrm{Ba} 0,122>$ слабая $\mathrm{Cr0,10}>\mathrm{Cu} 0,096>\mathrm{Bi0}, 080>\mathrm{Sn} 0,068>\mathrm{Tl} 0,067>\mathrm{P0,062}>\mathrm{Ni0,043}>\mathrm{Ta} 0,040>$ $\mathrm{Ge} 0,034>\mathrm{Cd} 0,028>\mathrm{Fe} 0,026>\mathrm{Rb} 0,024>\mathrm{Co0}, 023>\mathrm{Pb} 0,020>\mathrm{W} 0,017>\mathrm{V0,012}>$ очень слабая (инертная) интенсивность миграции Nb0,008 > Hf0,0033 > Mn0,0031 > La0,0029 > Cs0,0022 > $\mathrm{Ti} 0,0018>\mathrm{Ga} 0,0016>\mathrm{Y} 0,0013>\mathrm{Al} 0,0008>\mathrm{Zr} 0,0008$.

Установлено, что все изученные воды имеют атмосферное происхождение и располагаются вдоль глобальной (GMWL) и локальной (LMWL) линии метеорных вод. Диапазон значений $\delta 180$ в водах меняется от $-9,9$ до -3,3\%о с значениями $\delta \mathrm{D}$ от $-64,2$ до -32,5\%о. Источником $\delta 13 \mathrm{C}$ гидрокарбонатиона в природных водах Байдарской долины служат карбонатные осадочные породы, атмосферный диоксид углерода, органические соединения и гидролиз алюмосиликатных минералов. При этом поверхностные воды имеют более тяжелый изотопный состав $\delta 13 С$ (-9,2 - 
-6,2\%о) за счет атмосферного СО2 и активной жизнедеятельности растений и микроорганизмов. Трещинно-карстовые воды отличаются более легким $\delta 13 C(-12,8--11,0 \%$ о) за счет процессов взаимодействия вод с рассеянным органическим веществом. Воды зоны региональной трещиноватости и трещинно-жильные характеризуются наиболее широкой вариацией $\delta 13 \mathrm{C}(-15,5$ - -6,9\%о), что связано со смешанным типом «изотопного питания» вод. К настоящему времени в Байдарской долине сформировалось сложно построенное гидрогеохимическое поле, на которое все большее влияние начинает оказывать антропогенный фактор.

\section{Ключевые слова:}

Природные воды, гидрогеохимия, микроэлементы, кларк, коэффициент водной миграции, стабильные изотопы, генезис, фракционирование, Байдарская долина, Крым 


\title{
НОВЫЕ ИЗОТОПНО-ГИДРОГЕОХИМИЧЕСКИЕ ДАННЫЕ ПО СОСТАВУ ПРИРОДНЫХ ВОД БАЙДАРСКОЙ ДОЛИНЫ (КРЫМСКИЙ ПОЛУОСТРОВ)
}

\author{
(C) 2019 г. Д.А. Новиков ${ }^{1,2 *}$, Ю.Г. Копылова ${ }^{3}$, А.В. Черных ${ }^{1}$, Ф.Ф. Дульцев ${ }^{1}$, \\ А.Н. Пыряев ${ }^{2,4}$, А.А. Хващевская ${ }^{3}$, Л.А. Ничкова ${ }^{5}$, Г.А. Сигора ${ }^{5}$, Т.А. Яхин \\ ${ }^{1}$ Институт нефтегазовой геологии и геофизики им. А.А. Трофимука СО РАН \\ Россия, 630090 Новосибирск, проспект Академика Коптюга, 3 \\ ${ }^{2}$ Новосибирский национальный исследовательский государственный университет \\ Россия, 630090 Новосибирск, ул. Пирогова, 1 \\ ${ }^{3}$ Проблемная научно-исследовательская лаборатория гидрогеохимии Инженерной школы \\ природных ресурсов Национального исследовательского Томского политехнического \\ университета \\ Россия, 634050, Томск, пр. Ленина, 30 \\ ${ }^{4}$ Институт геологии и минералогии им. В.С. Соболева СО РАН \\ Россия, 630090, Новосибирск, пр. Академика Коптюга, 3 \\ ${ }^{5}$ Севастопольский государственный университет \\ Россия, 299053, Севастополь, ул. Университетская, 33 \\ ${ }^{6}$ Государственное унитарное предприятие города Севастополя «Водоканал» \\ Россия, 299053, Севастополь, ул. Адмирала Октябрьского, 4 \\ *E-mail: NovikovDA@ipgg.sbras.ru \\ Поступила в редакцию 00.00.2019
}

\begin{abstract}
Приводятся результаты изучения природных вод Байдарской долины (юго-западные районы Крымского полуострова) полученные по итогам полевых работ 2018-2019 гг. Основные ресурсы подземных вод изучаемого района приурочены к верхнеюрскому водоносному комплексу, играющему ключевую роль в питании водонапорных систем Равнинно-Крымского, Азово-Кубанского артезианских бассейнов и гидрогеологической складчатой области мегаантиклинория Горного Крыма. В регионе развиты пресные и ультрапресные воды преимущественно гидрокарбонатного кальциевого состава с величиной общей минерализации от 208 до 1269 мг/дм³. Изученные воды разделены на восемь геохимических групп: 1) зоны региональной трещиноватости карбонатно-терригенных пород подверженных процессам континентального засоления; 2) зоны региональной трещиноватости выщелачивания алюмосиликатов и окисления сульфидов; 3) зоны региональной трещиноватости преимущественно натриевых алюмосиликатов (длительного взаимодействия в системе вода - порода), подверженных процессам континентального засоления; 4) зоны региональной трещиноватости преимущественно натриевых алюмосиликатов, подверженных процессам континентального засоления в условиях антропогенного влияния; 5) трещинно-жильные выщелачивания натриевых алюмосиликатов и окисления сульфидов; 6) трещинно-жильные выщелачивания натриевых алюмосиликатов (длительного взаимодействия в системе вода - порода); 7) трещинно-карстовых; 8) поверхностных, подверженных влиянию процессов континентального засоления. Наиболее защищенные от антропогенного влияния и процессов континентального засоления трещинно-карстовые воды относятся к слабощелочным ( $\mathrm{pH}=7,7)$, пресным с минерализацией 444 мг/дм³ и невысокими концентрациями кремния 2,23 мг/дм³ , по составу гидрокарбонатным кальциевым. Воды зоны региональной трещиноватости и трещинно-жильные подвержены влиянию процессов континентального засоления и антропогенной нагрузки. Они характеризуются рН от нейтральных до щелочных $(7,1-8,6)$, преимущественно пресные (269 - 1269 мг/дм³ ), с средними содержаниями кремния 4,61-4,70 мг/дм³, по составу гидрокарбонатным кальциевым с повышенной ролью сульфат-иона, магния и натрия. Воды реки Черной, Чернореченского водохранилища и озер также подвержены влиянию процессов континентального засоления, слабощелочные $(\mathrm{pH}=8,3)$, умеренно пресные (207-364 мг/дм³), со средними концентрациями кремния = 1,18 мг/дм ${ }^{3}$ и гидрокарбонатным кальциевым составом с повышенными содержаниями хлор-иона, магния и натрия. Рассчитанные коэффициенты водной миграции химических элементов в водах фонового состава выстроились следующим образом в порядке убывания: очень сильная интенсивность миграции $\mathrm{I}_{17,7}>\mathrm{Br}_{14,4}>$ сильная $\mathrm{Se}_{2,83}>\mathrm{B}_{2,22}>\mathrm{Sr}_{1,46}>\mathrm{Sb}_{1,12}>\mathrm{Be}_{1,07}>\mathrm{Hg}_{1,06}>$ средняя $\mathrm{Zn}_{0,74}>\mathrm{Mo}_{0,50}>\mathrm{Li}_{0,46}>\mathrm{Sc}_{0,41}>\mathrm{Ag}_{0,18}>\mathrm{As}_{0,16}>$ $\mathrm{Si}_{0,123}>\mathrm{Ba}_{0,122}>$ слабая $\mathrm{Cr}_{0,10}>\mathrm{Cu}_{0,096}>\mathrm{Bi}_{0,080}>\mathrm{Sn}_{0,068}>\mathrm{Tl}_{0,067}>\mathrm{P}_{0,062}>\mathrm{Ni}_{0,043}>\mathrm{Ta}_{0,040}>\mathrm{Ge}_{0,034}>\mathrm{Cd}_{0,028}>\mathrm{Fe}_{0,026}>$ $\mathrm{Rb}_{0,024}>\mathrm{Co}_{0,023}>\mathrm{Pb}_{0,020}>\mathrm{W}_{0,017}>\mathrm{V}_{0,012}>$ очень слабая (инертная) интенсивность миграции $\mathrm{Nb}_{0,008}>\mathrm{Hf}_{0,0033}>$ $\mathrm{Mn}_{0,0031}>\mathrm{La}_{0,0029}>\mathrm{Cs}_{0,0022}>\mathrm{Ti}_{0,0018}>\mathrm{Ga}_{0,0016}>\mathrm{Y}_{0,0013}>\mathrm{Al}_{0,0008}>\mathrm{Zr}_{0,0008}$.
\end{abstract}


Установлено, что все изученные воды имеют атмосферное происхождение и располагаются вдоль глобальной (GMWL) и локальной (LMWL) линии метеорных вод. Диапазон значений $\delta^{18} \mathrm{O}$ в водах меняется от $-9,9$ до $-3,3 \%$ с значениями $\delta \mathrm{D}$ от $-64,2$ до -32,5\%. Источником $\delta^{13} \mathrm{C}$ гидрокарбонат-иона в природных водах Байдарской долины служат карбонатные осадочные породы, атмосферный диоксид углерода, органические соединения и гидролиз алюмосиликатных минералов. При этом поверхностные воды имеют

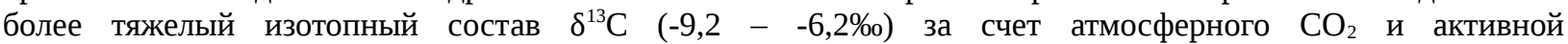
жизнедеятельности растений и микроорганизмов. Трещинно-карстовые воды отличаются более легким $\delta^{13} \mathrm{C}$ $(-12,8--11,0 \%)$ за счет процессов взаимодействия вод с рассеянным органическим веществом. Воды зоны региональной трещиноватости и трещинно-жильные характеризуются наиболее широкой вариацией $\delta^{13} \mathrm{C}(-$ 15,5 - -6,9\%о), что связано со смешанным типом «изотопного питания» вод. К настоящему времени в Байдарской долине сформировалось сложно построенное гидрогеохимическое поле, на которое все большее влияние начинает оказывать антропогенный фактор.

Природные воды, гидрогеохимия, микроэлементы, кларк, коэффициент водной миграции, стабильные изотопы, генезис, фракционирование, Байдарская долина, Крым.

\section{ВВЕДЕНИЕ}

В последние годы все больше исследований в мире проводится по оценке экологического состояния природных вод в условиях изменяющегося климата. По самым оптимистичным прогнозам, среднегодовая температура на Земле вырастет к началу следующего столетия как минимум на два градуса Цельсия вне зависимости от действий человека, что заставит климат планеты необратимым образом поменяться. Волны жары, засухи и другие экстремальные погодные явления, а также рост уровня моря будут гораздо более опасными при повышении температур на два градуса и выше [Raftery et. al., 2017]. О.В. Парубец рассмотрены тенденции изменения температуры воздуха и количества атмосферных осадков на протяжении 80-летнего интервала времени в Крыму. Установлено, что температура воздуха, как и количество атмосферных осадков растут [Парубец, 2009].

Наиболее крупное обобщение по гидрогеологии и гидрогеохимии территории Крыма и Севастопольской городской агломерации было выполнено в VIII томе Гидрогеологии СССР. Крым. под редакцией академика А.В. Сидоренко [Гидрогеология..., 1970; Гидрогеология..., 1971]. Значительный вклад в изучение региона внесли труды А.С. Моисеева, И.Г. Глухова, Е.А. Ришес, В.Г. Ткачук, С.В. Альбова, В.А. Куришко, Е.В. Львова, О.Е. Фесюнова, Н.М. Заезжева, В.И. Самулева, М.В. Чуринова, Н.А. Белокопытовой, В.Н. Дублянского, Г.Н. Дублянской, Н.Н. Капинос, А.В. Лущика, В.И. Морозова, Н.С. Огняника, А.Б. Ситникова, А.А. Сухореброва, В.М. Шестопалова, М.А. 
Шинкаревского, Ю.И. Шутова, Е.А. Яковлева и других [Дублянский и др., 1990]. В период с начала 90-х годов прошлого столетия происходило общее снижением развития экономики, в том числе и геологоразведочных работ. Однако, в этот период продолжалось изучение режима подземных вод основных эксплуатируемых горизонтов, грунтовых вод на массивах орошаемого земледелия, обобщение результатов ранее выполненных исследований, эколого-гидрогеологический анализ состояния подземных вод отдельных водозаборов, разрабатывались методические положения по эколого-гидрогеологическому картированию мелкого и среднего масштабов. Следует отметить работы И.Б. Абрамова, Б.М. Данилишина, С.П. Иванюты, А.В. Лущика, Г.Г. Лютого, Н.С. Огняника, С.А. Рубана, В.М. Шестопалова, М.А. Шинкаревского, Е.А. Яковлева и других [Шестопалов и др., 2007; Тарасенко и др., 2013; Каюкова, Юровский, 2016; Лущик и др., 2016; Горобцов и др., 2017; Новиков и др., 2018; Новиков и др., 2019а; Новиков и др., $2019 б$ и другие].

Байдарская долина расположена в живописной области на юго-западе Крымского полуострова в пределах Балаклавского района Севастопольской городской агломерации. Долина с южной и восточной стороны примыкает к главной гряде Крымских гор (Форос, Ат-Баш, Ай-Петри и другие) (рис. 1). С гидрогеохимической точки зрения природные воды рассматриваемого региона являются слабо изученными [Миньковская, Ингеров, 2010; Дублянский и др., 2012; Nichkova et al., 2019; Novikov et al., 2019].

\section{ФАКТИЧЕСКИЙ МАТЕРИАЛ И МЕТОДИКА ИССЛЕДОВАНИЙ}

В 2018-2019 году нами впервые проведено детальное изучение геохимии и изотопного состава природных вод Байдарской долины. Выполнен отбор и анализ 43 водных проб на полный химический и изотопный состав $\left(\delta \mathrm{D}, \delta^{18} \mathrm{O}, \delta^{13} \mathrm{C}\right)$. Пробы для анализа катионов и анионов отфильтровывались через целлюлозный фильтр (0.45 мкм) на месте отбора для удаления взвеси с помощью системы вакуумной фильтрации и собирались в полиэтиленовые бутыли. Для достоверного определения устойчивых компонентов в растворе на месте отбора пробы консервировались (для анализа катионов 
проба подкислялась азотной кислотой, для анионов - нет), после чего доставлялись в лаборатории для последующего анализа. Нестабильные параметры (pH, Eh, температура, содержание растворенного $\mathrm{O}_{2}, \mathrm{HCO}_{3}{ }^{-}$) определялись на точке отбора проб воды с помощью полевой гидрогеохимической лаборатории и полевого оборудования (Hanna HI9125, кислородомер АКПМ-1-02Л), выполнялось полевое определение общей минерализации вод (кондуктометр S3-Field kit Seven2Go, Mettler Toledo). Радиационная обстановка на месте отбора проб оценивалась с помощью дозиметра гамма-излучения ДКГ-07Д Дрозд.

Лабораторное изучение ионно-солевого, микрокомпонентного, состава методами титриметрии, ионной хроматографии, масс-спектрометрии с индуктивно связанной плазмой (ИСП), проводилось в Проблемной научно-исследовательской лаборатории гидрогеохимии Инженерной школы природных ресурсов Национального исследовательского Томского политехнического университета и в лабораториях центра коллективного пользования Института неорганической химии им. А.В. Николаева СО РАН. В лабораториях центра коллективного пользования Института геологии и минералогии им. В.С. Соболева СО РАН был выполнен комплекс изотопных исследований $\left(\delta \mathrm{D}, \delta^{18} \mathrm{O}, \delta^{13} \mathrm{C}\right)$ подземных вод на приборе Stable Isotope Ratio Mass Spectrometer. Finnigan $^{\mathrm{TM}}$ MAT 253, снабженном приставками пробоподготовки Finnigan GasBench II (для анализа стабильных изотопов углерода и кислорода) и Finnigan H/Device (для анализа стабильных изотопов водорода) Метод измерения: масс-спектрометрическое определение отношений стабильных изотопов $\delta^{13} \mathrm{C}, \delta \mathrm{D}$ и $\delta^{18} \mathrm{O}$ в воде. Для изучения изотопного состава растворенного в воде неорганического углерода (Dissolved Inorganic Carbon (DIC)) применяется несколько методик извлечения углекислого газа из раствора [Handbook of..., 2004]. В настоящей работе была использована методика, описанная в работе [Das et al., 2005], преобразованная для проточного режима работы прибора. Исследование изотопного состава кислорода вод проводилось по методике водного уравновешивание ${ }^{18} \mathrm{O}$ (Water Equilibration $\left.\left({ }^{18} \mathrm{O}\right)\right)$ [Epstein, Mayeda, 1953], модифицированной для проточного режима 
работы прибора [Coplen, 1988; Nelson, 2000]. Анализ изотопного состава водорода проводился для восстановленного на хроме $\mathrm{H}_{2}$ из воды в H/Device согласно методике, описанной в [Yano et al., 2006]. Определения изотопных отношений $\delta^{13} \mathrm{C}, \delta \mathrm{D}$ и $\delta^{18} \mathrm{O}$ проводились относительно мировых стандартов: NBS-18 (International Atomic Energy Agency (IAEA): $\delta^{13} \mathrm{C}_{\mathrm{VPDB}}=-5,014 \%$; $\delta^{18} \mathrm{O}_{\mathrm{VPDB}}=-23,2 \%$ ); NBS-19 (IAEA: $\delta^{13} \mathrm{C}_{\mathrm{VPDB}}=+1,95 \%$; $\delta^{18} \mathrm{O}_{\mathrm{VPDB}}=-2,20 \%$ ); VSMOW2 (IAEA: $\delta D_{\mathrm{VSMOW} / \text { LLAP }}=0 \% ; \delta^{18} \mathrm{O}_{\mathrm{VSMOW} / \mathrm{SLAP}}=0 \%$ ); SLAP2 $\left(\mathrm{IAEA}: \delta \mathrm{D}_{\mathrm{VSMOW} / \mathrm{SLAP}}=-427,5 \% ; \quad \delta^{18} \mathrm{O}_{\mathrm{VSMOW} / \text { LLAP }}=-55,5 \%\right.$ ); GISP $\left(\right.$ IAEA: $\delta D_{\mathrm{VSMOW} / \mathrm{SLAP}}=$ $-189,5 \%$; $\delta^{18} \mathrm{O}_{\mathrm{VSMOW} / \mathrm{SLAP}}=-24,76 \%$ ). Ошибка определения изотопного состава стандартов по углероду и кислороду - не более 0,1 \%, по водороду - не более 2 \%о.

Полученные результаты аналитических исследований приведены в таблицах 1-3.

\section{РЕЗУЛЬТАТЫ И ИХ ОБСУЖДЕНИЕ}

\section{Гидрогеологическая характеристика исследуемого региона}

Основные ресурсы подземных вод изучаемого района приурочены к верхнеюрскому водоносному комплексу, имеющему особую роль, поскольку с ним связаны основные области питания для водонапорных систем: Равнинно-Крымского, Азово-Кубанского артезианских бассейнов и гидрогеологической складчатой области мегаантиклинория Горного Крыма. Водоносный комплекс верхнеюрских отложений ( $\left.\mathrm{J}_{3}\right)$ включает в себя водоносный горизонт средне-верхнетитонских отложений $\left(\mathrm{J}_{3} \mathrm{tt}_{2-3}\right)$, нижнетитонский водоупорный горизонт $\left(\mathrm{J}_{3} \mathrm{tt}_{1}\right)$ и водоносный горизонт средневерхнеоксфордско-кимериджских отложений $\left(\mathrm{J}_{3} \mathrm{O}_{2-3}-\mathrm{J}_{3} \mathrm{~km}\right)$ (рис. 2). Изучен Скважинами Родниковского водозабора (№ 5531, 5566, 5595, 5770 и другими) и многочисленными источниками (Скельский основной, Мердвен-Каясы и другими). Его мощность достигает 2000 м. Детальная характеристика его гидрогеологических особенностей приведена в работах [Новиков, 2018; Новиков, 2019а; Новиков, 2019б].

Циркуляция вод из области питания на Ай-Петринской яйле в Байдарскую долину происходит с огромной скоростью. Несмотря на небольшую долю карстовых каналов в 
общем объеме пустотности растворимых пород (обычно в пределах 0,05 - 3 \%), они проводят 94 - 99 \% подземного стока [Worthington et al, 2000]. Скорости движения подземных вод в карстовых каналах на 3-7 порядков выше, чем в некарстовых водоносных системах зоны активного водообмена, обычно составляя сотни и тысячи метров в сутки. По результатам 35 экспериментов по трассированию карстовых вод, проведенного в разные годы в Горном Крыму, средняя скорость их движения составляет 3350 м/сут (140 м/час; 0,04 м/с), причем эту оценку можно считать заниженной, поскольку регистрация времени прихода трассеров в пункты наблюдений в большинстве экспериментов была малодискретной, а эксперименты проводились не в периоды высокой обводнённости [Климчук, Токарев, 2014]. При этом в периоды весеннего снеготаяния и дождевых паводков на северо-восточном склоне Байдарской долины, кроме нескольких известных родников и активных пещер-источников, появляется множество периодически действующих водопунктов, приуроченных к диапазонам высот 300-400 и 600-800 м [Амеличев, Матюшкин, 2011]. Согласно балансовой оценке величина инфильтрации в глубокие водоносные горизонты Байдарской котловины со стороны массива Ай-Петри составляет около 162,7 тыс. м³/сут. [Приблуда и др., 1979].

\section{Особенности геохимии природных вод}

В Байдарской долине развиты пресные и ультрапресные воды преимущественно гидрокарбонатного кальциевого состава (по С.А. Щукареву) с величиной общей минерализации от 207,4 до 1268,8 мг/дм³ (рис. 3, табл. 1). Большинство изученных вод характеризуется соленостью, не превышающей 1 г/дм³ , что связано с формированием их химического состава в сильно закарстованных известняках верхнеюрского возраста, образованных в условиях карбонатной платформы северной активной окраины Тетиса [Рудько и др., 2017; Рудько, 2018]. Разделение имеющихся данных на однородные совокупности по геохимическим коэффициентам (Ca/Na, Ca/Mg, $\mathrm{Ca} / \mathrm{Si}, \mathrm{Mg} / \mathrm{Si}, \mathrm{Na} / \mathrm{Si}$, $\mathrm{Si} / \mathrm{Na}, \mathrm{rNa} / \mathrm{rCl}$ и $\mathrm{SO}_{4} / \mathrm{Cl}$ ) позволило проследить источники поступление элементов при 
формировании вод в карбонатных, карбонатно-терригенных, алюмосиликатных, в том числе с вкраплениями сульфидов породах.

Подверженность вод процессам континентального засоления характеризуется значениями коэффициента $\mathrm{SO}_{4} / \mathrm{Cl}=1$ и проявляется в их широком влиянии на состав грунтовых вод зоны региональной трещиноватости. По соотношению распространенности магния и натрия при близких значениях коэффициентов $\mathrm{Mg} / \mathrm{Si}$ и $\mathrm{Na} / \mathrm{Si}$ прослеживается взаимодействие вод с карбонатно-терригенными породами при значениях $\mathrm{Ca} / \mathrm{Si}=25,3$ и $\mathrm{Ca} / \mathrm{Na}=7,4$. Значения $\mathrm{Ca} / \mathrm{Mg}=12,5$ на начальных стадиях взаимодействия при средних значениях $\mathrm{rNa} / \mathrm{rCl}=1,1$. При взаимодействии вод зоны региональной трещиноватости с сульфидной минерализацией увеличиваются средние значения $\mathrm{SO}_{4} / \mathrm{Cl}$ до 2,0 по сравнению с их значениями в водах, подверженных процессам континентального засоления, где $\mathrm{SO}_{4} / \mathrm{Cl}=1,1$. При увеличении роли алюмосиликатных пород за счет времени их взаимодействия с водами значения $\mathrm{Na} / \mathrm{Si}$ превышают значения $\mathrm{Mg} / \mathrm{Si}$ и снижаются отношения $\mathrm{Ca} / \mathrm{Mg}=8,1$, а коэффициент $\mathrm{Ca} / \mathrm{Na}$ в среднем снижается до 3,9, несколько уменьшаются значения $\mathrm{Ca} / \mathrm{Si}=20,7$ и повышаются средние значения $\mathrm{rNa} / \mathrm{rCl}=1,4$. B условиях антропогенного влияния в грунтовых водах величины коэффициента $\mathrm{Na} / \mathrm{Si}$ в среднем повышаются до 16,6, значения $\mathrm{Mg} / \mathrm{Si}$ до 4,3, снижаются значения $\mathrm{Ca} / \mathrm{Na}$ до 1,8 и практически не изменяются значения отношений $\mathrm{Ca} / \mathrm{Mg}=7,5$ и $\mathrm{rNa} / \mathrm{rCl}=1,4$.

Трещинно-жильные воды в алюмосиликатных образованиях по соотношению химических элементов проявляются с одной стороны высокими средними значениями $\mathrm{SO}_{4} / \mathrm{Cl}=7,3$ (при взаимодействии вод с сульфидами) и низкими значениями $-\mathrm{SO}_{4} / \mathrm{Cl}=0,3$ (в условиях длительного взаимодействия вод с алюмосиликатами). Характеризуются высокими значениями $\mathrm{Na} / \mathrm{Si}=5,3, \mathrm{Mg} / \mathrm{Si}=3,5, \mathrm{Ca} / \mathrm{Mg}=7,1$, низкими значениями $\mathrm{Ca} / \mathrm{Na}=$ 4,9 и $\mathrm{Ca} / \mathrm{Si}=25,1$. Наиболее яркими их представителями являются колодцы села Санаторное. Отнесение источника Мердвен-Каясы к трещинно-жильным водам 
алюмосиликатов является условным, поскольку эти воды могут быть связаны с карбонатными образованиями с вкраплениями сульфидов.

При взаимодействии с карбонатными породами в трещинно-карстовых водах характерны невысокие фоновые значения $\mathrm{Na} / \mathrm{Si}=2,0, \mathrm{Mg} / \mathrm{Si}=2,5$ и значения $\mathrm{rNa} / \mathrm{rCl}=1,0$. Высокие средние значения отношения $\mathrm{Ca} / \mathrm{Si}=44,1, \mathrm{Ca} / \mathrm{Mg}=18,5$ и особенно по сравнению с другими разновидностями значения отношения $\mathrm{Ca} / \mathrm{Na}=23,3$ являются отличительной чертой состава трещинно-карстовых вод.

Дадим краткую характеристику выделенных типов вод по геохимическим разновидностям (группы I-VIII) (см. табл. 1). Воды зоны региональной трещиноватости карбонатно-терригенных пород, подверженные влиянию процессов континентального засоления (группа I) - слабощелочные с средними значениями $\mathrm{pH}=7,8$; собственно пресные с минерализацией 543 мг/дм³ (по классификации С.Л. Шварцева [Шварцев, 1996]) и содержанием кремния 4,3 мг/дм³. Воды гидрокарбонатные с долей сульфатов и хлоридов до 10\%-экв преимущественно кальциевые с долей магния до 24\%-экв в роднике Деспита, и до 10\%-экв натрия в родниках Чертова лестница и Q 044. По соотношению распространенности магния и натрия при близких значениях $\mathrm{Mg} / \mathrm{Si}$ и $\mathrm{Na} / \mathrm{Si}$ прослеживается взаимодействие вод с карбонатно-терригенными образованиями при значениях $\mathrm{Ca} / \mathrm{Si}=25,3, \mathrm{Ca} / \mathrm{Na}=7,4$, значения $\mathrm{Ca} / \mathrm{Mg}=12,5$ говорят о начальных стадиях взаимодействия в системе вода - порода при средних значениях $\mathrm{rNa} / \mathrm{rCl}=1,05$.

При взаимодействии вод зоны региональной трещиноватости с сульфидной минерализацией (группа II) в условиях континентального засоления воды слабощелочные с $\mathrm{pH}=7,63$, собственно пресные с средней минерализацией 506 мг/дм³ и содержанием кремния 4,3 мг/дм³ Эти воды практически не отличаются от вышерассмотренных и их следует включить в воды зоны региональной трещиноватости карбонатно-терригенных образований. Для них характерно только повышение средних значений $\mathrm{SO}_{4} / \mathrm{Cl}=1,9$ по 
сравнению с типичными водами зон региональной трещиноватости в условиях континентального засоления, где $\mathrm{SO}_{4} / \mathrm{Cl}=1,1$.

Воды зоны региональной трещиноватости преимущественно натриевых алюмосиликатов (длительного взаимодействия в системе вода - порода), подверженных процессам континентального засоления (группа III). По составу воды слабощелочные с рН - 7,66; собственно пресные средней минерализации 659 мг/дм³ и содержанием кремния 5,7 мг/дм³ ; гидрокарбонатные с долей хлоридов до 15\%-экв в фонтане Варналы в с. Гончарное и долей сульфат-иона до 10,7-12,0\%-экв в источнике Кара-Агач и фонтане Варналы (см. табл. 1). При увеличении роли алюмосиликатных образований за счет взаимодействия с водами значения $\mathrm{Na} / \mathrm{Si}$ превышают значения $\mathrm{Mg} / \mathrm{Si}$ и снижаются значения $\mathrm{Ca} / \mathrm{Mg}=8,1$ и значения $\mathrm{Ca} / \mathrm{Na}$ в среднем снижаются до 3,9, несколько уменьшаются значения $\mathrm{Ca} / \mathrm{Si}=$ 20,7 и повышаются средние значения $\mathrm{rNa} / \mathrm{rCl}=1,4$.

Воды зоны региональной трещиноватости преимущественно натриевых алюмосиликатов, подверженных процессам континентального засоления в условиях антропогенного влияния (группа IV) слабощелочные с рН=7,59 собственно пресные с минерализацией 889 мг/дм³ и содержанием кремния 5,0 мг/дм³; гидрокарбонатнохлоридные кальциевые, сульфатно-гидрокарбонатно-хлоридные кальциево-натриевые с долей хлорид-иона до 20-30\%-экв и до 20\%-экв нитратов в центральных колодцах № 1 и 2 в селе Колхозное. В условиях антропогенного влияния в грунтовых водах значения Na/Si в среднем повышаются до 16,5, значения $\mathrm{Mg} / \mathrm{Si}$ до 4,3, снижаются значения $\mathrm{Ca} / \mathrm{Na}$ до 1,8 и практически не меняющиеся значения отношений $\mathrm{Ca} / \mathrm{Mg}=7,5$ и rNa/rCl = 1,5.

Трещинно-жильные воды в алюмосиликатных образованиях (группы $V$ u VI) слабощелочные с рH 7,2-8,6 (среднее значение - 7,7) с средней минерализацией 580 мг/дм³ и содержанием кремния 4,6 мг/дм³; гидрокарбонатные и гидрокарбонатно-сульфатные кальциевые с долей хлоридов до 14\%-экв при содержании хлорид-иона 48,6 мг/дм³ колодце Санаторный нижний. В источниках Мердвен Каясы и Странный отмечаются 
высокие доли сульфат-иона до 32,6-38,5\%-экв соответственно. Трещинно-жильные воды в алюмосиликатных образованиях по соотношению химических элементов проявляются с одной стороны высокими средними значениями $\mathrm{SO}_{4} / \mathrm{Cl}=7,3$ (при взаимодействии вод с сульфидами) и низкими значениями $-\mathrm{SO}_{4} / \mathrm{Cl}=0,3$ (в условиях длительного взаимодействия вод с алюмосиликатами). Характеризуются высокими значениями $\mathrm{Na} / \mathrm{Si}=$ 5,3, $\mathrm{Mg} / \mathrm{Si}=3,5, \mathrm{Ca} / \mathrm{Mg}=7,1$, низкими значениями $\mathrm{Ca} / \mathrm{Na}=4,9$ и $\mathrm{Ca} / \mathrm{Si}=25,1$.

Трещинно-карстовые воды (группа VII) формируются при взаимодействии с карбонатными образованиями и содержат фоновые значения $\mathrm{SO}_{4}$ которые в среднем составляют 8,2 мг/дм³ , а $\mathrm{Cl}=5,1$ мг/дм³ . Они слабощелочные с $\mathrm{pH}=7,7$; пресные с минерализацией 444 мг/дм ${ }^{3}$ и невысокими концентрациями кремния - 2,29 мг/дм³; гидрокарбонатные кальциевые. Характерны значения $\mathrm{Na} / \mathrm{Si}=2,0, \mathrm{Mg} / \mathrm{Si}=2,5, \mathrm{rNa} / \mathrm{rCl}=1,0$. Высокие средние значения отношения $\mathrm{Ca} / \mathrm{Si}=44,1, \mathrm{Ca} / \mathrm{Mg}=18,5$ и особенно по сравнению с другими разновидностями значения отношения $\mathrm{Ca} / \mathrm{Na}=23,3$ являются отличительной чертой состава трещинно-карстовых вод. У Скельского источника $\mathrm{Ca} / \mathrm{Na}=$ 34,7, а содержания кремния снижаются до 2,0 мг/дм³.

Поверхностные воды (групnа VIII) подвержены влиянию процессов континентального засоления. Они слабощелочные с $\mathrm{pH}=8,3$ и окислительными условиями геохимической обстановки с содержаниями растворённого кислорода от 8,63 до 12,25 мг/дм³; умеренно-пресные с минерализацией 267 мг/дм³ и содержанием кремния 1,2 мг/дм ${ }^{3}$ гидрокарбонатного кальциевого состава в реке Черной и Чернореченском водохранилище, гидрокарбонатно-хлоридного кальциевого с повышенной долей натрия до 20\%-экв в озере села Гончарное и гидрокарбонатно-хлоридного кальциевого в озере Конюшня села Орлиное.

Природные воды фонового ${ }^{1}$ состава в пределах Байдарской долины относятся к нейтральным (рН = 7,4), гидрокарбонатным кальциевым, умеренно пресным с величиной

1 Под гидрогеохимическим фоном понимается средняя из наиболее часто встречающихся концентраций элемента. 
общей минерализации 497 мг/дм³ (см. табл. 1). Отмечается закономерное поведение основных химических элементов $\left(\mathrm{Ca}^{2+}, \mathrm{Mg}^{2+}, \mathrm{Na}^{+}, \mathrm{K}^{+}, \mathrm{HCO}_{3}^{-}, \mathrm{Cl}^{-}, \mathrm{NO}_{3}^{-}\right.$и $\left.\mathrm{SO}_{4}^{2-}\right)$ с увеличением общей минерализации природных вод и их химическим типом (рис. 4).

Изученные воды имеют интересный спектр распределения микроэлементов (табл. 2). Средние концентрации для поверхностных, трещинно-карстовых и грунтовых (зоны региональной трещиноватости и трещинно-жильных) вод приведены на рисунке 6а. Среди них, наиболее высокие содержания отмечаются в грунтовых водах (мкг/дм³): Si до 4684, Sr до 601, Fe до 200, Br до 79,3, В до 64,1, Р до 59,1 и т.д. Вторая группа микроэлементов (Cu, $\mathrm{Cr}, \mathrm{Ti}, \mathrm{Rb}, \mathrm{Ni}, \mathrm{As}, \mathrm{Se}, \mathrm{Sc}, \mathrm{Mo}, \mathrm{V}, \mathrm{Pb}$, Со и $\mathrm{Sb})$ характеризуются концентрациями в растворе от 0,14 до 2,24 мкг/дм³. Третья группа (Y, Zr, Sn, Te, La, Hg, Be, Cd, Ag, W, Ga, Ge и Cs) объединяет элементы с содержаниями от 0,008 до 0,049 мкг/дм ${ }^{3}$ и четвертая (Bi, Nd, Hf, Ta, In и $\mathrm{Tl}$ ) соответствует концентрациям ниже 0,006 мкг/дм³ ${ }^{3}$ C ростом общей минерализации в растворе накапливается ряд микроэлементов ( $\mathrm{Si}, \mathrm{Sr}, \mathrm{Fe}, \mathrm{Br}, \mathrm{B}, \mathrm{Ba}, \mathrm{Zn}, \mathrm{Li}, \mathrm{Ni}, \mathrm{Sc}, \mathrm{Co}, \mathrm{La}$, Cd и In) (рис. 5б-г), а поведение P, Mn, I, Al, Cu, Cr, Ti, Rb, As, Se, Mo, V, Pb, Sb, Y, Zr, Sn, Te, Hg, Be, Ag, W, Ga, Ge, Cs, Bi, Nb, Hf, Tа и Tl носит более сложный характер.

Сравнительный анализ содержаний микроэлементов в изученных водопунктах (см. табл. 2) с водами фонового состава позволил установить ряд комплексных гидрогеохимических аномалий по содержанию (мкг/дм³ $)$ : $\mathrm{Si}>5444 ; \mathrm{Sr}>412 ; \mathrm{Fe}>210$; $\mathrm{Br}$ $>$ 62,4; $\mathrm{B}>61,4 ; \mathrm{P}>$ 22,2; $\mathrm{Ba}>33 ; \mathrm{Mn}>1,8 ; \mathrm{Zn}>14,4 ; \mathrm{I}>14,55 ; \mathrm{Al}>$ 7,05; $\mathrm{Li}>6,15 ; \mathrm{Cu}>$ 1,5; $\mathrm{Cr}>1,5 ; \mathrm{Ti}>0,81 ; \mathrm{Rb}>0,47 ; \mathrm{Ni}>0,62 ; \mathrm{As}>0,51$; $\mathrm{Se}>0,57$; $\mathrm{Sc}>0,53$; Mo $>0,6$; V > 0,45; $\mathrm{Pb}>0,11 ; \mathrm{Co}>0,09 ; \mathrm{Sb}>0,21 ; \mathrm{Y}>0,03 ; \mathrm{Zr}>0,03 ; \mathrm{Sn}>0,04 ; \mathrm{Te}>0,12 ; \mathrm{La}>0,015 ; \mathrm{Hg}$ $>0,03 ; \mathrm{Be}>0,024 ; \mathrm{Cd}>0,012 ; \mathrm{Ag}>0,008 ; \mathrm{W}>0,015 ; \mathrm{Ga}>0,006 ; \mathrm{Ge}>0,009 ; \mathrm{Cs}>0,005 ; \mathrm{Bi}$ $>0,003 ; \mathrm{Nb}>0,0045 ; \mathrm{Hf}>0,0015 ; \mathrm{Ta}>0,003$ и $\mathrm{Tl}>0,003$. Природа их возникновения связана с проявлением различных геологических и антропогенных факторов. Уровень концентраций отражает специфику химического элемента и миграционной способности. 
Так, в воде реки Черной обнаружены высокие концентрации марганца до 170 мкг/дм ${ }^{3}$ при региональном гидрогеохимическом фоне 1,8 мкг/дм ${ }^{3}$. Он концентрируется также в грунтовых водах, чего не наблюдается в трещинно-карстовых (см. рис. 5а). Потенциальным источником высоких концентраций марганца в речных водах можно считать проявления марганцевых руд, расположенных в непосредственной близости от изучаемого водопункта (см. рис. 1), но этот вопрос требует детальных минералогических исследований.

Среди геологических факторов литолого-минералогические особенности водовмещающих пород выступают основными при протекании процессов формирования химического состава природных вод. А.И. Перельманом [Перельман, 1975] был предложен метод оценки водной миграции химических элементов в зоне гипергенеза по коэффициенту $\left(\mathrm{K}_{\mathrm{x}}\right)$, который определяется как отношение содержания химического элемента в минеральном остатке воды к его содержанию в водовмещающих породах или кларку литосферы. Этот коэффициент отражает интенсивность водной миграции, определяемую свойствами самого элемента, а также степень его концентрирования или рассеяния в природных водах. Нами для расчетов были использованы средние содержания химических элементов в карбонатных породах [Григорьев, 2009]. Рассчитанные коэффициенты водной миграции химических элементов в водах фонового состава выстроились следующим образом в порядке убывания: очень сильная интенсивность миграции $\mathrm{I}_{17,7}>\mathrm{Br}_{14,4}>$ сильная $\mathrm{Se}_{2,83}>\mathrm{B}_{2,22}>\mathrm{Sr}_{1,46}>\mathrm{Sb}_{1,12}>\mathrm{Be}_{1,07}>\mathrm{Hg}_{1,06}>$ средняя $\mathrm{Zn}_{0,74}>$ $\mathrm{Mo}_{0,50}>\mathrm{Li}_{0,46}>\mathrm{Sc}_{0,41}>\mathrm{Ag}_{0,18}>\mathrm{As}_{0,16}>\mathrm{Si}_{0,123}>\mathrm{Ba}_{0,122}>$ слабая $\mathrm{Cr}_{0,10}>\mathrm{Cu}_{0,096}>\mathrm{Bi}_{0,080}>\mathrm{Sn}_{0,068}>$ $\mathrm{Tl}_{0,067}>\mathrm{P}_{0,062}>\mathrm{Ni}_{0,043}>\mathrm{Ta}_{0,040}>\mathrm{Ge}_{0,034}>\mathrm{Cd}_{0,028}>\mathrm{Fe}_{0,026}>\mathrm{Rb}_{0,024}>\mathrm{Co}_{0,023}>\mathrm{Pb}_{0,020}>\mathrm{W}_{0,017}>$ $\mathrm{V}_{0,012}>$ очень слабая (инертная) интенсивность миграции $\mathrm{Nb}_{0,008}>\mathrm{Hf}_{0,0033}>\mathrm{Mn}_{0,0031}>\mathrm{La}_{0,0029}$ $>\mathrm{Cs}_{0,0022}>\mathrm{Ti}_{0,0018}>\mathrm{Ga}_{0,0016}>\mathrm{Y}_{0,0013}>\mathrm{Al}_{0,0008}>\mathrm{Zr}_{0,0008}$. Ряды миграции элементов в поверхностных, грунтовых (зоны региональной трещиноватости и трещинно-жильных) и трещинно-карстовых водах приведены на рисунке 5д. 
Установлены некоторые особенности поведения элементов в природных водах Байдарской долины по сравнению с классической схемой А.И. Перельмана [Основы..., 1982]. Так, бор перешел в класс элементов, обладающих сильной миграционной способностью, молибден - в класс средней, а цезий - в класс слабой и очень слабой. При этом бериллий передвинулся в класс сильной, а олово и тантал в класс со средней миграционной способностью. Не рассмотренные А.И. Перельманом элементы Sb и Hg вошли в группу, обладающих сильной миграционной способностью; $\mathrm{Ag}, \mathrm{Cr}, \mathrm{Sc}, \mathrm{Bi}$ и $\mathrm{Pb}$ в группу средней и V, La, Cd, Ga, Ge в группу слабой (см. рис. 5д). Кларк концентрации элементов в карбонатных породах относительно пород земной коры может объяснить наблюдаемые сдвиги в группах по интенсивности водной миграции, но этот вопрос требует отдельного изучения.

Второй ключевой фактор, оказывающий влияние на формирование состава природных вод Байдарской долины, связан с деятельностью человека. Для примера рассмотрим особенности состава вод четырех колодцев села Колхозное. В целом, воды характеризуются более высокой минерализацией до 1269 мг/дм ${ }^{3}$ и $\mathrm{HCO}_{3} \mathrm{Ca}, \mathrm{HCO}_{3} \mathrm{Ca}-\mathrm{Na}$ и $\mathrm{Cl}-\mathrm{HCO}_{3} \mathrm{Ca}$ составом. Изученные воды характеризуются нитратным загрязнением. Отмечается превышение предельно допустимых концентраций (ПДК) в 3-4 раза (см. табл. 1). Помимо $\mathrm{NO}_{3}{ }^{-}$отмечаются превышения ПДК по общей жесткости и содержанию лития. Отмечаются повышенные концентрации в растворе $\mathrm{Cl}^{-}, \mathrm{SO}_{4}{ }^{2-}, \mathrm{P}, \mathrm{Cu}, \mathrm{Zn}, \mathrm{As}, \mathrm{Sr}, \mathrm{Sn}, \mathrm{Ba}$ и $\mathrm{Pb}$. В изученном в 2018 и 2019 годах южном колодце села Колхозное произошло увеличение общей минерализации на 79,4 мг/дм³ и концентраций в растворе: $\mathrm{Na}, \mathrm{Mg}, \mathrm{Ca}, \mathrm{Cl}, \mathrm{Li}, \mathrm{B}, \mathrm{Si}$, Br, Sr и Ва. Также подвержены загрязнению источники и колодцы, находящиеся в других населенных пунктах (источники фонтан Варналы в селе Орлиное и Странный в селе Тыловое), а также в непосредственной близости от автодорог (колодец Ласпинской смотровой площадки) (см. табл. 1-2).

\section{Изотопный состав природных вод}


Изотопные отношения кислорода, водорода и углерода природных вод позволяют изучать их историю прямыми методами. Именно поэтому использование стабильных изотопов $\left(\delta^{18} \mathrm{O}, \delta \mathrm{D}\right.$ и $\left.\delta^{13} \mathrm{C}\right)$ завоевало широкую популярность при исследовании динамики природных вод, их генезиса и гидрогеохимических эффектов при взаимодействии воды и пород [Ферронский, Поляков, 2009]. До недавнего времени по Крыму отсутствовали систематические данные по изотопному составу атмосферных осадков и практически не проводились исследования по изотопной гидрогеохимии природных вод. Для интерпретации изотопных данных в научной литературе повсеместно используется линия Крейга - известная глобальная линия метеорных вод (Global Meteoric Water Line; GMWL) [Craig, 1961]: $\delta \mathrm{D}=8.0 \cdot \delta^{18} \mathrm{O}+10$. При определенных сочетаниях климатических и географических параметров взаимоотношение изотопов, оставаясь линейным, может отличаться от выше приведенного уравнения. Такие взаимоотношения получили название локальных линий метеорных вод (Local Meteoric Water Line; LMWL). Локальная линия метеорных вод для северного склона Крымских гор, предложенная Ю.В. Дублянским с соавторами [Дублянский и др., 2012], выражается как: $\delta \mathrm{D}=7,0 \times \delta^{18} \mathrm{O}+3,2$.

Накопление экспериментальных данных об изотопном составе подземных вод Крымского полуострова только начинается. Из рисунка 6а видно, что изотопные отношения $\delta^{18} \mathrm{O}$ и $\delta \mathrm{D}$ всех изученных водопунктов хорошо согласуются с локальной линией метеорных вод. Выделяется две группы природных вод. Первая (А) $\left(\delta^{18} \mathrm{O}=-9,9\right.$ $-8,9$ \%о и $\delta \mathrm{D}=-64,2$ - -54,0 \%о) объединяет подземные воды Родниковского водозабора, эксплуатирующего напорный водоносный комплекс верхнеюрского возраста, имеющий с ним гидравлическую взаимосвязь Скельский источник (основной), воды из пещеристочников Скельская, Черная и Мамут-Чокрак, а также ряд источников и колодцев: источник Святого Пантелеймона в с. Обороное, родник Деспита, колодец Кую-Алан и другие (см. табл. 3). При этом, по данным Ю.В. Дублянского с соавторами [Дублянский и др., 2012] воды водоносного горизонта в блоке верхнеюрских известняков, погруженном 
ниже уровня эрозионного вреза р. Краснопещерной, опробованные в наблюдательной скважине северо-восточнее Байдарской долины, имеют изотопные отношения $\delta^{18} \mathrm{O}=$ $-12,9 \pm 0,2$ \%о и $\delta \mathrm{D}=-83,0 \pm 1,0 \%$ \%.

Во второй группе (Б) представлены поверхностные воды реки Черной, Чернореченского водохранилища, озер в селах Колхозное, Гончарное и Орлиное, а также источников и колодцев: Фуска-Чокрак, Кильсе-Бурунум и других (см. табл. 3). Для нее установлены изотопные отношения: $\delta^{18} \mathrm{O}=-7,5--3,0$ \%о и $\delta \mathrm{D}=-52,0--32,5$ \%о. В целом, изученные источники и колодцы в зависимости от условий питания и степени их взаимодействия с вмещающими горными породами расположены в полях трещиннокарстовых (А) или поверхностных (Б) вод. Их характеризует очень большая вариация изотопных отношений: $\delta^{18} \mathrm{O}=-9,3--5,3$ \%о и $\delta \mathrm{D}=-61,0--39,6 \%$.

Интересно отметить, что для ряда представленных на рис. 6 данных отмечается существенное отклонение изотопного состава для пар $\delta^{18} \mathrm{O}$ и $\delta \mathrm{D}$, как от GMWL, так и от LMWL. При этом наблюдаются как положительные (то есть в сторону более «тяжелого» изотопного состава), так и отрицательные (соответственно, в сторону более «легкого» изотопного состава) отклонения от указанных линий. Однозначная интерпретация подобных эффектов требует дополнительного обширного исследования, учитывающего сезонность опробования, так называемые тайм-серии (time-serias) [Jones et al., 2003; Pan et al. 2020], и всевозможные климатические условия: температуру, влажность, наличие/отсутствие паводков и осадков [Aouade et al., 2016; Bryan et al., 2020; Soler et al., 2020]. Кроме того, построение достоверной локальной линии метеорных вод и, соответственно, корректное соотнесение получаемых данных с LMWL требует многолетних и регулярных исследований [Aouade et al., 2016], учитывающих как климатические, так и антропогенные факторы.

Тем не менее, предполагая на данном этапе исследования достоверность и ежегодную воспроизводимость данных LMWL, видно, что для некоторых поверхностных 
вод наблюдается существенные изотопные сдвиги в сторону «утяжеления» $\delta^{18} \mathrm{O}$, когда точки ложатся справа от локальной линии метеорных вод. Наиболее вероятным объяснением этого явления считается эффект испарения вод [Aouade et al., 2016; Chafouq et al. 2018; Newman et al., 2020; Yu et al., 2019], особенно активно проявляющийся в верхних слоях поверхностных вод (при глубине до 100 см), когда обогащение изотопного соотношения $\delta^{18} \mathrm{O}$ тяжелым изотопом может достигать 4 \%о [Wenninger et al., 2010]. Кроме того, нельзя исключать и вероятное обогащение вод изотопом ${ }^{18} \mathrm{O}$ при протяженном контакте вод с изотопно-тяжелыми кислород-содержащими минералами [Aydin et al., 2020; Yu et al., 2019].

Не меньший интерес вызывают данные, касающиеся вод зон региональной трещиноватости и трещинно-карстовых вод, чьи изотопные отношения $\delta^{18} \mathrm{O}$, напротив, обеднены тяжелым изотопом. Подобные негативные изотопные сдвиги в литературе [Andreo et al., 2004] связывают с проявлением эффекта сезонности. Авторы указывают на различие в емкости осадков и их изотопного состава в зависимости от времени года. Таким образом, конечный изотопный состав вод конкретного резервуара сильно зависит от того, в какой период происходит его основное питание. К аналогичным выводам пришли и авторы работы [Bagheri et al., 2019]. На основании вышеизложенного, можно сделать вывод о том, что основным периодом для питания отмеченных вод является холодное время года, когда осадки обогащены более легкими изотопами кислорода. Тем не менее, проверка данной гипотезы требует дополнительных исследований.

Помимо $\delta^{18} \mathrm{O}$ и $\delta \mathrm{D}$, в природных водах Байдарской долины было изучено распределение отношений стабильных изотопов растворенного неорганического углерода (dissolved inorganic carbon - DIC) $\delta^{13} \mathrm{C}_{\text {DIC }}$ (рис. 6б). Потенциальными источниками гидрокарбонат-иона в природных водах могут служить карбонатные осадочные породы, гидролиз алюмосиликатов, так называемый почвенный $\mathrm{CO}_{2}$, атмосферный диоксид углерода, а также органическая (биогенная) углекислота. В работах [Das et. al, 2005; 
Deirmendjian, Abril, 2018] показано, что значение $\delta^{13} \mathrm{C}_{\text {DIC }}$ определяется как типом выветриваемой (вымываемой) породы, с которой вода находится в непосредственном контакте, так и наличием/отсутствием биологической активности растений и бактерий. Первые, связывая атмосферный $\mathrm{CO}_{2}$ в ходе фотосинтеза, в дальнейшем высвобождают его уже в форме почвенной углекислоты, образуемой при корневом дыхании и жизнедеятельности микроорганизмов. При этом тип растений, осуществляющих фотосинтез, $\mathrm{C}_{3}$ или $\mathrm{C}_{4}$, также оказывает существенную роль.

Для вод Байдарской долины наиболее тяжелые значения $\delta^{13} \mathrm{C}_{\mathrm{DIC}}(-9,2--6,2$ \%о) имеют поверхностные воды, для которых протекание процессов фотосинтеза наиболее беспрепятственно. Интересно отметить, что изотопный состав этих вод очень близок с изотопным составом вторичных кальцитов $\left(\delta^{18} \mathrm{O}=-9,4--7,6\right.$ \%о и $\delta^{13} \mathrm{C}=-9,9--7,7$ \%о), что говорит об участии первых в процессах их формирования. При этом хорошо известно [Das et. al, 2005], что карбонаты континентальной коры, образованные, в основном, из морских систем, имеют значения отношений $\delta^{13} \mathrm{C}$ близкие к нулю. Для исследованного региона установлено [Рудько и др., 2017], что значения $\delta^{13} \mathrm{C}$ не зависят от фациальных особенностей и уменьшаются (от +3,0 - +3,5 \%о до $+1,0-+1,5$ \%) по мере омоложения возраста карбонатных отложений, что соответствует общему тренду позднеюрского времени. Значения $\delta^{13} \mathrm{C}$, полученные для Крымской карбонатной платформы, оказались выше (на 0,5-1 \%о) значений, характерных для глубоководных морских обстановок западной окраины Тетиса. Предполагается, что эти различия обусловлены особенностями водной циркуляции и повышенной биопродуктивностью морских акваторий Северного Перитетиса. Наши исследования водовмещающих карбонатных пород показывают значения $\delta^{13} \mathrm{C}$ в диапазоне $+1,9-+2,9$ \%. Согласно [Das et. al, 2005], выветривание подобных карбонатов (со значениями $\delta^{13} \mathrm{C} \sim 0$ \%о) с участием $\mathrm{CO}_{2}$, производимым растениями типа С должно приводить, в результате смешивания углекислоты источников, к значениям $\delta^{13} C_{\text {DIC }}$ равным -9,6 \%о, что очень близко к полученным данным. Небольшое 
«утяжеление» изотопных отношений до -6,2 \%о в некоторых образцах, по-видимому, указывает на внесение вклада в изотопный состав как атмосферного $\mathrm{CO}_{2}$ (включая процессы испарения и дегазации вод), что, согласно работе [Mickler et al., 2019] может существенно «утяжелить» изотопное отношение углерода, так и углекислоты, высвобождаемой из растений типа $\mathrm{C}_{4}$, смещающей изотопное отношение $\delta^{13} \mathrm{C}_{\text {DIC }}$ в сторону обогащения изотопом ${ }^{13} \mathrm{C}$ [Das et. al, 2005].

Трещинно-карстовые воды отличаются более легкими значениями $\delta^{13} \mathrm{C}_{\mathrm{DIC}}(-12,8$ $-11,0$ \%о). Очевидно, что в данном случае вклад атмосферного $\mathrm{CO}_{2}$, равно как и углекислоты, выделяемой растениями (ввиду невозможности фотосинтеза), в формировании изотопного состава DIC - минимально, и доминирующий в анионном составе $\mathrm{HCO}_{3}{ }^{-}-$ион обогащается «легкими» изотопами углерода из рассеянного органического вещества, попадающим в воду в виде $\mathrm{CO}_{2}$ при диагенезе и/или биологической активности гетеротрофных микроорганизмов [Deirmendjian, Abril, 2018].

Воды зоны региональной трещиноватости и трещинно-жильные (родники, колодцы) характеризуются наиболее широкой вариацией $\delta^{13} C_{D I C}(-15,5$ - $-6,9$ \%о). Основную сложность в данном случае представляет точность определения возможных источников $\mathrm{CO}_{2}$ и, соответственно, его изотопного состава. Наиболее вероятным выглядит смешанный тип «изотопного питания» DIC, включающий целый комплекс процессов: от обмена углекислотой вод с атмосферой, с одной стороны, до активного протекания процессов фотосинтеза и корневого дыхания растений, с последующим биохимическим разложения органических соединений в почвенном слое с другой. Установлено закономерное обогащение вод изотопом $\delta^{13} \mathrm{C}$ с увеличением $\mathrm{pH}$ природных вод и, напротив, смещение отношения $\delta^{13} \mathrm{C}$ в сторону легких изотопов с ростом величины общей минерализации.

\section{ЗАКЛЮЧЕНИЕ}


1) Резюмируя вышесказанное, следует отметить, что на территории Байдарской долины развиты преимущественно пресные и ультрапресные воды гидрокарбонатного кальциевого состава с величиной общей минерализации от 208 до 1269 мг/дм³. Изученные водопункты разделены на три крупные группы: поверхностные, грунтовые (зоны региональной трещиноватости и трещинно-жильные) и трещинно-карстовые. Наиболее защищенные от антропогенного влияния трещинно-карстовые имеют минерализацию (359-606 мг/дм³ ) и характеризуются в основном нейтральной величиной $\mathrm{pH}(7,4-7,9)$. Грунтовые воды отличаются более высокой минерализацией до 1269 мг/дм³ , и преимущественно слабощелочным $\mathrm{pH}=7,7$. Воды реки Черной, Чернореченского водохранилища и озер характеризуются минерализацией от 207 до 364 мг/дм ${ }^{3}$ и слабощелочной и щелочной рН $(8,0-8,9)$, что связано с широким проявлением процессов континентального засоления.

2) Изученные воды имеют интересный спектр распределения микроэлементов. Время протекания процессов взаимодействия вод с вмещающими горными породами и общие закономерности распределения элементов в земной коре определяют их концентрации в растворе. Так, наиболее распространенный в земной коре кремний в наибольшей мере накапливается в водах зоны региональной трещиноватости, где его средние концентрации составляют 4,7 мг/дм³ трещинно-карстовых - 2,23 мг/дм ${ }^{3}$ и в поверхностных - 1,18 мг/дм³ . Формирование гидрогеохимических аномалий связано с литолого-минералогическими особенностями водовмещающих пород и хозяйственной деятельностью человека, что закономерно проявляется в водопунктах, расположенных в пределах действующей сети автодорог вдоль побережья Черного моря и населенных пунктов Тыловое, Орлиное и Колхозное.

3) Установлено, что все изученные воды имеют атмосферное происхождение и располагаются вдоль глобальной (GMWL) и локальной (LMWL) линии метеорных вод. Диапазон значений $\delta^{18} \mathrm{O}$ в водах меняется от $-9,9$ до -3,3\%о с значениями $\delta \mathrm{D}$ от $-64,2$ до 
-32,5\%. Источником $\delta^{13} \mathrm{C}$ гидрокарбонат-иона в природных водах Байдарской долины служат карбонатные осадочные породы, атмосферный диоксид углерода, органические соединения и гидролиз алюмосиликатных минералов. При этом поверхностные воды имеют более тяжелый изотопный состав $\delta^{13} \mathrm{C}(-9,2--6,2 \%)$ за счет атмосферного $\mathrm{CO}_{2}$ и активной жизнедеятельности растений и микроорганизмов. Трещинно-карстовые воды отличаются более легким $\delta^{13} \mathrm{C}(-12,8--11,0 \%)$ за счет процессов взаимодействия вод с рассеянным органическим веществом. Воды зоны региональной трещиноватости и трещинно-жильные характеризуются наиболее широкой вариацией $\delta^{13} \mathrm{C}(-6,9--15,5 \%$ ), что связано со смешанным типом «изотопного питания» вод.

Исследование выполнено при поддержке РФФИ и города Севастополь в рамках гранта № 18-45-920032 p_a.

\section{СПИСОК ЛИТЕРАТУРЫ}

Амеличев Г.Н., Матюшкин Б.Э. Карст и пещеры северо-восточного обрамления Байдарской котловины (Горный Крым) // Спелеология и карстология. 2011, № 6, с. 25-35. Гидрогеология СССР. Том VIII. Крым. Гл. редактор академик А.В. Сидоренко. Москва: Издательство «Недра», 1970, 364 с.

Гидрогеология СССР. Том VIII. Крым. Гл. редактор академик А.В. Сидоренко. Москва: Издательство «Недра», 1971, 55 с.

Горобцов Д.Н., Никулина М.Е., Пендин В.В., Фоменко И.К., Козловский С.С., Черепанский М.М., Чесалов Л.Е. Оценка современного состояния месторождений подземных вод нераспределенного фонда недр Республики Крым // Геология. Инженерная геология. Гидрогеология. Геокриология. 2017, № 6, с. 8-16.

Григорьев Н.А. Распределение химических элементов в верхней части континентальной коры. Екатеринбург: УрО РАН, 2009, 383 с. 
Дублянский В.Н., Лущик А.В., Морозов В.И. Проблемы рационального использования и охраны геологической среды Крыма и прилегающих районов. Киев: ИГЛ АН УССР, 1990, 48 c.

Дублянский Ю.В., Климчук А.Б., Амеличев Г.Н., Токарев С.В., Шпётль К. Изотопный состав атмосферных осадков и карстовых источников северо-западного склона Крымских гор // Спелеология и карстология. 2012, №9, с. 14-21.

Дублянский Ю.В., Климчук А.Б., Тимохина Е.И., Амеличев Г.Н., Шпётль К. Изменение изотопного состава пород в пристеночных зонах гипогенных карстовых каналов Предгорного Крыма // Спелеология и карстология. 2013, №10, с. 58-75.

Каюкова Е.П., Юровский Ю.Г. Водные ресурсы Крыма // Геоэкология. Инженерная геология. Гидрогеология. Геокриология. 2016, № 1, с. 25-32.

Климчук А.Б., Токарев С.В. Рекомендации по охране подземных источников питьевого водоснабжения в карстовых регионах // Спелеология и карстология. 2014, № 12, с. 5-16.

Лущик А.В., Горбатюк Н.В., Морозов В.И. Водоотбор и его влияние на подземные воды пригодные для хозяйственно-питьевого водоснабжения в Крыму // Строительство и техногенная безопасность. 2016, № 12 (54), с. 83-91.

Миньковская Р.Я., Ингеров А.В. Гидрохимическая характеристика рек севастопольского региона // Экологическая безопасность прибрежной и шельфовой зон моря. 2010, № 22, с. 265-281.

Новиков Д.А., Черных А.В., Дульцев Ф.Ф. Особенности гидрогеологии верхнеюрских отложений юго-западных районов Крымского полуострова // Ученые записки Крымского федерального университета имени В. И. Вернадского. География. Геология. 2018, т. 4 (70), № 4, с. 268-288.

Новиков Д.А., Черных А.В., Дульцев Ф.Ф. Новый взгляд на гидрогеологические условия города федерального значения Севастополь // Известия Томского политехнического университета. Инжиниринг георесурсов. 2019, т. 330, № 8, с. 105-122 (а). 
Новиков Д.А., Черных А.В., Дульцев Ф.Ф. Оценка качества подземных вод верхнеюрских отложений юго-западных районов Крымского полуострова для целей питьевого и сельскохозяйственного водоснабжения // Экология и промышленность России. 2019, т. 23, № 4, с. 52-57 (б).

Основы гидрогеологии. Гидрогеохимия. Гл. редактор С.Л. Шварцев. Новосибирск: Наука, 1982, 287 c.

Парубец О.В. Изменение климата в Крыму // Ученые записки Таврического национального университета им. В.И. Вернадского. Серия: География. 2009, т. 22 (61), № 2, c. 88-96.

Перельман А.И. Геохимия ландшафта. Изд. 2-е. М.: Высшая школа, 1975, 342 с.

Приблуда В.Д., Коджаспиров А.А., Дублянский В.Н. Баланс подземных вод югозападной части Горного Крыма // Геологический журнал. 1979, т. 39, № 2, с. 38-46.

Рудько С.В. Обстановки накопления верхнеюрских отложений Байдарской котловины и эволюция Крымской карбонатной платформы // Литология и полезные ископаемые. 2018, № 4, с. 337-354.

Рудько С.В., Кузнецов А.Б., Покровский Б.Г. Sr-хемостратиграфия, $\delta 13 \mathrm{C}$ и $\delta 18 \mathrm{O}$ отложений Крымской карбонатной платформы (поздняя юра, Северный Перитетис) // Литология и полезные ископаемые. 2017, № 6, с. 58-77.

Тарасенко В.С., Паштецкий В.С., Ляшевский В.И., Панютин В.М., Резников С.В., Тимченко 3.В. Экологические проблемы водохозяйственного комплекса Украины и Крыма // Таврійський вісник аграрної науки. 2013, № 1, с. 115-119.

Ферронский В.И., Поляков В.А. Изотопия гидросферы. Москва: Научный мир, 2009, 632 C.

Шварцев С.Л. Общая гидрогеология. М.: Недра, 1996, 423 с. 
Шестопалов В.М., Богуславский А.С., Бублясь В.Н. Оценка защищенности и уязвимости подземных вод с учетом зон быстрой миграции. Киев: Институт геологических наук НАН Украины, 2007, 120 с.

Andreo B., Linan C., Carrasco F., Jimenez de Cisneros C., Caballero F., Mudry J. Influence of rainfall quantity on the isotopic composition $(18 \mathrm{O}$ and $2 \mathrm{H})$ of water in mountainous areas. Application for groundwater research in the Yunquera-Nieves karst aquifers (S Spain) // Applied Geochemistry. 2004. v. 19, pp. 561-574.

Aouade G., Ezzahar J., Amenzou N., Er-Raki S., Benkaddour A., Khabba S., Jarlan L. Combining stable isotopes, Eddy Covariance system and meteorological measurements for partitioning evapotranspiration, of winter wheat, into soil evaporation and plant transpiration in a semi-arid region // Agricultural Water Management. 2016. v. 177, pp. 181-192.

Aydin H., Karakus H., Multu H. Hydrogeochemistry of geothermal waters in eastern Turkey: Geochemical and isotopic constraints on water-rock interaction // Journal of Volcanology and Geothermal Research. 2020. v. 390, article 106708. 18 pp.

Bagheri R., Bagheri F., Karami G. H., Jafari H. Chemo-isotopes (18O \& 2H) signatures and HYSPLIT model application: Clues to the atmospheric moisture and air mass origins // Atmospheric Environment. 2019. v. 215. article 116892. 11 p.

Bryan E., Meredith K.T., Baker A., Andersen M.S., Post V.E.A. Treble P.C. How water isotopes $\left({ }^{18} \mathrm{O},{ }^{2} \mathrm{H},{ }^{3} \mathrm{H}\right)$ within an island freshwater lens respond to changes in rainfall // Water research. 2020. v. 170, article 115301. 11 p.

Chafouq D., Mandour A.El, Elgettafi M., Himi M., Chouikri I., Casas A. Hydrochemical and isotopic characterization of groundwater in the Ghis-Nekor plain (northern Morocco) // Journal of African Earth Sciences. 2018. v. 139, pp. 1-13.

Coplen T.B. Normalization of oxygen and hydrogen isotope data // Chemical Geology (Isotope Geoscience Section). 1988, v. 12, pp. 293-297.

Craig H. Isotopic variations in meteoric waters // Science. 1961, v. 133, pp. 1702-1703. 
Das A., Krishnaswami S., Bhattacharya S.K. Carbon isotope ratio of dissolved inorganic carbon (DIC) in rivers draining the Deccan Traps, India: Sources of DIC and their magnitudes // Earth and Planetary Science Letters. 2005, v. 236, pp. 419-429.

Deirmendjian L., Abril G. Carbon dioxide degassing at the groundwater-stream-atmosphere interface: isotopic equilibration and hydrological mass balance in a sandy watershed // Journal of Hydrology. 2018, v. 558, pp. 129-143.

Epstein S., Mayeda T. Variation of O18 content of waters from natural sources / Geoch. Et Cosmoch. Acta. 1953, v. 4, pp. 213-224.

Handbook of Stable Isotope Analytical Techniques, Volume 1. Elsevier B.V, 2004, 1258 p.

Jones I.C., Banner J.L. Estimating recharge thresholds in tropical karst island aquifers: Barbados, Puerto Rico and Guam // Journal of Hydrology. 2003. v. 278, pp. 131-143.

Mickler P.J., Carlson P., Banner J.L., Breecker D.O., Stern L., Guilfoyle A. Quantifying carbon isotope disequilibrium during in-cave evolution of drip water along discreet flow paths // Geochimica et Cosmochimica Acta. 2019, v. 244, pp. 182-196.

Nelson S.T. A simple, practical methodology for routine VSMOW/SLAP normalization of water samples analyzed by continuous flow methods // Rapid Commun. Mass Spectrom. 2000, v. 14, pp. 1044-1046.

Newman C.P. Poulson S.R., Hanna B. Regional isotopic investigation of evaporation and water-rock interaction in mine pit lakes in Nevada, USA // Journal of Geochemical Exploration. 2020. v. 210. article 106445,15 p.

Nichkova L.A., Novikov D.A., Chernykh A.V., Dultsev F.F., Sigora G.A., Khomenko T. Yu. Geochemistry of natural waters of the Baydar valley (Crimean Peninsula) // E3S Web of Conferences. 2019, v. 98, № 01036.

Novikov D.A., Nichkova L.A., Chernykh A.V., Dultsev F.F., Pyryaev A.N., Sigora G.A., Khomenko T. Yu. Distribution of the stable isotopes ( $\delta 180, \delta \mathrm{D}$ и $\delta 13 \mathrm{C})$ in natural waters of the Baydar valley (Crimean Peninsula) // E3S Web of Conferences. 2019, v. 98, № 01038. 
Pan Y.-X., Wang X.-P., Ma X.-Z., Zhang Y.-F., Hu R. The stable isotopic composition variation characteristics of desert plants and water sources in an artificial revegetation ecosystem in Northwest China // Catena. 2020. v. 189, article 104499, pp. 1-10.

Raftery A.E., Zimmer A., Frierson D.M.V., Startz R., Liu P. Less than $2^{\circ} \mathrm{C}$ warming by 2100 unlikely // Nature Climate Change. 2017, v. 7, pp. 637-641.

Soler A., Bonotto D.M. Stable isotopes (H, O, S) signatures evidencing evolutionary trends of Brazilian spas groundwaters // Journal of Geochemical Exploration. 2020. v. 210, article 106452. pp. 1-13.

Wenninger J., Beza D.T., Uhlenbrook S. Experimental investigations of water fluxes within the soil-vegetation-atmosphere system: Stable isotope mass-balance approach to partition evaporation and transpiration // Physics and Chemistry of the Earth. 2010. v. 35, p. 565-570.

Worthington S.R.H., Ford D.C., Beddows P. Porosity and permeability enhancement in unconfined carbonate aquifers as a result of solution // Speleogenesis: Evolution of Karst Aquifers. 2000, pp. 423-432.

Yano K., Sekiya N., Samson B.K., Mazid M.A., Yamauchi A., Kono Y., Wade L.J. Hydrogen isotope composition of soil water above and below the hardpan in a rainfed lowland rice field // Field Crops Research. 2006, v. 96, pp. 477-480.

Yu H., Ma T., Du Y. Chen L. Genesis of formation water in the northern sedimentary basin of South China Sea: Clues from hydrochemistry and stable isotopes (D, ${ }^{18} \mathrm{O},{ }^{37} \mathrm{Cl}$ and $\left.{ }^{81} \mathrm{Br}\right) / /$ Journal of Geochemical Exploration. 2019. v. 196, pp. 57-65. 
Рис. 1. Местоположение изученных водопунктов (1-30) в пределах Байдарской долины и ее горного обрамления.

Водоносный комплекс: 1 - плиоценовых и четвертичных отложений, 2 - миоценовых отложений, 3 - верхнемеловых отложений, 4 - нижнемеловых отложений, 5 верхнеюрских отложений, 6 - верхнетриасово-среднеюрских отложений; 7 - граница Севастопольской городской агломерации; 8 - автодорога Ялта - Севастополь (Н19); 9 проявления марганцевых руд; 10 - Воды зоны региональной трещиноватости карбонатно-терригенных пород, подверженные процессам континентального засоления (I групnа): 1 - колодец Кильсе-Буруном; 2 - колодец Q-044; 3 - колодец Чертова лестница; 4 - источник Деспит; 5 - колодец Кую-Алан, 11 - Воды зоны региональной трещиноватости выщелачивания алюмосиликатов и окисления сульфидов (II группа): 6 колодец Фуска-Чокрак; 7 - южный колодец, с. Колхозное, 12 - Воды зоны региональной трещиноватости преимущественно натриевых алюмосиликатов (длительного взаимодействия в системе вода - порода), подверженные процессам континентального засоления (III групnа): 8 - источник Фонтан Варналы; 9 - источник Кара-Агач; 10 источник Св. Пантелеймона, 13 - Воды зоны региональной трещиноватости преимущественно натриевых алюмосиликатов, подверженные процессам континентального засоления в условиях антропогенного влияния (IV группа): 11 северный колодец, с. Колхозное; 12 - колодец центральный 1, с. Колхозное; 13 - колодец центральный 2, с. Колхозное; 14 - колодец возле Ласпинской смотровой площадки, 14 Трещинно-жильные воды выщелачивания натриевых алюмосиликатов и окисления сульфидов (V групnа): 15 - источник Странный; 16 - источник Мердвен-Каясы, 15 Трещинно-жильные воды выщелачивания натриевых алюмосиликатов (длительного взаимодействия в системе вода - порода) (VI групnа): 17 - колодец Санаторное верхний; 18 - колодец Санаторное нижний; 16 - Трещинно-карстовые воды (VII групnа): 19 - 5760; 20 - 5775; 21 - 5776; 22 - 5531; 23 - 5566; 24 - 5595; 25 - источник Скельский основной, 17 - Поверхностные воды, подверженные влиянию процессов континентального засоления (VIII групnа): 26 - оз. Конюшня в с. Орлиное; 27 - озеро в с. Гончарное; 28 озеро Узужинское, с. Колхозное; 29 - Чернореченское водохранилище; 30 - река Черная.

\section{Рис. 2. Схема гидрогеологической стратификации Севастопольской городской агломерации [Новиков и др., 2019а].}

В/н г. - водоносный горизонт, в/п г. - водоупорный горизонт.

Рис. 3. Диаграмма Пайпера состава природных вод Байдарской долины (а), зависимости величины рН (б) и содержания растворенного кислорода (в) от величины общей минерализации природных вод.

Типы вод: 1 - поверхностные, 2 - трещинно-карстовые, 3 - Скельский источник, 4 - зоны региональной трещиноватости, 5 - трещинно-жильные.

Рис. 4. Зависимость содержаний основных катионов (а) и анионов (б) от общей минерализации природных вод Байдарской долины.

Условные обозначения см. рис. 3. 
Рис. 5. Спектр распределения микроэлементов в природных водах Байдарской долины (а); зависимость содержаний кремния и стронция (б), бора и брома (в), лития и скандия (г) от величины общей минерализации природных вод; ряды миграции микроэлементов в природных водах Байдарской долины.

Типы вод: 1 - трещинно-карстовые, 2 - зоны региональной трещиноватости и трещинножильные, 3 - поверхностные; 4 - гидрогеохимический фон. Остальные условные обозначения см. рис. 3.

Рис. 6. Изотопный состав $\delta D$ и $\delta^{18} O$ (а) и $\delta^{13} C$ и $\delta^{18} O$ (б) в природных водах Байдарской долины.

пещер-источников [Дублянский и др., 2012]: 1 - Скельская и Черная, 2 - Мамут-Чокрак; 3 - вторичных кальцитов пещеры Беш-Кош [Дублянский и др., 2013]. GMWL [Craig, 1961], LMWL [Дублянский и др., 2012]. Остальные условные обозначения см. рис. 3. 
Химический состав природных вод Байдарской долины

\begin{tabular}{|c|c|c|c|c|c|c|c|c|c|c|c|c|c|c|c|c|c|c|}
\hline \multirow{2}{*}{$\begin{array}{c}\text { № на рис. } \\
1\end{array}$} & \multicolumn{2}{|c|}{ Координаты } & \multirow{2}{*}{$\begin{array}{c}\text { Абс. } \\
\text { отметка, м }\end{array}$} & \multirow{2}{*}{ Год } & \multirow{2}{*}{$\begin{array}{l}\mathrm{p} \\
\mathrm{H}\end{array}$} & \multirow{2}{*}{ Eh } & \multirow{2}{*}{$\mathrm{O}_{2}$, мг/дм³ } & \multicolumn{9}{|c|}{ Элементы, мг/дм ${ }^{3}$} & \multirow{2}{*}{$\begin{array}{c}\mathrm{M}, \\
\mathrm{M \Gamma} / \mathrm{дM}^{3}\end{array}$} & \multirow{2}{*}{ Химический тип ${ }^{* *}$} \\
\hline & шир. N & долг. Е & & & & & & $\mathrm{Ca}^{2+}$ & $\mathrm{Mg}^{2+}$ & $\mathrm{Na}^{+}$ & $\mathrm{K}^{+}$ & $\mathrm{HCO}_{3}^{-}$ & $\mathrm{SO}_{4}^{2-}$ & $\mathrm{Cl}^{-}$ & $\mathrm{NO}_{3}$ & Si & & \\
\hline 1 & 2 & 3 & 4 & 5 & 6 & 7 & 8 & 9 & 10 & 11 & 12 & 13 & 14 & 15 & 16 & 17 & 18 & 19 \\
\hline \multicolumn{19}{|c|}{ Воды зоны региональной трещиноватости карбонатно-терригенных пород, подверженные процессам континентального засоления (I группа) } \\
\hline 1 & $44^{\circ} 24^{\prime} 40$ & $33^{\circ} 49^{\prime} 60$ & +358 & 2018 & $\begin{array}{c}8, \\
1\end{array}$ & - & - & 50,7 & 3,4 & 7,3 & $\begin{array}{c}10,5 \\
0\end{array}$ & 177 & 8,8 & 10,9 & 1,7 & $\begin{array}{c}3,1 \\
6 \\
\end{array}$ & 269 & $\mathrm{HCO}_{3} \mathrm{Ca}$ \\
\hline 1 & $44^{\circ} 24^{\prime} 40$ & $33^{\circ} 49^{\prime} 60$ & +358 & 2019 & $\begin{array}{l}7 \\
5\end{array}$ & $\begin{array}{c}147, \\
0\end{array}$ & 3,19 & 90,0 & 5,8 & 12,4 & 1,70 & 285 & 15,0 & 19,8 & 6,4 & $\begin{array}{c}3,7 \\
5\end{array}$ & 436 & $\mathrm{HCO}_{3} \mathrm{Ca}$ \\
\hline 2 & $44^{\circ} 25^{\prime} 10$ & $33^{\circ} 51^{\prime \prime} 50$ & +363 & 2018 & $\begin{array}{l}7, \\
9\end{array}$ & - & - & $\begin{array}{c}100, \\
1\end{array}$ & 4,0 & 12,3 & 0,45 & 311 & 25,2 & 14,6 & 2,1 & 3,11 & 468 & $\mathrm{HCO}_{3} \mathrm{Ca}$ \\
\hline 2 & $44^{\circ} 25^{\prime} 10$ & $33^{\circ} 51^{\prime} 50$ & +363 & 2019 & $\begin{array}{l}7 \\
9 \\
\end{array}$ & 67,2 & - & 98,0 & 9,8 & 16,2 & 0,38 & 317 & 25,9 & 19,3 & 0,3 & $\begin{array}{c}3,6 \\
9\end{array}$ & 487 & $\mathrm{HCO}_{3} \mathrm{Ca}-\mathrm{Mg}-\mathrm{Na}$ \\
\hline 3 & $44^{\circ} 25^{\prime} 30$ & $33^{\circ} 51^{\prime \prime} 05$ & +611 & 2018 & $\begin{array}{l}7 \\
3\end{array}$ & - & - & $\begin{array}{c}137, \\
0\end{array}$ & 14,8 & 24,3 & 0,94 & 471 & 26,0 & 30,8 & 3,1 & $\begin{array}{c}5,9 \\
4\end{array}$ & 705 & $\mathrm{HCO}_{3} \mathrm{Ca}-\mathrm{Mg}-\mathrm{Na}$ \\
\hline 3 & $44^{\circ} 25^{\prime \prime} 30$ & $33^{\circ} 51^{\prime} 05$ & +611 & 2019 & $\begin{array}{l}7 \\
3 \\
\end{array}$ & $\begin{array}{c}145, \\
2 \\
\end{array}$ & 8,85 & $\begin{array}{c}140, \\
0\end{array}$ & 18,3 & 21,7 & 0,86 & 460 & 25,6 & 48,7 & 0,6 & $\begin{array}{c}5,9 \\
7 \\
\end{array}$ & 716 & $\mathrm{HCO}_{3}-\mathrm{Cl} \mathrm{Ca}-\mathrm{Mg}$ \\
\hline 4 & $44^{\circ} 25^{\prime} 20$ & $33^{\circ} 47^{\prime} 05$ & +522 & 2018 & $\begin{array}{l}7 \\
4\end{array}$ & - & - & $\begin{array}{c}133 \\
0\end{array}$ & 18,2 & 14,4 & 0,71 & 470 & 27,8 & 19,0 & 3,8 & $\begin{array}{c}4,2 \\
4\end{array}$ & 683 & $\mathrm{HCO}_{3} \mathrm{Ca}-\mathrm{Mg}$ \\
\hline 4 & $44^{\circ} 25^{\prime} 20$ & $33^{\circ} 47^{\prime \prime} 05$ & +522 & 2019 & $\begin{array}{l}7, \\
4\end{array}$ & $\begin{array}{c}136, \\
5\end{array}$ & - & $\begin{array}{c}107 \\
0\end{array}$ & 23,0 & 16,3 & 0,67 & 401 & 27,9 & 23,2 & 5,9 & $\begin{array}{c}5,5 \\
8\end{array}$ & 605 & $\mathrm{HCO}_{3}$ Ca-Mg \\
\hline 5 & $44^{\circ} 25^{\prime \prime} 15$ & $33^{\circ} 50^{\prime} 40$ & +577 & $\begin{array}{c}2018 \\
*\end{array}$ & $\begin{array}{l}7 \\
9\end{array}$ & - & - & 115,0 & 6,5 & 10,9 & 0,49 & 334 & 31,8 & 22,4 & 2,1 & $\begin{array}{c}3,6 \\
3\end{array}$ & 521 & $\mathrm{HCO}_{3} \mathrm{Ca}$ \\
\hline \multicolumn{5}{|c|}{ Среднее значение: } & $\begin{array}{l}7, \\
6\end{array}$ & $\begin{array}{c}124, \\
0\end{array}$ & 6,02 & $\begin{array}{c}107, \\
9\end{array}$ & 11,5 & 15,1 & 1,86 & 358 & 23,8 & 23,2 & 2,9 & $\begin{array}{c}4,3 \\
4\end{array}$ & 543 & - \\
\hline \multicolumn{19}{|c|}{ Воды зоны региональной трещиноватости выщелачивания алюмосиликатов и окисления сульфидов (II группа) } \\
\hline 6 & $44^{\circ} 26^{\prime \prime} 30$ & $33^{\circ} 45^{\prime} 60$ & +263 & 2018 & $\begin{array}{l}7 \\
8\end{array}$ & - & - & 88,0 & 8,8 & 10,2 & 0,53 & 273 & 33,6 & 14,8 & 2,2 & $\begin{array}{c}2,8 \\
5\end{array}$ & 429 & $\mathrm{HCO}_{3}-\mathrm{SO}_{4} \mathrm{Ca}-\mathrm{Mg}$ \\
\hline 6 & $44^{\circ} 26^{\prime \prime} 30$ & $33^{\circ} 45^{\prime} 60$ & +263 & 2019 & $\begin{array}{l}7, \\
4\end{array}$ & $\begin{array}{c}172 \\
1 \\
\end{array}$ & 5,61 & 98,0 & 15,3 & 14,2 & 0,33 & 347 & 28,1 & 17,5 & 2,0 & $\begin{array}{c}3,8 \\
7 \\
\end{array}$ & 520 & $\mathrm{HCO}_{3} \mathrm{Ca}-\mathrm{Mg}$ \\
\hline 7 & $44^{\circ} 28^{\prime} 20$ & $33^{\circ} 52^{\prime} 50$ & +362 & 2018 & $\begin{array}{l}7, \\
4\end{array}$ & - & - & $\begin{array}{c}102, \\
5\end{array}$ & 6,7 & 13,1 & 1,24 & 354 & 13,2 & 6,5 & 2,4 & $\begin{array}{c}4,8 \\
9 \\
\end{array}$ & 497 & $\mathrm{HCO}_{3} \mathrm{Ca}$ \\
\hline 7 & $44^{\circ} 28^{\prime} 20$ & $33^{\circ} 52^{\prime} 50$ & +362 & 2019 & $\begin{array}{l}7, \\
4\end{array}$ & $\begin{array}{c}173 \\
0\end{array}$ & 5,61 & 114,0 & 8,5 & 19,5 & 0,94 & 411 & 14,8 & 7,9 & 2,2 & $\begin{array}{c}5,6 \\
0\end{array}$ & 577 & $\mathrm{HCO}_{3} \mathrm{Ca}-\mathrm{Na}$ \\
\hline \multicolumn{5}{|c|}{ Среднее значение: } & $\begin{array}{l}7, \\
5 \\
\end{array}$ & $\begin{array}{c}172, \\
6\end{array}$ & 5,61 & $\begin{array}{c}100, \\
6\end{array}$ & 9,8 & 14,3 & 0,76 & 346 & 22,4 & 11,7 & 2,2 & $\begin{array}{c}4,3 \\
0\end{array}$ & 506 & - \\
\hline \multicolumn{19}{|c|}{$\begin{array}{r}\text { Воды зоны региональной трещиноватости преимущественно натриевых алюмосиликатов (длительного взаимодействия в системе вода - порода), } \\
\text { подверженные процессам континентального засоления (III группа) }\end{array}$} \\
\hline 8 & $44^{\circ} 27^{\prime \prime} 55$ & $33^{\circ} 41^{\prime} 50$ & +137 & 2018 & $\begin{array}{c}7, \\
1\end{array}$ & $\begin{array}{c}209 \\
3\end{array}$ & 3,79 & $\begin{array}{c}137, \\
0\end{array}$ & 19,0 & 36,8 & 9,70 & 420 & 59,0 & 52,7 & 1,5 & $\begin{array}{c}6,1 \\
5\end{array}$ & 774 & $\mathrm{HCO}_{3}-\mathrm{Cl} \mathrm{Ca}-\mathrm{Na}-\mathrm{Mg}$ \\
\hline 8 & $44^{\circ} 27^{\prime} 55$ & $33^{\circ} 41^{\prime} 50$ & +137 & 2019 & 7 & - & - & 123, & 11,7 & 30,7 & 4,73 & 427 & 34,6 & 31,4 & 40,1 & 5,8 & 664 & $\mathrm{HCO}_{3}$-Cl-SO ${ }_{4} \mathrm{Ca}-\mathrm{Na}-\mathrm{Mg}$ \\
\hline
\end{tabular}




\begin{tabular}{|c|c|c|c|c|c|c|c|c|c|c|c|c|c|c|c|c|c|c|}
\hline & $"$ & $"$ & & & 1 & & & 8 & & & & & & & & 0 & & \\
\hline 9 & $44^{\circ} 26^{\prime} 40$ & $33^{\circ} 46^{\prime} 25$ & +138 & $\begin{array}{c}2018 \\
*\end{array}$ & $\begin{array}{l}7 \\
7\end{array}$ & - & - & $\begin{array}{c}105 \\
3\end{array}$ & 9,8 & 27,4 & $\begin{array}{c}16,2 \\
6\end{array}$ & 366 & 39,3 & 29,5 & 4,2 & $\begin{array}{c}4,5 \\
4\end{array}$ & 594 & $\mathrm{HCO}_{3}-\mathrm{Cl}-\mathrm{SO}_{4} \mathrm{Ca}-\mathrm{Na}-\mathrm{Mg}$ \\
\hline 10 & $44^{\circ} 30^{\prime} 60$ & $33^{\circ} 38^{\prime} 60$ & +177 & 2019 & $\begin{array}{l}7 \\
2\end{array}$ & $\begin{array}{c}185 \\
4\end{array}$ & 9,80 & 98,0 & 24,0 & 23,8 & 0,32 & 406 & 27,0 & 23,5 & 2,2 & \begin{tabular}{c|c}
6,1 \\
2
\end{tabular} & 605 & $\mathrm{HCO}_{3} \mathrm{Ca}-\mathrm{Mg}-\mathrm{Na}$ \\
\hline \multicolumn{5}{|c|}{ Среднее значение: } & 7, & $\begin{array}{c}197 \\
4\end{array}$ & 6,80 & 116,0 & 16,1 & 29,7 & 7,75 & 405 & 40,0 & 34,3 & 12,0 & $\begin{array}{c}5,6 \\
5\end{array}$ & 659 & - \\
\hline \multicolumn{19}{|c|}{$\begin{array}{c}\text { Воды зоны региональной трещиноватости преимущественно натриевых алюмосиликатов, подверженные процессам } \\
\text { континентального засоления в условиях антропогенного влияния (IV группа) }\end{array}$} \\
\hline 11 & $44^{\circ} 28^{\prime \prime} 30$ & $33^{\circ} 52^{\prime} 55$ & +364 & $\begin{array}{c}2018 \\
*\end{array}$ & $\begin{array}{c}8, \\
5\end{array}$ & - & - & $\begin{array}{c}101 \\
0\end{array}$ & 7,8 & 44,7 & 3,87 & 360 & 45,1 & 29,9 & 3,6 & 4,11 & 592 & $\mathrm{HCO}_{3}-\mathrm{SO}_{4}-\mathrm{Cl} \mathrm{Ca-Na}$ \\
\hline 12 & $44^{\circ} 28^{\prime} 25$ & $33^{\circ} 52^{\prime} 50$ & +372 & 2019 & $\begin{array}{l}7 \\
2 \\
\end{array}$ & $\begin{array}{c}154 \\
5\end{array}$ & 3,79 & $\begin{array}{c}157 \\
0\end{array}$ & 33,0 & 117,0 & $\begin{array}{c}49,8 \\
0 \\
\end{array}$ & 537 & 111,0 & $\begin{array}{c}127 \\
0\end{array}$ & $\begin{array}{c}137, \\
0\end{array}$ & $\begin{array}{c}6,2 \\
8 \\
\end{array}$ & 1269 & $\mathrm{HCO}_{3}-\mathrm{Cl}-\mathrm{SO}_{4} \mathrm{Ca}-\mathrm{Na}-\mathrm{Mg}$ \\
\hline 13 & $44^{\circ} 28^{\prime} 25$ & $33^{\circ} 52^{\prime} 55$ & +371 & 2019 & $\begin{array}{l}7 \\
4 \\
\end{array}$ & $\begin{array}{c}171 \\
8\end{array}$ & 3,99 & $\begin{array}{c}164 \\
0\end{array}$ & 39,0 & 70,1 & 0,45 & 291 & 58,0 & $\begin{array}{c}197 \\
0\end{array}$ & $\begin{array}{c}180 \\
0\end{array}$ & $\begin{array}{c}6,2 \\
1 \\
\end{array}$ & 1000 & Cl-HCO ${ }_{3}$ Ca-Mg-Na \\
\hline 14 & $44^{\circ} 25^{\prime} 50$ & $33^{\circ} 42^{\prime} 30$ & +302 & $\begin{array}{c}2018 \\
*\end{array}$ & $\begin{array}{c}8 \\
3\end{array}$ & - & - & $\begin{array}{c}103 \\
8\end{array}$ & 12,9 & 82,9 & 2,47 & 226 & $\begin{array}{c}183 \\
0\end{array}$ & 85,7 & 1,5 & $\begin{array}{c}3,2 \\
6\end{array}$ & 697 & $\mathrm{SO}_{4}-\mathrm{HCO}_{3}-\mathrm{Cl} \mathrm{Ca}-\mathrm{Na}-\mathrm{Mg}$ \\
\hline \multicolumn{5}{|c|}{ Среднее значение: } & $\begin{array}{l}7, \\
9\end{array}$ & $\begin{array}{c}163 \\
2\end{array}$ & 3,89 & $\begin{array}{c}131 \\
5\end{array}$ & 23,2 & $\mathbf{7 8 , 7}$ & $\begin{array}{c}14,1 \\
5\end{array}$ & 354 & 99,3 & $\begin{array}{c}109 \\
9\end{array}$ & 80,5 & $\begin{array}{c}4,9 \\
7\end{array}$ & 890 & - \\
\hline \multicolumn{19}{|c|}{ Трещинно-жильные воды выщелачивания натриевых алюмосиликатов и окисления сульфидов (V группа) } \\
\hline 15 & $44^{\circ} 26^{\prime} 30$ & $33^{\circ} 43^{\prime} 20$ & +304 & $\begin{array}{c}2018 \\
*\end{array}$ & $\begin{array}{c}7 \\
9\end{array}$ & - & - & $\begin{array}{c}141 \\
0\end{array}$ & 14,6 & 21,2 & 1,09 & 301 & $\begin{array}{c}170 \\
0\end{array}$ & 25,9 & 2,0 & $\begin{array}{c}4,2 \\
9\end{array}$ & 675 & $\mathrm{HCO}_{3}-\mathrm{SO}_{4} \mathrm{Ca}-\mathrm{Mg}-\mathrm{Na}$ \\
\hline 16 & $44^{\circ} 25^{\prime} 05$ & $33^{\circ} 52^{\prime} 55$ & +400 & $\begin{array}{c}2018 \\
*\end{array}$ & $\begin{array}{c}8, \\
6\end{array}$ & - & - & 44,0 & 6,8 & 13,5 & 1,03 & 128 & 53,1 & 6,6 & 0,7 & $\begin{array}{c}1,5 \\
0\end{array}$ & 253 & $\mathrm{HCO}_{3}-\mathrm{SO}_{4} \mathrm{Ca}-\mathrm{Mg}-\mathrm{Na}$ \\
\hline \multicolumn{5}{|c|}{ Среднее значение: } & $\begin{array}{l}8 \\
3\end{array}$ & & & 92,5 & 10,7 & 17,4 & 1,06 & 215 & 111,6 & 16,3 & 1,4 & $\begin{array}{c}2,9 \\
0\end{array}$ & 464 & - \\
\hline \multicolumn{19}{|c|}{ Трещинно-жильные воды выщелачивания натриевых алюмосиликатов (длительного взаимодействия в системе вода - порода) (VI группа) } \\
\hline 17 & $44^{\circ} 24^{\prime} 15$ & $33^{\circ} 49^{\prime \prime} 20$ & +192 & 2018 & $\begin{array}{l}7, \\
2\end{array}$ & - & - & 117,0 & 17,6 & 23,0 & 1,59 & 466 & 5,6 & 20,4 & 3,3 & $\begin{array}{c}4,7 \\
4\end{array}$ & 651 & $\mathrm{HCO}_{3}-\mathrm{Cl} \mathrm{Ca}-\mathrm{Mg}-\mathrm{Na}$ \\
\hline 17 & $44^{\circ} 24^{\prime} 15$ & $33^{\circ} 49^{\prime} 20$ & +192 & 2019 & $\begin{array}{l}7, \\
2\end{array}$ & 110,2 & 5,90 & 98,0 & 19,5 & 22,4 & 1,40 & 403 & 6,9 & 23,0 & 0,5 & $\begin{array}{c}6,5 \\
6\end{array}$ & 575 & $\mathrm{HCO}_{3}-\mathrm{Cl} \mathrm{Ca}-\mathrm{Mg}-\mathrm{Na}$ \\
\hline 18 & $44^{\circ} 24^{\prime} 10$ & $33^{\circ} 49^{\prime \prime} 20$ & +143 & $\begin{array}{c}2018 \\
*\end{array}$ & $\begin{array}{l}7, \\
6\end{array}$ & - & - & $\begin{array}{c}143 \\
0\end{array}$ & 18,7 & 25,7 & 1,32 & 493 & 16,0 & 48,6 & 2,9 & $\begin{array}{c}5,9 \\
4\end{array}$ & 746 & $\mathrm{HCO}_{3}-\mathrm{Cl} \mathrm{Ca}-\mathrm{Mg}-\mathrm{Na}$ \\
\hline \multicolumn{5}{|c|}{ Среднее значение: } & $\begin{array}{l}7, \\
3\end{array}$ & 110,2 & 5,90 & 119,3 & 18,6 & 23,7 & 1,44 & 454 & 9,5 & 30,7 & 2,2 & $\begin{array}{c}5,7 \\
5 \\
\end{array}$ & 657 & - \\
\hline \multicolumn{19}{|c|}{ Трещинно-карстовые воды (VII группа) } \\
\hline 19 & $44^{\circ} 27^{\prime} 60$ & $33^{\circ} 51^{\prime} 25$ & -77 & 2018 & $\begin{array}{c}8, \\
0\end{array}$ & - & - & $\begin{array}{c}107 \\
0\end{array}$ & 5,0 & 4,2 & 0,5 & 348 & 7,0 & 4,7 & 2,6 & $\begin{array}{c}2,1 \\
7\end{array}$ & 476 & $\mathrm{HCO}_{3} \mathrm{Ca}$ \\
\hline 20 & $44^{\circ} 28^{\prime} 30$ & $33^{\circ} 51^{\prime} 00$ & -539 & 2018 & $\begin{array}{c}7, \\
9\end{array}$ & - & - & 93,0 & 5,6 & 4,5 & 0,50 & 303 & 9,7 & 5,2 & 2,6 & $\begin{array}{c}2,4 \\
0\end{array}$ & 422 & $\mathrm{HCO}_{3} \mathrm{Ca}$ \\
\hline 21 & $44^{\circ} 28^{\prime} 40$ & $33^{\circ} 50^{\prime} 60$ & -539 & 2018 & $\begin{array}{l}8, \\
2\end{array}$ & - & - & $\begin{array}{c}139 \\
0\end{array}$ & 5,3 & 4,7 & 0,60 & 441 & 10,2 & 5,4 & 2,8 & $\begin{array}{c}2,2 \\
1\end{array}$ & 606 & $\mathrm{HCO}_{3} \mathrm{Ca}$ \\
\hline 22 & $44^{\circ} 27^{\prime} 55$ & $33^{\circ} 51^{\prime} 20$ & -997 & 2018 & 8, & - & - & 83,3 & 2,8 & 2,2 & 0,38 & 262 & 5,6 & 3,0 & 2,5 & 1,4 & 359 & $\mathrm{HCO}_{3} \mathrm{Ca}$ \\
\hline
\end{tabular}




\begin{tabular}{|c|c|c|c|c|c|c|c|c|c|c|c|c|c|c|c|c|c|c|}
\hline & & & & & 2 & & & & & & & & & & & 2 & & \\
\hline 23 & $44^{\circ} 27^{\prime} 60$ & $33^{\circ} 51^{\prime} 05$ & -352 & 2018 & $\begin{array}{l}7 \\
9\end{array}$ & - & - & 9,0 & 7,8 & 6,2 & 0,64 & 311 & 9,4 & 5,2 & 2,5 & $\begin{array}{c}3,0 \\
3\end{array}$ & 430 & $\mathrm{HCO}_{3} \mathrm{Ca}-\mathrm{Mg}$ \\
\hline 23 & $44^{\circ} 27^{\prime} 60$ & $33^{\circ} 51^{\prime} 05$ & -352 & 2019 & $\begin{array}{l}7 \\
4\end{array}$ & 118,7 & 8,29 & 86,0 & 8,5 & 5,1 & 0,34 & 296 & 7,7 & 7,6 & 3,1 & $\begin{array}{c}2,3 \\
4\end{array}$ & 414 & $\mathrm{HCO}_{3} \mathrm{Ca}-\mathrm{Mg}$ \\
\hline 24 & $44^{\circ} 27^{\prime} 60$ & $33^{\circ} 51^{\prime} 10$ & +54 & 2018 & $\begin{array}{l}7 \\
4\end{array}$ & - & - & 90,9 & 4,5 & 3,8 & 0,47 & 293 & 9,7 & 4,7 & 1,7 & $\begin{array}{c}2,0 \\
2 \\
\end{array}$ & 407 & $\mathrm{HCO}_{3} \mathrm{Ca}$ \\
\hline 24 & $44^{\circ} 27^{\prime} 60$ & $33^{\circ} 51^{\prime} 10$ & +54 & 2019 & $\begin{array}{l}7 \\
4\end{array}$ & $\begin{array}{c}180, \\
5\end{array}$ & 8,33 & 88,0 & 7,3 & 5,1 & 0,35 & 299 & 8,6 & 5,8 & 2,3 & $\begin{array}{c}2,7 \\
4\end{array}$ & 417 & $\mathrm{HCO}_{3}$ Ca-Mg \\
\hline 25 & $44^{\circ} 27^{\prime \prime} 55$ & $33^{\circ} 51_{\prime \prime}^{\prime} 30$ & +412 & 2019 & $\begin{array}{l}7 \\
5\end{array}$ & $\begin{array}{c}155 \\
3\end{array}$ & 7,16 & 90,0 & 5,4 & 3,1 & 0,26 & 292 & 6,4 & 5,8 & 2,1 & $\begin{array}{c}1,9 \\
9\end{array}$ & 403 & $\mathrm{HCO}_{3} \mathrm{Ca}$ \\
\hline 25 & $44^{\circ} 27^{\prime} 55$ & $33^{\circ} 51^{\prime} 30$ & +412 & 2018 & $\begin{array}{l}7, \\
5\end{array}$ & - & - & 116,0 & 4,3 & 5,9 & 0,49 & 368 & 8,0 & 3,2 & 2,4 & $\begin{array}{c}1,9 \\
9\end{array}$ & 503 & $\mathrm{HCO}_{3} \mathrm{Ca}$ \\
\hline \multicolumn{5}{|c|}{ Среднее значение: } & $\begin{array}{l}7, \\
7 \\
\end{array}$ & $\begin{array}{c}151, \\
5 \\
\end{array}$ & 7,9 & 90,2 & 5,7 & 4,5 & 0,45 & 321 & 8,2 & 5,1 & 2,5 & $\begin{array}{c}2,2 \\
3\end{array}$ & 444 & - \\
\hline \multicolumn{19}{|c|}{ Поверхностные воды, подверженные влиянию процессов континентального засоления (VIII группа) } \\
\hline 26 & $44^{\circ} 26^{\prime} 30$ & $33^{\circ} 46^{\prime} 10$ & +267 & 2019 & $\begin{array}{c}8, \\
0\end{array}$ & $\begin{array}{c}160 \\
0\end{array}$ & 9,49 & 66,0 & 12,0 & 3,6 & 2,40 & 182 & 22,0 & 36,0 & 2,1 & $\begin{array}{c}4,1 \\
3 \\
\end{array}$ & 326 & $\mathrm{HCO}_{3}-\mathrm{Cl}-\mathrm{SO}_{4} \mathrm{Ca}-\mathrm{Mg}$ \\
\hline 27 & $44^{\circ} 27^{\prime} 50$ & $33^{\circ} 42^{\prime} 20$ & +261 & 2019 & $\begin{array}{l}8, \\
9\end{array}$ & $\begin{array}{c}177, \\
0\end{array}$ & 12,25 & 33,5 & 6,1 & 20,0 & 1,80 & 120 & 13,7 & 29,4 & 0,9 & $\begin{array}{c}0,3 \\
1\end{array}$ & 225 & $\mathrm{HCO}_{3}-\mathrm{Cl} \mathrm{Ca}-\mathrm{Na}-\mathrm{Mg}$ \\
\hline 28 & $44^{\circ} 28^{\prime} 35$ & $33^{\circ} 52^{\prime} 50$ & +358 & 2019 & $\begin{array}{c}8, \\
3\end{array}$ & $\begin{array}{c}159, \\
5\end{array}$ & 8,89 & 65,0 & 9,2 & 14,2 & 2,10 & 250 & 10,7 & 13,0 & 0,0 & $\begin{array}{c}1,0 \\
3\end{array}$ & 364 & $\mathrm{HCO}_{3} \mathrm{Ca}-\mathrm{Mg}-\mathrm{Na}$ \\
\hline 29 & $44^{\circ} 29^{\prime} 40$ & $33^{\circ} 48^{\prime} 30$ & +252 & 2018 & $\begin{array}{l}8, \\
3\end{array}$ & - & - & 42,9 & 4,5 & 3,5 & 0,84 & 135 & 15,0 & 5,7 & 7,4 & $\begin{array}{c}0,2 \\
4\end{array}$ & 207 & $\mathrm{HCO}_{3}-\mathrm{SO}_{4} \mathrm{Ca}-\mathrm{Mg}$ \\
\hline 29 & $44^{\circ} 29^{\prime} 40$ & $33^{\circ} 48^{\prime} 30$ & +252 & 2019 & $\begin{array}{l}8, \\
3\end{array}$ & 116,4 & 8,63 & 44,0 & 4,3 & 4,4 & 0,54 & 151 & 6,6 & 5,9 & 0,0 & $\begin{array}{c}0,5 \\
0\end{array}$ & 217 & $\mathrm{HCO}_{3} \mathrm{Ca}-\mathrm{Mg}$ \\
\hline 30 & $44^{\circ} 29^{\prime} 30$ & $33^{\circ} 47^{\prime} 40$ & +222 & 2018 & $\begin{array}{c}8, \\
0\end{array}$ & - & - & 58,3 & 3,2 & 4,0 & 0,82 & 185 & 9,3 & 5,1 & 1,4 & $\begin{array}{c}0,9 \\
7\end{array}$ & 266 & $\mathrm{HCO}_{3} \mathrm{Ca}$ \\
\hline 30 & $44^{\circ} 29^{\prime \prime} 30$ & $33^{\circ} 47^{\prime} 40$ & +222 & 2019 & $\begin{array}{l}8, \\
2\end{array}$ & $\begin{array}{c}159 \\
2\end{array}$ & 8,86 & 51,0 & 7,9 & 4,5 & 0,54 & 186 & 8,6 & 6,2 & 0,5 & $\begin{array}{c}1,0 \\
8\end{array}$ & 265 & $\mathrm{HCO}_{3}$ Ca-Mg \\
\hline \multicolumn{5}{|c|}{ Среднее значение: } & $\begin{array}{l}8, \\
3\end{array}$ & $\begin{array}{c}154 \\
4\end{array}$ & 9,62 & 51,5 & 6,7 & 7,8 & 1,29 & 173 & 12,3 & 14,5 & 1,8 & $\begin{array}{c}1,1 \\
8\end{array}$ & 267 & - \\
\hline \multicolumn{5}{|c|}{ Гидрогеохимический фон: } & $\begin{array}{l}7 \\
4\end{array}$ & $\begin{array}{c}159, \\
2\end{array}$ & 8,33 & 98,0 & 8,5 & 14,2 & 0,82 & 317 & 16,0 & 19,0 & 2,2 & $\begin{array}{c}3,5 \\
4\end{array}$ & 497 & - \\
\hline
\end{tabular}

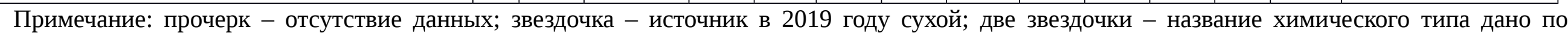
классификации С.А. Щукарева (в формулу добавлены макрокомпоненты с содержанием > 10 \%-экв). 
Таблица 2

Микроэлементный состав природных вод Байдарской долины

\begin{tabular}{|c|c|c|c|c|c|c|c|c|c|c|c|c|c|c|c|c|c|c|c|c|c|c|c|}
\hline \multirow{2}{*}{$\begin{array}{l}\text { № на } \\
\text { рис. } 1\end{array}$} & \multirow{2}{*}{ Год } & \multicolumn{22}{|c|}{ Элементы, мкг/дм ${ }^{3}$} \\
\hline & & $\mathrm{Li}$ & $\mathrm{Be}$ & B & $\mathrm{Al}$ & $\mathrm{P}$ & Sc & $\mathrm{Ti}$ & $\mathrm{V}$ & $\mathrm{Cr}$ & $\mathrm{Mn}$ & $\mathrm{Fe}$ & Co & $\mathrm{Ni}$ & $\mathrm{Cu}$ & $\mathrm{Zn}$ & Ga & $\mathrm{Ge}$ & As & $\mathrm{Se}$ & $\mathrm{Br}$ & $\mathrm{Rb}$ & $\mathrm{Sr}$ \\
\hline 1 & 2 & 3 & 4 & 5 & 6 & 7 & 8 & 9 & 10 & 11 & 12 & 13 & 14 & 15 & 16 & 17 & 18 & 19 & 20 & 21 & 22 & 23 & 24 \\
\hline \multicolumn{24}{|c|}{ I груnпа } \\
\hline 1 & 2018 & 1,7 & - & 45,6 & 10,2 & 404,0 & 0,19 & 1,44 & 0,36 & 0,78 & 140,3 & 150,0 & 0,40 & 1,01 & 1,11 & 9,6 & 0,0112 & 0,0124 & 1,76 & 0,65 & 23,7 & 3,58 & 148,6 \\
\hline 1 & 2019 & 2,0 & - & 47,9 & 4,0 & 291,2 & 0,43 & 0,81 & 0,30 & 1,67 & 28,8 & 169,7 & 0,17 & 0,95 & 0,49 & 2,4 & 0,0017 & 0,0076 & 0,91 & 0,41 & 29,9 & 2,78 & 171,3 \\
\hline 2 & 2018 & 1,7 & 0,016 & 2,2 & 9,2 & 11,0 & 0,52 & 2,79 & 0,34 & 0,44 & 10,9 & 140,0 & 0,17 & 0,40 & 1,30 & 13,5 & 0,0032 & 0,0167 & 0,25 & 0,09 & 40,6 & 0,16 & 255,7 \\
\hline 2 & 2019 & 2,9 & - & 25,3 & 1,9 & 0,5 & 0,22 & 0,34 & 0,41 & 1,45 & 2,3 & 74,5 & 0,05 & 0,12 & 0,19 & 3,4 & 0,0100 & 0,0029 & 0,26 & 0,11 & 36,2 & 0,20 & 188,0 \\
\hline 3 & 2018 & 0,4 & 0,011 & 37,7 & 32,3 & 52,0 & 0,25 & 2,29 & 0,58 & 1,55 & 123,0 & 260,0 & 1,33 & 2,45 & 4,80 & 23,2 & 0,0230 & 0,0190 & 0,62 & - & 76,0 & 0,73 & 976,0 \\
\hline 3 & 2019 & 7,2 & - & 46,5 & 1,5 & 6,5 & 0,16 & 0,42 & 0,37 & 3,60 & 14,2 & 330,2 & 0,07 & 0,60 & 0,22 & 0,3 & 0,0017 & 0,0170 & 0,60 & 0,65 & 104,4 & 0,63 & $\begin{array}{c}1217 \\
6 \\
\end{array}$ \\
\hline 4 & 2018 & 7,6 & 0,020 & 40,9 & 2,9 & 12,5 & 9,9 & 2,70 & 0,50 & 0,19 & 0,6 & 320,0 & 0,05 & 0,41 & 2,00 & 6,6 & 0,0030 & 0,0016 & 0,08 & - & 61,0 & 0,87 & $\begin{array}{c}1657 \\
0 \\
\end{array}$ \\
\hline 4 & 2019 & 8,0 & - & 47,5 & 0,4 & 6,5 & 0,38 & 0,47 & 0,30 & 2,58 & 0,1 & 113,0 & 0,04 & 0,15 & 0,36 & - & 0,0089 & - & 0,11 & 0,11 & 47,0 & 0,97 & $\begin{array}{c}1523 \\
0\end{array}$ \\
\hline 5 & 2018* & 2,3 & 0,026 & 17,9 & 4,1 & 24,9 & 0,25 & 1,07 & 0,58 & 0,85 & 10,5 & 230,0 & 0,13 & 0,50 & 1,24 & 12,0 & 0,0030 & 0,0039 & 0,23 & - & 77,0 & 0,18 & 255,0 \\
\hline \multicolumn{2}{|c|}{ Среднее: } & 3,8 & 0,018 & 34,6 & 7,4 & 89,9 & 1,37 & 1,37 & 0,42 & 1,46 & 36,7 & 198,6 & 0,27 & 0,73 & 1,30 & 8,9 & $\mathbf{0 , 0 0 7 3}$ & 0,0101 & 0,54 & 0,34 & 55,1 & 1,12 & 710,2 \\
\hline \multicolumn{24}{|c|}{ II груnna } \\
\hline 6 & 2018 & 3,8 & - & 41,2 & 1,3 & 10,0 & 77,0 & 0,69 & 0,36 & 0,64 & 0,6 & 163,4 & 0,04 & 0,19 & 0,51 & 3,0 & 0,0032 & 0,0021 & 0,10 & 0,30 & 79,6 & 0,17 & 467,1 \\
\hline 6 & 2019 & 4,1 & - & 44,1 & 1,8 & 10,2 & 54,0 & 0,44 & 0,58 & 1,66 & 0,2 & 77,0 & 0,03 & 0,10 & 0,19 & - & - & - & 0,13 & - & 68,0 & 0,20 & 555,3 \\
\hline 7 & 2018 & 5,1 & 0,033 & 35,0 & 21,0 & 54,0 & 0,19 & 1,31 & 0,36 & 7,00 & 2,8 & 200,0 & 0,09 & 0,89 & 6,50 & 45,6 & 0,0153 & 0,0142 & 0,28 & 0,65 & 38,0 & 0,35 & 246,0 \\
\hline 7 & 2019 & 7,6 & - & 43,4 & 8,6 & 9,9 & 0,43 & 0,24 & 0,30 & 1,37 & 0,3 & 78,8 & 0,03 & 0,23 & 0,38 & 0,5 & 0,0038 & - & 0,19 & 0,41 & 41,6 & 0,30 & 258,4 \\
\hline \multicolumn{2}{|c|}{ Среднее: } & 5,2 & 0,033 & 40,9 & 8,2 & 21,0 & 32,91 & 0,67 & 0,40 & 2,67 & 1,0 & 129,8 & 0,05 & 0,35 & 1,90 & 16,4 & $\mathbf{0 , 0 0 7 4}$ & 0,0082 & $\mathbf{0 , 1 8}$ & 0,45 & 56,8 & 0,26 & 381,7 \\
\hline \multicolumn{24}{|c|}{ III групnа } \\
\hline 8 & 2018 & 16,1 & - & 67,2 & 0,9 & 18,3 & 0,52 & 0,51 & 0,34 & 2,24 & 0,2 & 131,1 & 0,08 & 0,47 & 0,41 & 0,0 & - & - & 0,19 & 0,09 & 92,6 & 0,43 & 900,4 \\
\hline 8 & 2019 & 9,4 & - & 62,5 & 7,7 & 35,0 & 0,22 & 1,50 & 0,41 & 0,70 & 30,6 & 180,0 & 0,29 & 1,37 & 2,90 & 15,1 & 0,0065 & 0,0066 & 0,65 & 0,11 & 127,0 & 0,55 & 622,0 \\
\hline 9 & 2018* & 13,0 & - & 67,0 & 6,1 & 31,0 & 260,0 & 1,13 & 0,37 & 0,90 & 1,2 & 150,0 & 0,10 & 0,41 & 0,98 & 12,3 & 0,0026 & 0,0065 & 0,31 & 0,65 & 81,0 & 0,44 & 840,0 \\
\hline 10 & 2019 & 7,5 & - & 72,1 & 2,3 & 28,1 & 0,30 & 0,36 & 0,30 & 1,42 & 0,2 & 72,1 & 0,03 & 0,07 & 0,17 & - & - & - & 0,55 & 0,11 & 75,5 & 0,53 & 351,0 \\
\hline \multicolumn{2}{|c|}{ Среднее: } & 11,5 & & 67,2 & 4,3 & 28,1 & 65,26 & 0,88 & 0,36 & 1,32 & 8,1 & 133,3 & 0,13 & 0,58 & 1,12 & 9,1 & 0,0046 & 0,0066 & 0,43 & 0,24 & 94,0 & 0,49 & 678,4 \\
\hline \multicolumn{24}{|c|}{ IV груnna } \\
\hline 11 & $2018 *$ & 13,6 & - & 78,3 & 12,2 & 260,0 & 0,30 & 0,96 & 0,30 & 1,15 & 0,9 & 140,0 & 0,06 & 0,57 & 2,56 & 10,7 & - & 0,0052 & 1,12 & 0,11 & 104,0 & 0,35 & 310,0 \\
\hline 12 & 2019 & 37,1 & - & 277,2 & 6,9 & 80,3 & 0,19 & 0,46 & 0,17 & 1,49 & 5,5 & 106,8 & 0,31 & 2,47 & 10,27 & 267,1 & 0,0019 & - & 0,96 & - & 187,7 & 0,25 & 516,1 \\
\hline 13 & 2019 & 27,7 & - & 135,7 & 24,4 & 77,0 & 0,19 & 0,62 & 0,17 & 1,50 & 12,2 & 132,5 & 0,12 & 5,13 & 14,75 & 120,0 & 0,0328 & 0,0173 & 1,39 & - & 210,2 & 6,26 & $\begin{array}{c}1550 \\
0\end{array}$ \\
\hline 14 & 2018* & 6,8 & - & 6,6 & 5,6 & 14,2 & 80,3 & 0,70 & 0,41 & 0,51 & 1,1 & 150,0 & 0,13 & 0,82 & 1,95 & 9,8 & \begin{tabular}{|l|}
0,0196 \\
\end{tabular} & 0,0015 & 0,34 & 0,11 & 132,1 & 0,62 & 500,2 \\
\hline
\end{tabular}




\begin{tabular}{|c|c|c|c|c|c|c|c|c|c|c|c|c|c|c|c|c|c|c|c|c|c|c|c|}
\hline & Треднее: & 21,3 & - & 124,5 & 12,3 & 107,9 & 20,25 & 0,69 & 0,26 & 1,16 & 4,9 & 132,3 & 0,16 & 2,25 & 7,38 & 101,9 & 0,0181 & 0,0080 & 0,95 & 0,11 & 158,5 & 1,87 & 719,1 \\
\hline \multicolumn{24}{|c|}{ V группа } \\
\hline 15 & 2018* & 7,5 & 0,031 & 62,8 & 4,0 & 14,5 & 0,52 & 0,97 & 0,34 & 0,80 & 84,1 & 300,0 & 0,25 & 1,11 & 1,88 & 7,2 & 0,0028 & 0,0050 & 0,49 & 0,09 & 172,0 & 0,31 & 812,0 \\
\hline 16 & $2018^{*}$ & 4,4 & - & 39,2 & 4,7 & 18,7 & 0,16 & 0,48 & 0,37 & 0,62 & 1,2 & 82,9 & 0,03 & 0,39 & 1,08 & 3,4 & 0,0046 & 0,0155 & 0,32 & 0,65 & 17,3 & 0,57 & 186,4 \\
\hline & реднее: & 6,0 & 0,031 & 51,0 & 4,4 & 16,6 & 0,34 & 0,73 & 0,36 & 0,71 & 42,7 & 191,5 & 0,14 & 0,75 & 1,48 & 5,3 & 0,0037 & 0,0103 & 0,41 & 0,37 & 94,7 & 0,44 & 499,2 \\
\hline \multicolumn{24}{|c|}{ VI группа } \\
\hline 17 & 2018 & 7,0 & 0,005 & 99,0 & 3,1 & 29,8 & 0,30 & 1,97 & 0,50 & 0,98 & 304,3 & 690,0 & 0,49 & 0,78 & 0,50 & 47,0 & 0,0278 & 0,0080 & 0,55 & - & 53,0 & 0,94 & 421,3 \\
\hline 17 & 2019 & 6,8 & 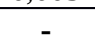 & 108,4 & 2,4 & 4,2 & 0,38 & 0,29 & 0,30 & 1,52 & 6,9 & 399,5 & 0,03 & 0,08 & 0,14 & 1,4 & 0,0018 & 0,0003 & 0,23 & 0,11 & 46,8 & 1,05 & 328,5 \\
\hline 18 & $2018^{*}$ & 4,8 & 0,013 & 115,9 & 9,9 & 31,5 & 0,29 & 2,36 & 0,36 & 1,33 & 2,0 & 350,0 & 0,39 & 0,76 & 1,40 & 35,1 & 0,0128 & 0,0049 & 0,43 & 0,30 & 39,9 & 0,53 & 375,0 \\
\hline & Бреднее: & 6,2 & 0,009 & 107,8 & 5,1 & 21,8 & 0,32 & 1,54 & 0,39 & 1,28 & 104,4 & 479,8 & 0,30 & 0,54 & 0,68 & 27,8 & 0,0141 & 0,0044 & 0,40 & 0,21 & 46,6 & 0,84 & 374,9 \\
\hline \multicolumn{24}{|c|}{ VII груnпа } \\
\hline 19 & 2018 & 1,3 & - & 10,0 & 0,6 & 4,0 & 0,30 & 0,66 & 0,30 & 1,30 & - & 210,0 & 0,08 & 0,29 & 1,00 & 2,3 & 0,0019 & 0,0041 & 0,18 & 0,11 & 22,4 & 0,23 & 170,0 \\
\hline 20 & 2018 & 1,9 & - & 10,0 & 0,2 & 7,0 & 0,38 & 0,78 & 0,30 & 1,20 & 0,6 & 420,0 & 0,08 & 0,30 & 0,89 & 0,6 & 0,0003 & 0,0091 & 0,20 & 0,11 & 18,6 & 0,26 & 180,0 \\
\hline 21 & 2018 & 1,8 & - & 10,0 & 0,4 & 2,0 & 0,30 & 0,49 & 0,50 & 0,70 & - & 120,0 & 0,04 & 0,17 & 0,67 & - & 0,0014 & 0,0071 & 0,19 & - & 19,2 & 0,30 & 170,0 \\
\hline 22 & 2018 & 0,7 & - & 2,4 & 4,6 & 11,6 & 0,19 & 0,83 & 0,36 & 0,20 & 1,0 & 200,0 & 0,05 & 0,30 & 2,71 & 50,3 & 0,0027 & 0,0079 & 0,14 & 0,65 & 11,6 & 0,23 & 142,8 \\
\hline 23 & 2018 & 2,3 & 0,016 & 12,6 & 7,2 & 7,2 & 0,25 & 1,21 & 0,58 & 0,27 & 1,1 & 160,0 & 0,05 & 0,35 & 16,50 & 43,0 & 0,0028 & 0,0060 & 0,36 & - & 21,0 & 0,37 & 275,0 \\
\hline 23 & 2019 & 1,8 & - & 9,6 & 1,2 & 8,1 & 0,16 & 0,36 & 0,37 & 0,89 & 0,0 & 50,5 & 0,02 & 0,10 & 0,73 & 0,1 & - & - & 0,34 & 0,65 & 15,6 & 0,25 & 202,1 \\
\hline 24 & 2018 & 1,5 & 0,016 & 12,0 & 1,4 & 8,2 & 0,52 & 0,54 & 0,34 & 0,61 & 0,2 & 155,3 & 0,03 & 0,22 & 2,18 & 4,1 & 0,0040 & 0,0026 & 0,02 & 0,09 & 19,7 & 0,25 & 166,5 \\
\hline 24 & 2019 & 1,7 & - & 12,1 & 3,1 & 9,7 & 0,22 & 0,34 & 0,41 & 1,37 & 0,2 & 65,6 & 0,04 & 0,09 & 0,38 & - & - & 0,0040 & 0,23 & 0,11 & 14,5 & 0,27 & 204,1 \\
\hline 25 & 2019 & 0,5 & - & 6,6 & 2,5 & 17,7 & 0,19 & 0,35 & 0,17 & 1,58 & 0,1 & 73,1 & 0,04 & 0,12 & 0,37 & 0,8 & - & - & 0,07 & - & 13,8 & 0,19 & 92,3 \\
\hline 25 & 2018 & 1,0 & 0,003 & 7,7 & 12,0 & 35,1 & 0,43 & 2,64 & 0,30 & 1,38 & 1,1 & 260,0 & 0,19 & 0,60 & 1,12 & 16,2 & 0,0173 & - & 0,09 & 0,41 & 13,6 & 0,23 & 367,0 \\
\hline \multicolumn{2}{|c|}{ Среднее: } & 1,5 & 0,012 & 9,3 & 3,3 & 11,1 & 0,29 & 0,82 & 0,36 & 0,95 & 0,5 & 171,5 & 0,06 & 0,25 & 2,66 & 14,7 & 0,0043 & 0,0058 & 0,18 & 0,30 & 17,0 & 0,26 & 197,0 \\
\hline \multicolumn{24}{|c|}{ VIII групnа } \\
\hline 26 & 2019 & 10,5 & - & 73,7 & 17,1 & 44,3 & 0,26 & 0,21 & 0,44 & 1,04 & 11,4 & 98,4 & 0,09 & 0,57 & 1,04 & - & 0,0065 & - & 1,81 & 0,29 & 108,9 & 0,49 & 403,6 \\
\hline 27 & 2019 & 6,4 & 0,022 & 53,2 & 7,1 & 14,8 & 0,05 & 0,18 & 0,16 & 0,58 & 0,8 & 33,4 & 0,03 & 0,43 & 0,35 & 0,1 & 0,0048 & - & 0,93 & 0,25 & 50,2 & - & 300,5 \\
\hline 28 & 2019 & 5,2 & - & 56,4 & 8,5 & 15,4 & 0,15 & 0,15 & 0,23 & 1,08 & 4,6 & 55,1 & 0,03 & 0,61 & 0,49 & 0,0 & 0,0019 & - & 0,93 & 0,08 & 47,3 & 0,10 & 255,5 \\
\hline 29 & 2018 & 1,2 & - & 14,0 & 11,5 & 10,1 & 0,03 & 0,31 & 0,39 & 0,40 & 6,6 & 80,0 & 0,03 & 0,55 & 1,74 & 11,0 & 0,0026 & 0,0007 & 0,49 & - & 25,4 & 0,32 & 132,0 \\
\hline 29 & 2019 & 1,2 & - & 12,8 & 7,3 & 22,3 & 0,06 & 0,10 & 0,33 & 0,76 & 0,6 & 40,4 & 0,02 & 0,36 & 0,57 & - & 0,0048 & - & 0,48 & 0,36 & 20,8 & 0,19 & 134,6 \\
\hline 30 & 2018 & 1,2 & - & 12,0 & 7,9 & 9,0 & 0,13 & 0,41 & 0,25 & 0,34 & 170,0 & 90,0 & 0,23 & 0,64 & 1,14 & 10,6 & 0,0190 & - & 0,55 & - & 32,3 & 0,29 & 142,8 \\
\hline 30 & 2019 & 1,3 & - & 15,0 & 6,3 & 19,3 & 0,10 & 0,23 & 0,22 & 0,83 & 4,7 & 42,7 & 0,02 & 0,23 & 0,55 & - & 0,0038 & - & 0,44 & 0,84 & 19,9 & 0,20 & 142,0 \\
\hline \multicolumn{2}{|c|}{ Среднее: } & 3,6 & 0,022 & 33,9 & 9,4 & 19,3 & 0,11 & 0,23 & 0,29 & 0,72 & 28,4 & 62,9 & 0,06 & 0,48 & $\mathbf{0 , 8 4}$ & 5,4 & 0,0062 & 0,0007 & 0,80 & 0,36 & 43,5 & 0,27 & 215,9 \\
\hline & Фон: & 4,1 & 0,016 & 40,9 & 4,7 & 14,8 & 0,35 & 0,54 & 0,29 & 1,00 & 1,2 & 140,0 & 0,06 & 0,41 & 1,00 & 9,6 & 0,0038 & 0,0060 & 0,34 & 0,38 & 41,6 & 0,31 & 275,0 \\
\hline
\end{tabular}

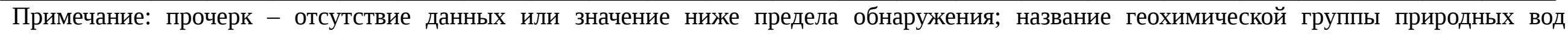
приведено в таблице 1.

Окончание табл. 2

\begin{tabular}{|c|c|c|c|c|c|c|c|c|c|c|c|c|c|c|c|c|c|c|c|c|c|c|}
\hline \multirow{2}{*}{$\begin{array}{l}\text { № на } \\
\text { рис. } 1 \\
\end{array}$} & \multirow{2}{*}{ Год } & \multicolumn{21}{|c|}{ Элементы, мкг/дм ${ }^{3}$} \\
\hline & & $\mathrm{Y}$ & $\mathrm{Zr}$ & $\mathrm{Nb}$ & Mo & $\mathrm{Ag}$ & $\mathrm{Cd}$ & In & Sn & $\mathrm{Sb}$ & $\mathrm{Te}$ & $\mathrm{I}$ & Cs & $\mathrm{Ba}$ & $\mathrm{La}$ & $\mathrm{Hf}$ & $\mathrm{Ta}$ & $\mathrm{W}$ & $\mathrm{Hg}$ & $\mathrm{Tl}$ & $\mathrm{Pb}$ & $\mathrm{Bi}$ \\
\hline 1 & 2 & 25 & 26 & 27 & 28 & 29 & 30 & 31 & 32 & 33 & 34 & 35 & 36 & 37 & 38 & 39 & 40 & 41 & 42 & 43 & 44 & 45 \\
\hline
\end{tabular}




\begin{tabular}{|c|c|c|c|c|c|c|c|c|c|c|c|c|c|c|c|c|c|c|c|c|c|c|}
\hline \multicolumn{23}{|c|}{ I групnа } \\
\hline 1 & 2018 & 0,07 & $\begin{array}{c}0,05 \\
3\end{array}$ & $\begin{array}{c}0,00 \\
3\end{array}$ & $\begin{array}{c}0,6 \\
1\end{array}$ & $\begin{array}{c}0,01 \\
8\end{array}$ & $\begin{array}{c}0,01 \\
3\end{array}$ & - & $\begin{array}{c}0,04 \\
5\end{array}$ & $\begin{array}{c}0,1 \\
7\end{array}$ & $\begin{array}{c}0,00 \\
8\end{array}$ & 8,1 & $\begin{array}{c}0,003 \\
1\end{array}$ & 17 & $\begin{array}{c}0,01 \\
4\end{array}$ & $\begin{array}{c}0,001 \\
7\end{array}$ & $\begin{array}{c}0,002 \\
8\end{array}$ & $\begin{array}{c}0,01 \\
0\end{array}$ & $\begin{array}{c}0,01 \\
0\end{array}$ & - & 0,349 & $\begin{array}{c}0,002 \\
6\end{array}$ \\
\hline 1 & 2019 & 0,02 & $\begin{array}{c}0,08 \\
0 \\
\end{array}$ & $\begin{array}{c}0,01 \\
0\end{array}$ & $\begin{array}{c}0,6 \\
3\end{array}$ & $\begin{array}{c}0,00 \\
1\end{array}$ & $\begin{array}{c}0,00 \\
2\end{array}$ & - & 0,011 & $\begin{array}{c}0,2 \\
3\end{array}$ & - & 8,8 & $\begin{array}{c}0,003 \\
1\end{array}$ & 27 & $\begin{array}{c}0,00 \\
9\end{array}$ & $\begin{array}{c}0,003 \\
6\end{array}$ & $\begin{array}{c}0,001 \\
9\end{array}$ & $\begin{array}{c}0,00 \\
3\end{array}$ & $\begin{array}{c}0,06 \\
0\end{array}$ & - & 0,306 & $\begin{array}{c}0,001 \\
6\end{array}$ \\
\hline 2 & 2018 & 0,12 & $\begin{array}{c}0,03 \\
5 \\
\end{array}$ & $\begin{array}{c}0,00 \\
2 \\
\end{array}$ & $\begin{array}{c}0,3 \\
3\end{array}$ & $\begin{array}{c}0,04 \\
5 \\
\end{array}$ & $\begin{array}{c}0,03 \\
5 \\
\end{array}$ & $\begin{array}{c}0,001 \\
0 \\
\end{array}$ & $\begin{array}{c}0,05 \\
1 \\
\end{array}$ & $\begin{array}{c}0,0 \\
6 \\
\end{array}$ & $\begin{array}{c}0,02 \\
1 \\
\end{array}$ & 4,7 & $\begin{array}{c}0,005 \\
3 \\
\end{array}$ & 60 & $\begin{array}{c}0,04 \\
2 \\
\end{array}$ & $\begin{array}{c}0,001 \\
3 \\
\end{array}$ & - & $\begin{array}{c}0,01 \\
3 \\
\end{array}$ & - & $\begin{array}{c}0,001 \\
0\end{array}$ & 0,127 & - \\
\hline 2 & 2019 & 0,00 & $\begin{array}{c}0,00 \\
7 \\
\end{array}$ & - & $\begin{array}{c}0,0 \\
3 \\
\end{array}$ & - & - & - & $\begin{array}{c}0,00 \\
6 \\
\end{array}$ & $\begin{array}{c}0,1 \\
3 \\
\end{array}$ & - & 9,9 & - & 38 & & - & - & - & $\begin{array}{c}0,02 \\
3\end{array}$ & - & 0,003 & - \\
\hline 3 & 2018 & 0,26 & $\begin{array}{c}0,22 \\
8 \\
\end{array}$ & $\begin{array}{c}0,00 \\
2 \\
\end{array}$ & $\begin{array}{c}0,5 \\
8 \\
\end{array}$ & $\begin{array}{c}0,03 \\
1 \\
\end{array}$ & $\begin{array}{c}0,02 \\
0 \\
\end{array}$ & - & $\begin{array}{c}0,03 \\
8 \\
\end{array}$ & $\begin{array}{c}0,2 \\
3 \\
\end{array}$ & $\begin{array}{c}0,02 \\
6 \\
\end{array}$ & 3,1 & $\begin{array}{c}0,015 \\
0 \\
\end{array}$ & 32 & $\begin{array}{c}0,06 \\
3 \\
\end{array}$ & $\begin{array}{c}0,005 \\
4 \\
\end{array}$ & $\begin{array}{c}0,000 \\
7 \\
\end{array}$ & $\begin{array}{c}0,02 \\
0 \\
\end{array}$ & - & - & 0,410 & $\begin{array}{c}0,002 \\
6 \\
\end{array}$ \\
\hline 3 & 2019 & 0,02 & $\begin{array}{c}0,03 \\
0\end{array}$ & - & $\begin{array}{c}0,0 \\
2\end{array}$ & - & $\begin{array}{c}0,00 \\
1\end{array}$ & - & $\begin{array}{c}0,00 \\
6\end{array}$ & $\begin{array}{c}0,1 \\
8\end{array}$ & & 44,8 & - & 21 & $\begin{array}{c}0,00 \\
4\end{array}$ & $\begin{array}{c}0,000 \\
7\end{array}$ & - & - & $\begin{array}{c}0,02 \\
3\end{array}$ & - & 0,005 & - \\
\hline 4 & 2018 & 0,05 & $\begin{array}{c}0,03 \\
4\end{array}$ & - & $\begin{array}{c}0,5 \\
0\end{array}$ & $\begin{array}{c}0,00 \\
4\end{array}$ & $\begin{array}{c}0,00 \\
6\end{array}$ & - & $\begin{array}{c}0,08 \\
7\end{array}$ & $\begin{array}{c}0,0 \\
3\end{array}$ & & 42,0 & $\begin{array}{c}0,003 \\
5\end{array}$ & 26 & $\begin{array}{c}0,01 \\
5\end{array}$ & $\begin{array}{c}0,001 \\
4\end{array}$ & $\begin{array}{c}0,000 \\
3\end{array}$ & $\begin{array}{c}0,00 \\
4\end{array}$ & - & $\begin{array}{c}0,004 \\
0\end{array}$ & 0,007 & $\begin{array}{c}0,000 \\
7\end{array}$ \\
\hline 4 & 2019 & 0,01 & $\begin{array}{c}0,00 \\
6 \\
\end{array}$ & - & $\begin{array}{c}0,7 \\
0\end{array}$ & - & - & - & $\begin{array}{c}0,00 \\
6 \\
\end{array}$ & $\begin{array}{c}0,0 \\
7 \\
\end{array}$ & - & 18,0 & $\begin{array}{c}0,004 \\
2 \\
\end{array}$ & 28 & - & - & - & - & $\begin{array}{c}0,02 \\
9 \\
\end{array}$ & $\begin{array}{c}0,002 \\
3 \\
\end{array}$ & 0,069 & - \\
\hline 5 & $2018^{*}$ & 0,11 & $\begin{array}{c}0,03 \\
0 \\
\end{array}$ & $\begin{array}{c}0,00 \\
3 \\
\end{array}$ & $\begin{array}{c}0,5 \\
8\end{array}$ & - & 0,011 & - & $\begin{array}{c}0,01 \\
5 \\
\end{array}$ & $\begin{array}{c}0,1 \\
0\end{array}$ & - & 6,5 & $\begin{array}{c}0,001 \\
0\end{array}$ & 29 & $\begin{array}{c}0,02 \\
9\end{array}$ & - & - & - & - & - & 0,410 & $\begin{array}{c}0,001 \\
9\end{array}$ \\
\hline \multicolumn{2}{|c|}{ Среднее: } & $\mathbf{0 , 0 7}$ & $\begin{array}{c}0,05 \\
6 \\
\end{array}$ & $\begin{array}{c}0,00 \\
4\end{array}$ & $\begin{array}{c}0,4 \\
4\end{array}$ & $\begin{array}{c}0,02 \\
0\end{array}$ & $\begin{array}{c}0,01 \\
3\end{array}$ & $\begin{array}{c}0,001 \\
0\end{array}$ & $\begin{array}{c}0,02 \\
9 \\
\end{array}$ & $\begin{array}{c}0,1 \\
3\end{array}$ & $\begin{array}{c}0,01 \\
8 \\
\end{array}$ & 16,2 & $\begin{array}{c}0,005 \\
0\end{array}$ & 31 & $\begin{array}{c}0,02 \\
5 \\
\end{array}$ & $\begin{array}{c}0,002 \\
4\end{array}$ & $\begin{array}{c}0,001 \\
4\end{array}$ & $\begin{array}{c}0,01 \\
0\end{array}$ & $\begin{array}{c}0,02 \\
9 \\
\end{array}$ & $\begin{array}{c}0,002 \\
4\end{array}$ & $\mathbf{0 , 1 8 7}$ & $\begin{array}{c}0,001 \\
9 \\
\end{array}$ \\
\hline \multicolumn{23}{|c|}{ II груnпа } \\
\hline 6 & 2018 & 0,02 & $\begin{array}{c}0,02 \\
0\end{array}$ & $\begin{array}{c}0,00 \\
6\end{array}$ & $\begin{array}{c}0,3 \\
9\end{array}$ & $\begin{array}{c}0,00 \\
2\end{array}$ & $\begin{array}{c}0,00 \\
8\end{array}$ & - & $\begin{array}{c}0,02 \\
7\end{array}$ & $\begin{array}{c}0,0 \\
3\end{array}$ & $\begin{array}{c}0,03 \\
2\end{array}$ & 32,0 & $\begin{array}{c}0,001 \\
8\end{array}$ & 16 & $\begin{array}{c}0,01 \\
0\end{array}$ & $\begin{array}{c}0,006 \\
5\end{array}$ & $\begin{array}{c}0,000 \\
7\end{array}$ & $\begin{array}{c}0,00 \\
0\end{array}$ & $\begin{array}{c}0,02 \\
9\end{array}$ & - & 0,131 & $\begin{array}{c}0,002 \\
5\end{array}$ \\
\hline 6 & 2019 & 0,00 & - & - & $\begin{array}{c}0,5 \\
8\end{array}$ & - & - & - & - & $\begin{array}{c}0,2 \\
1\end{array}$ & - & 21,5 & - & 20 & - & - & - & $\begin{array}{c}0,00 \\
2\end{array}$ & $\begin{array}{c}0,01 \\
2\end{array}$ & - & 0,410 & - \\
\hline 7 & 2018 & 0,05 & $\begin{array}{c}0,03 \\
6\end{array}$ & $\begin{array}{c}0,00 \\
0\end{array}$ & $\begin{array}{c}0,6 \\
1\end{array}$ & $\begin{array}{c}0,03 \\
9\end{array}$ & $\begin{array}{c}0,00 \\
9\end{array}$ & $\begin{array}{c}0,000 \\
5\end{array}$ & $\begin{array}{c}0,04 \\
3\end{array}$ & $\begin{array}{c}0,1 \\
4\end{array}$ & $\begin{array}{c}0,00 \\
2\end{array}$ & 10,3 & $\begin{array}{c}0,006 \\
1\end{array}$ & 68 & $\begin{array}{c}0,02 \\
9\end{array}$ & $\begin{array}{c}0,002 \\
2\end{array}$ & $\begin{array}{c}0,001 \\
0\end{array}$ & $\begin{array}{c}0,04 \\
3\end{array}$ & - & $\begin{array}{c}0,000 \\
5\end{array}$ & 0,349 & $\begin{array}{c}0,002 \\
5\end{array}$ \\
\hline 7 & 2019 & 0,00 & $\begin{array}{c}0,00 \\
9\end{array}$ & $\begin{array}{c}0,00 \\
1\end{array}$ & $\begin{array}{c}0,6 \\
3\end{array}$ & - & - & $\begin{array}{c}0,000 \\
2\end{array}$ & $\begin{array}{c}0,00 \\
1\end{array}$ & $\begin{array}{c}0,1 \\
8\end{array}$ & - & 5,6 & $\begin{array}{c}0,000 \\
5\end{array}$ & 64 & $\begin{array}{c}0,00 \\
4\end{array}$ & - & $\begin{array}{c}0,001 \\
5\end{array}$ & $\begin{array}{c}0,00 \\
4\end{array}$ & $\begin{array}{c}0,00 \\
6\end{array}$ & $\begin{array}{c}0,000 \\
2\end{array}$ & 0,306 & $\begin{array}{c}0,012 \\
0\end{array}$ \\
\hline & реднее: & 0,02 & $\begin{array}{c}0,02 \\
2 \\
\end{array}$ & $\begin{array}{c}0,00 \\
2 \\
\end{array}$ & $\begin{array}{c}0,5 \\
5 \\
\end{array}$ & $\begin{array}{c}0,02 \\
1 \\
\end{array}$ & $\begin{array}{c}0,00 \\
9 \\
\end{array}$ & $\begin{array}{c}0,000 \\
4 \\
\end{array}$ & $\begin{array}{c}0,02 \\
4 \\
\end{array}$ & $\begin{array}{c}0,1 \\
4 \\
\end{array}$ & $\begin{array}{c}\mathbf{0 , 0 1} \\
7 \\
\end{array}$ & 17,4 & $\begin{array}{c}0,002 \\
8 \\
\end{array}$ & 42 & $\begin{array}{c}0,01 \\
4 \\
\end{array}$ & $\begin{array}{c}0,004 \\
4\end{array}$ & 0,0011 & $\begin{array}{c}0,01 \\
2 \\
\end{array}$ & $\begin{array}{c}0,01 \\
6 \\
\end{array}$ & $\begin{array}{c}0,000 \\
4\end{array}$ & 0,299 & $\begin{array}{c}0,005 \\
7 \\
\end{array}$ \\
\hline \multicolumn{23}{|c|}{ III групnа } \\
\hline 8 & 2018 & 0,02 & $\begin{array}{c}0,00 \\
7 \\
\end{array}$ & $\begin{array}{c}0,00 \\
1 \\
\end{array}$ & $\begin{array}{c}0,3 \\
3 \\
\end{array}$ & - & - & - & - & $\begin{array}{c}0,6 \\
7 \\
\end{array}$ & - & 15,8 & - & 77 & - & - & - & - & $\begin{array}{c}0,03 \\
5 \\
\end{array}$ & & 0,127 & $\begin{array}{c}0,014 \\
1 \\
\end{array}$ \\
\hline 8 & 2019 & 0,05 & $\begin{array}{c}0,03 \\
4 \\
\end{array}$ & - & $\begin{array}{c}0,0 \\
3 \\
\end{array}$ & - & $\begin{array}{c}0,02 \\
9 \\
\end{array}$ & - & $\begin{array}{c}0,09 \\
6 \\
\end{array}$ & $\begin{array}{c}0,1 \\
8 \\
\end{array}$ & $\begin{array}{c}0,03 \\
6 \\
\end{array}$ & 46,6 & $\begin{array}{c}0,004 \\
0 \\
\end{array}$ & 39 & $\begin{array}{c}0,01 \\
2 \\
\end{array}$ & $\begin{array}{c}0,002 \\
1\end{array}$ & $\begin{array}{c}0,000 \\
4\end{array}$ & $\begin{array}{c}0,01 \\
6 \\
\end{array}$ & - & $\begin{array}{c}0,015 \\
8\end{array}$ & 0,003 & $\begin{array}{c}0,004 \\
5 \\
\end{array}$ \\
\hline 9 & $2018^{*}$ & 0,11 & $\begin{array}{c}0,01 \\
4 \\
\end{array}$ & $\begin{array}{c}0,00 \\
4 \\
\end{array}$ & $\begin{array}{c}0,0 \\
2 \\
\end{array}$ & $\begin{array}{c}0,00 \\
3 \\
\end{array}$ & - & - & $\begin{array}{c}0,03 \\
8 \\
\end{array}$ & $\begin{array}{c}0,0 \\
8 \\
\end{array}$ & - & 26,7 & $\begin{array}{c}0,002 \\
0\end{array}$ & 64 & $\begin{array}{c}0,04 \\
0 \\
\end{array}$ & $\begin{array}{c}0,001 \\
6 \\
\end{array}$ & $\begin{array}{c}0,001 \\
6\end{array}$ & $\begin{array}{c}0,01 \\
4\end{array}$ & - & $\begin{array}{c}0,003 \\
1\end{array}$ & 0,005 & $\begin{array}{c}0,001 \\
2\end{array}$ \\
\hline 10 & 2019 & - & - & - & $\begin{array}{c}0,5 \\
0\end{array}$ & - & - & - & - & $\begin{array}{c}0,1 \\
2\end{array}$ & - & 9,4 & - & 22 & - & - & - & - & $\begin{array}{c}0,00 \\
7\end{array}$ & - & 0,027 & - \\
\hline \multicolumn{2}{|c|}{ Среднее: } & 0,06 & $\begin{array}{c}0,01 \\
8\end{array}$ & $\begin{array}{c}0,00 \\
3\end{array}$ & $\begin{array}{c}0,2 \\
2\end{array}$ & $\begin{array}{c}0,00 \\
3\end{array}$ & $\begin{array}{c}0,02 \\
9\end{array}$ & & $\begin{array}{c}0,06 \\
7\end{array}$ & $\begin{array}{c}0,2 \\
6\end{array}$ & $\begin{array}{c}0,03 \\
6\end{array}$ & 24,6 & $\begin{array}{c}0,003 \\
0\end{array}$ & 51 & $\begin{array}{c}0,02 \\
6\end{array}$ & $\begin{array}{c}0,001 \\
9\end{array}$ & $\begin{array}{c}0,001 \\
0\end{array}$ & $\begin{array}{c}0,01 \\
5\end{array}$ & $\begin{array}{c}0,02 \\
1\end{array}$ & $\begin{array}{c}0,009 \\
5\end{array}$ & 0,041 & $\begin{array}{c}0,006 \\
6\end{array}$ \\
\hline
\end{tabular}




\begin{tabular}{|c|c|c|c|c|c|c|c|c|c|c|c|c|c|c|c|c|c|c|c|c|c|c|}
\hline \multicolumn{23}{|c|}{ IV групnа } \\
\hline 11 & $2018 *$ & 0,02 & $\begin{array}{c}0,02 \\
0\end{array}$ & - & $\begin{array}{c}0,5 \\
0\end{array}$ & $\begin{array}{c}0,00 \\
5\end{array}$ & $\begin{array}{c}0,00 \\
7\end{array}$ & - & $\begin{array}{c}0,01 \\
2\end{array}$ & $\begin{array}{c}0,1 \\
7\end{array}$ & $\begin{array}{c}0,01 \\
4\end{array}$ & 17,0 & $\begin{array}{c}0,001 \\
3\end{array}$ & 65 & $\begin{array}{c}0,01 \\
2\end{array}$ & $\begin{array}{c}0,003 \\
7\end{array}$ & - & - & - & - & 0,027 & - \\
\hline 12 & 2019 & 0,02 & $\begin{array}{c}0,06 \\
1 \\
\end{array}$ & $\begin{array}{c}0,00 \\
3 \\
\end{array}$ & $\begin{array}{c}0,0 \\
1 \\
\end{array}$ & $\begin{array}{c}0,00 \\
6\end{array}$ & $\begin{array}{c}0,04 \\
9\end{array}$ & - & 0,011 & $\begin{array}{c}0,3 \\
3\end{array}$ & - & 65,2 & $\begin{array}{c}0,001 \\
5\end{array}$ & 56 & $\begin{array}{c}0,00 \\
9\end{array}$ & $\begin{array}{c}0,000 \\
8\end{array}$ & $\begin{array}{c}0,002 \\
4\end{array}$ & $\begin{array}{c}0,00 \\
7\end{array}$ & $\begin{array}{c}0,03 \\
1\end{array}$ & - & 0,004 & $\begin{array}{c}0,005 \\
9\end{array}$ \\
\hline 13 & 2019 & 0,06 & $\begin{array}{c}0,02 \\
8\end{array}$ & $\begin{array}{c}0,01 \\
0\end{array}$ & $\begin{array}{c}0,0 \\
1\end{array}$ & $\begin{array}{c}0,00 \\
7\end{array}$ & $\begin{array}{c}0,01 \\
8\end{array}$ & - & $\begin{array}{c}0,27 \\
2\end{array}$ & $\begin{array}{c}0,3 \\
2\end{array}$ & - & 15,7 & $\begin{array}{c}0,012 \\
3\end{array}$ & $\begin{array}{c}10 \\
0\end{array}$ & $\begin{array}{c}0,04 \\
1\end{array}$ & $\begin{array}{c}0,000 \\
8\end{array}$ & $\begin{array}{c}0,003 \\
1\end{array}$ & $\begin{array}{c}0,01 \\
5\end{array}$ & $\begin{array}{c}0,03 \\
1\end{array}$ & - & 0,004 & $\begin{array}{c}0,008 \\
8\end{array}$ \\
\hline 14 & $2018 *$ & 0,02 & $\begin{array}{c}0,03 \\
6\end{array}$ & $\begin{array}{c}0,00 \\
9\end{array}$ & $\begin{array}{c}0,0 \\
3\end{array}$ & - & $\begin{array}{c}0,00 \\
9\end{array}$ & $\begin{array}{c}0,001 \\
7\end{array}$ & $\begin{array}{c}0,03 \\
1\end{array}$ & $\begin{array}{c}0,2 \\
2\end{array}$ & $\begin{array}{c}0,03 \\
8\end{array}$ & 90,0 & $\begin{array}{c}0,040 \\
5\end{array}$ & 17 & $\begin{array}{c}0,01 \\
0\end{array}$ & $\begin{array}{c}0,002 \\
1\end{array}$ & - & $\begin{array}{c}0,02 \\
1\end{array}$ & - & $\begin{array}{c}0,001 \\
7\end{array}$ & 0,003 & $\begin{array}{c}0,002 \\
5\end{array}$ \\
\hline \multicolumn{2}{|c|}{ Среднее: } & 0,03 & $\begin{array}{c}0,03 \\
6 \\
\end{array}$ & $\begin{array}{c}0,00 \\
7 \\
\end{array}$ & $\begin{array}{c}0,1 \\
4 \\
\end{array}$ & $\begin{array}{c}0,00 \\
6 \\
\end{array}$ & $\begin{array}{c}0,02 \\
1 \\
\end{array}$ & $\begin{array}{c}0,001 \\
7 \\
\end{array}$ & $\begin{array}{c}0,08 \\
2 \\
\end{array}$ & $\begin{array}{c}0,2 \\
6\end{array}$ & $\begin{array}{c}0,02 \\
6 \\
\end{array}$ & 47,0 & $\begin{array}{c}0,013 \\
9 \\
\end{array}$ & 60 & $\begin{array}{c}0,01 \\
8 \\
\end{array}$ & $\begin{array}{c}0,001 \\
9 \\
\end{array}$ & $\begin{array}{c}0,002 \\
8 \\
\end{array}$ & $\begin{array}{c}0,01 \\
4 \\
\end{array}$ & $\begin{array}{c}0,03 \\
1 \\
\end{array}$ & $\begin{array}{c}\mathbf{0 , 0 0 1} \\
7 \\
\end{array}$ & $\mathbf{0 , 0 1 0}$ & $\begin{array}{c}0,005 \\
7 \\
\end{array}$ \\
\hline \multicolumn{23}{|c|}{$V$ группа } \\
\hline 15 & $2018 *$ & 0,11 & $\begin{array}{c}0,04 \\
0\end{array}$ & - & $\begin{array}{c}0,3 \\
3\end{array}$ & $\begin{array}{c}0,00 \\
4\end{array}$ & $\begin{array}{c}0,05 \\
5\end{array}$ & - & $\begin{array}{c}0,01 \\
7\end{array}$ & $\begin{array}{c}0,1 \\
2\end{array}$ & $\begin{array}{c}0,00 \\
1\end{array}$ & $\begin{array}{c}138 \\
0\end{array}$ & - & 46 & $\begin{array}{c}0,03 \\
6\end{array}$ & $\begin{array}{c}0,000 \\
6\end{array}$ & - & & - & $\begin{array}{c}0,002 \\
3\end{array}$ & 0,127 & - \\
\hline 16 & 2018* & 0,02 & $\begin{array}{c}0,02 \\
8\end{array}$ & - & $\begin{array}{c}0,0 \\
2\end{array}$ & $\begin{array}{c}0,01 \\
5\end{array}$ & $\begin{array}{c}0,00 \\
5\end{array}$ & $\begin{array}{c}0,000 \\
2\end{array}$ & $\begin{array}{c}0,07 \\
9\end{array}$ & $\begin{array}{c}0,1 \\
6\end{array}$ & $\begin{array}{c}0,00 \\
4\end{array}$ & 4,7 & $\begin{array}{c}0,002 \\
6\end{array}$ & 19 & $\begin{array}{c}0,02 \\
2\end{array}$ & - & $\begin{array}{c}0,001 \\
6\end{array}$ & $\begin{array}{c}0,01 \\
0\end{array}$ & - & $\begin{array}{c}0,006 \\
1\end{array}$ & 0,005 & - \\
\hline & реднее: & $\mathbf{0 , 0 7}$ & $\begin{array}{c}0,03 \\
4\end{array}$ & & $\begin{array}{c}0,1 \\
8\end{array}$ & $\begin{array}{c}0,01 \\
0\end{array}$ & $\begin{array}{c}0,03 \\
0\end{array}$ & $\begin{array}{c}0,000 \\
2\end{array}$ & $\begin{array}{c}0,04 \\
8\end{array}$ & $\begin{array}{c}0,1 \\
4\end{array}$ & $\begin{array}{c}0,00 \\
3\end{array}$ & 71,4 & $\begin{array}{c}0,002 \\
6\end{array}$ & 33 & $\begin{array}{c}0,02 \\
9\end{array}$ & $\begin{array}{c}0,000 \\
6\end{array}$ & $\begin{array}{c}0,001 \\
6\end{array}$ & 0,01 & & $\begin{array}{c}0,004 \\
2\end{array}$ & 0,066 & - \\
\hline \multicolumn{23}{|c|}{ VI групnа } \\
\hline 17 & 2018 & 0,02 & $\begin{array}{c}0,03 \\
3\end{array}$ & - & $\begin{array}{c}0,5 \\
0\end{array}$ & $\begin{array}{c}0,01 \\
4\end{array}$ & $\begin{array}{c}0,00 \\
6\end{array}$ & - & $\begin{array}{c}0,16 \\
2\end{array}$ & $\begin{array}{c}0,0 \\
4\end{array}$ & - & 5,6 & $\begin{array}{c}0,015 \\
7\end{array}$ & 93 & $\begin{array}{c}0,01 \\
0\end{array}$ & $\begin{array}{c}0,000 \\
7\end{array}$ & - & $\begin{array}{c}0,00 \\
8\end{array}$ & - & - & 0,007 & $\begin{array}{c}0,001 \\
4\end{array}$ \\
\hline 17 & 2019 & 0,01 & $\begin{array}{c}0,00 \\
2\end{array}$ & - & $\begin{array}{c}0,7 \\
0\end{array}$ & - & - & - & $\begin{array}{c}0,00 \\
2\end{array}$ & $\begin{array}{c}0,1 \\
3\end{array}$ & - & 6,2 & $\begin{array}{c}0,016 \\
3\end{array}$ & 117 & $\begin{array}{c}0,00 \\
5\end{array}$ & & - & - & - & - & 0,069 & - \\
\hline 18 & $2018 *$ & 0,04 & $\begin{array}{c}0,43 \\
1\end{array}$ & - & $\begin{array}{c}0,3 \\
9\end{array}$ & $\begin{array}{c}0,01 \\
2\end{array}$ & $\begin{array}{c}0,00 \\
7\end{array}$ & - & $\begin{array}{c}0,13 \\
8\end{array}$ & $\begin{array}{c}0,0 \\
7\end{array}$ & $\begin{array}{c}0,00 \\
1\end{array}$ & 3,0 & 0,0110 & 49 & $\begin{array}{c}0,01 \\
6\end{array}$ & $\begin{array}{c}0,003 \\
2\end{array}$ & - & - & - & - & 0,131 & - \\
\hline & реднее: & 0,02 & $\begin{array}{c}0,15 \\
5 \\
\end{array}$ & & $\begin{array}{c}0,5 \\
3 \\
\end{array}$ & $\begin{array}{c}0,01 \\
3 \\
\end{array}$ & $\begin{array}{c}0,00 \\
7 \\
\end{array}$ & & $\begin{array}{c}0,10 \\
1\end{array}$ & $\begin{array}{c}0,0 \\
8\end{array}$ & $\begin{array}{c}0,00 \\
1 \\
\end{array}$ & 4,9 & $\begin{array}{c}0,014 \\
3 \\
\end{array}$ & 86 & $\begin{array}{c}0,01 \\
0 \\
\end{array}$ & $\begin{array}{c}0,002 \\
0\end{array}$ & & $\begin{array}{c}0,00 \\
8 \\
\end{array}$ & & & 0,069 & $\begin{array}{c}0,001 \\
4 \\
\end{array}$ \\
\hline \multicolumn{23}{|c|}{ VII груnna } \\
\hline 19 & 2018 & 0,01 & $\begin{array}{c}0,02 \\
7\end{array}$ & $\begin{array}{c}0,00 \\
3\end{array}$ & $\begin{array}{c}0,5 \\
0\end{array}$ & - & $\begin{array}{c}0,00 \\
5\end{array}$ & $\begin{array}{c}0,000 \\
1\end{array}$ & $\begin{array}{c}0,02 \\
0\end{array}$ & $\begin{array}{c}0,0 \\
2\end{array}$ & $\begin{array}{c}0,00 \\
5\end{array}$ & 7,2 & $\begin{array}{c}0,000 \\
7\end{array}$ & 7 & $\begin{array}{c}0,00 \\
7\end{array}$ & $\begin{array}{c}0,000 \\
9\end{array}$ & $\begin{array}{c}0,002 \\
0\end{array}$ & $\begin{array}{c}0,01 \\
2\end{array}$ & $\begin{array}{c}0,01 \\
9\end{array}$ & $\begin{array}{c}0,003 \\
4\end{array}$ & 0,027 & $\begin{array}{c}0,000 \\
5\end{array}$ \\
\hline 20 & 2018 & 0,01 & $\begin{array}{c}0,00 \\
8\end{array}$ & $\begin{array}{c}0,00 \\
3\end{array}$ & $\begin{array}{c}0,7 \\
0\end{array}$ & - & $\begin{array}{c}0,00 \\
1\end{array}$ & $\begin{array}{c}0,000 \\
4\end{array}$ & $\begin{array}{c}0,02 \\
0\end{array}$ & $\begin{array}{c}0,0 \\
3\end{array}$ & $\begin{array}{c}0,00 \\
6\end{array}$ & 6,0 & $\begin{array}{c}0,001 \\
8\end{array}$ & 14 & $\begin{array}{c}0,00 \\
6\end{array}$ & $\begin{array}{c}0,000 \\
7\end{array}$ & $\begin{array}{c}0,002 \\
5\end{array}$ & 0,011 & - & $\begin{array}{c}0,002 \\
8\end{array}$ & 0,069 & $\begin{array}{c}0,001 \\
4\end{array}$ \\
\hline 21 & 2018 & 0,01 & $\begin{array}{c}0,00 \\
7\end{array}$ & - & $\begin{array}{c}0,5 \\
0\end{array}$ & - & $\begin{array}{c}0,00 \\
3\end{array}$ & - & $\begin{array}{c}0,05 \\
0\end{array}$ & $\begin{array}{c}0,0 \\
3\end{array}$ & $\begin{array}{c}0,00 \\
2\end{array}$ & 6,8 & $\begin{array}{c}0,002 \\
8\end{array}$ & 13 & $\begin{array}{c}0,00 \\
4\end{array}$ & _. & $\begin{array}{c}0,000 \\
7\end{array}$ & $\begin{array}{c}0,00 \\
8\end{array}$ & - & $\begin{array}{c}0,001 \\
8\end{array}$ & 0,007 & - \\
\hline 22 & 2018 & 0,05 & $\begin{array}{c}0,03 \\
7 \\
\end{array}$ & $\begin{array}{c}0,00 \\
4\end{array}$ & $\begin{array}{c}0,6 \\
1 \\
\end{array}$ & $\begin{array}{c}0,00 \\
4\end{array}$ & $\begin{array}{c}0,00 \\
6\end{array}$ & - & $\begin{array}{c}0,03 \\
0 \\
\end{array}$ & $\begin{array}{c}0,0 \\
1 \\
\end{array}$ & $\begin{array}{c}0,01 \\
3\end{array}$ & 3,9 & $\begin{array}{c}0,003 \\
1\end{array}$ & 7 & $\begin{array}{c}0,01 \\
2\end{array}$ & $\begin{array}{c}0,003 \\
1\end{array}$ & $\begin{array}{c}0,001 \\
6\end{array}$ & $\begin{array}{c}0,04 \\
7 \\
\end{array}$ & - & $\begin{array}{c}0,000 \\
5\end{array}$ & 0,349 & $\begin{array}{c}0,000 \\
6\end{array}$ \\
\hline 23 & 2018 & 0,03 & $\begin{array}{c}0,02 \\
5\end{array}$ & $\begin{array}{c}0,00 \\
5\end{array}$ & $\begin{array}{c}0,5 \\
8\end{array}$ & $\begin{array}{c}0,00 \\
9\end{array}$ & $\begin{array}{c}0,01 \\
4\end{array}$ & & $\begin{array}{c}0,03 \\
9\end{array}$ & $\begin{array}{c}0,0 \\
1\end{array}$ & - & 10,6 & $\begin{array}{c}0,001 \\
6\end{array}$ & 21 & $\begin{array}{c}0,00 \\
5\end{array}$ & $\begin{array}{c}0,000 \\
4\end{array}$ & $\begin{array}{c}0,001 \\
2\end{array}$ & $\begin{array}{c}0,00 \\
2\end{array}$ & - & $\begin{array}{c}0,002 \\
7\end{array}$ & 0,410 & $\begin{array}{c}0,031 \\
0\end{array}$ \\
\hline 23 & 2019 & 0,00 & $\begin{array}{c}0,00 \\
6\end{array}$ & _ & $\begin{array}{c}0,0 \\
2\end{array}$ & - & - & - & - & $\begin{array}{c}0,2 \\
0\end{array}$ & - & 4,5 & - & 15 & - & - & - & - & $\begin{array}{c}0,01 \\
9\end{array}$ & $\begin{array}{c}0,001 \\
0\end{array}$ & 0,005 & - \\
\hline 24 & 2018 & 0,02 & $\begin{array}{c}0,00 \\
6\end{array}$ & $\begin{array}{c}0,00 \\
1\end{array}$ & $\begin{array}{c}0,3 \\
3\end{array}$ & $\begin{array}{c}0,00 \\
1\end{array}$ & $\begin{array}{c}0,00 \\
6\end{array}$ & - & $\begin{array}{c}0,03 \\
7\end{array}$ & $\begin{array}{c}0,0 \\
2\end{array}$ & $\begin{array}{c}0,02 \\
7\end{array}$ & 16,0 & $\begin{array}{c}0,001 \\
8\end{array}$ & 16 & $\begin{array}{c}0,00 \\
7\end{array}$ & $\begin{array}{c}0,002 \\
4\end{array}$ & _- & $\begin{array}{c}0,00 \\
4\end{array}$ & - & $\begin{array}{c}0,004 \\
1\end{array}$ & 0,127 & $\begin{array}{c}0,002 \\
1\end{array}$ \\
\hline 24 & 2019 & 0,01 & 0,011 & - & 0,0 & - & - & - & - & 0,2 & - & 11,8 & 0,002 & 19 & 0,00 & - & 0,001 & - & 0,04 & 0,000 & 0,003 & - \\
\hline
\end{tabular}




\begin{tabular}{|c|c|c|c|c|c|c|c|c|c|c|c|c|c|c|c|c|c|c|c|c|c|c|}
\hline & & & & & 3 & & & & & 0 & & & 4 & & 1 & & 5 & & 2 & 4 & & \\
\hline 25 & 2019 & 0,01 & $\begin{array}{c}0,00 \\
8\end{array}$ & - & $\begin{array}{c}0,0 \\
1\end{array}$ & $\begin{array}{c}0,00 \\
4\end{array}$ & $\begin{array}{c}0,00 \\
4\end{array}$ & - & $\begin{array}{c}0,00 \\
8\end{array}$ & $\begin{array}{c}0,2 \\
0\end{array}$ & - & 3,4 & - & 7 & $\begin{array}{c}0,00 \\
8\end{array}$ & - & $\begin{array}{c}0,003 \\
0\end{array}$ & - & $\begin{array}{c}0,02 \\
0\end{array}$ & $\begin{array}{c}0,000 \\
2\end{array}$ & 0,004 & - \\
\hline 25 & 2018 & 0,15 & $\begin{array}{c}0,05 \\
3 \\
\end{array}$ & - & $\begin{array}{c}0,6 \\
3\end{array}$ & $\begin{array}{c}0,05 \\
5\end{array}$ & $\begin{array}{c}0,03 \\
3\end{array}$ & $\begin{array}{c}0,001 \\
2\end{array}$ & $\begin{array}{c}0,02 \\
7\end{array}$ & $\begin{array}{c}0,0 \\
4\end{array}$ & $\begin{array}{c}0,00 \\
4 \\
\end{array}$ & 0,8 & $\begin{array}{c}0,016 \\
5\end{array}$ & 11 & $\begin{array}{c}0,04 \\
7 \\
\end{array}$ & $\begin{array}{c}0,001 \\
2\end{array}$ & $\begin{array}{c}0,002 \\
8\end{array}$ & $\begin{array}{c}0,00 \\
9\end{array}$ & - & 0,0011 & 0,306 & $\begin{array}{c}0,003 \\
2\end{array}$ \\
\hline \multicolumn{2}{|c|}{ Среднее: } & 0,03 & $\begin{array}{c}0,01 \\
9 \\
\end{array}$ & $\begin{array}{c}\mathbf{0 , 0 0} \\
3 \\
\end{array}$ & $\begin{array}{c}0,3 \\
9 \\
\end{array}$ & $\begin{array}{c}0,01 \\
5 \\
\end{array}$ & $\begin{array}{c}0,00 \\
9 \\
\end{array}$ & $\begin{array}{c}0,000 \\
6 \\
\end{array}$ & $\begin{array}{c}0,02 \\
9 \\
\end{array}$ & $\begin{array}{c}0,0 \\
8 \\
\end{array}$ & $\begin{array}{c}\mathbf{0 , 0 1} \\
0\end{array}$ & 7,1 & $\begin{array}{c}0,003 \\
8 \\
\end{array}$ & 13 & 0,011 & $\begin{array}{c}0,001 \\
5 \\
\end{array}$ & $\begin{array}{c}0,001 \\
9 \\
\end{array}$ & $\begin{array}{c}0,01 \\
3 \\
\end{array}$ & $\begin{array}{c}0,02 \\
5 \\
\end{array}$ & $\begin{array}{c}0,001 \\
8 \\
\end{array}$ & 0,131 & $\begin{array}{c}0,006 \\
5 \\
\end{array}$ \\
\hline \multicolumn{23}{|c|}{ VIII группа } \\
\hline 26 & 2019 & 0,04 & $\begin{array}{c}0,02 \\
0\end{array}$ & $\begin{array}{c}0,00 \\
1\end{array}$ & $\begin{array}{c}0,1 \\
0\end{array}$ & - & - & - & - & $\begin{array}{c}0,2 \\
8\end{array}$ & - & 41,3 & - & 13 & $\begin{array}{c}0,01 \\
2\end{array}$ & $\begin{array}{c}0,000 \\
6\end{array}$ & - & - & $\begin{array}{c}0,00 \\
9\end{array}$ & - & - & - \\
\hline 27 & 2019 & 0,01 & $\begin{array}{c}0,01 \\
6\end{array}$ & & $\begin{array}{c}0,0 \\
5\end{array}$ & - & - & - & $\begin{array}{c}0,00 \\
6\end{array}$ & $\begin{array}{c}0,2 \\
8\end{array}$ & - & 5,8 & - & 18 & $\begin{array}{c}0,00 \\
7\end{array}$ & & $\begin{array}{c}0,002 \\
3\end{array}$ & - & $\begin{array}{c}0,00 \\
8\end{array}$ & $\begin{array}{c}0,000 \\
2\end{array}$ & 0,007 & - \\
\hline 28 & 2019 & 0,01 & 0,011 & $\begin{array}{c}0,00 \\
3\end{array}$ & $\begin{array}{c}0,3 \\
0\end{array}$ & $\begin{array}{c}0,00 \\
1\end{array}$ & - & - & $\begin{array}{c}0,00 \\
4\end{array}$ & $\begin{array}{c}0,2 \\
2 \\
\end{array}$ & - & 17,4 & $\begin{array}{c}0,002 \\
0\end{array}$ & 62 & $\begin{array}{c}0,00 \\
7 \\
\end{array}$ & - & $\begin{array}{c}0,003 \\
8\end{array}$ & $\begin{array}{c}0,00 \\
9 \\
\end{array}$ & $\begin{array}{c}0,01 \\
9 \\
\end{array}$ & $\begin{array}{c}0,002 \\
4\end{array}$ & 0,021 & $\begin{array}{c}0,004 \\
0\end{array}$ \\
\hline 29 & 2018 & 0,02 & $\begin{array}{c}0,01 \\
6 \\
\end{array}$ & $\begin{array}{c}0,00 \\
2 \\
\end{array}$ & $\begin{array}{c}0,4 \\
6 \\
\end{array}$ & - & $\begin{array}{c}0,00 \\
2 \\
\end{array}$ & - & $\begin{array}{c}0,04 \\
5\end{array}$ & 0,11 & $\begin{array}{c}0,01 \\
5 \\
\end{array}$ & 9,7 & $\begin{array}{c}0,002 \\
8\end{array}$ & 17 & $\begin{array}{c}0,01 \\
0 \\
\end{array}$ & 0,0011 & $\begin{array}{c}0,002 \\
6\end{array}$ & $\begin{array}{c}0,01 \\
0 \\
\end{array}$ & $\begin{array}{c}0,02 \\
0 \\
\end{array}$ & $\begin{array}{c}0,009 \\
0\end{array}$ & 0,840 & $\begin{array}{c}0,001 \\
7\end{array}$ \\
\hline 29 & 2019 & 0,00 & $\begin{array}{c}0,00 \\
9\end{array}$ & - & $\begin{array}{c}0,0 \\
5\end{array}$ & - & - & - & $\begin{array}{c}0,00 \\
1\end{array}$ & $\begin{array}{c}0,1 \\
8\end{array}$ & - & 8,2 & - & 20 & - & - & - & - & - & - & - & - \\
\hline 30 & 2018 & 0,05 & $\begin{array}{c}0,00 \\
9\end{array}$ & - & $\begin{array}{c}0,6 \\
9\end{array}$ & $\begin{array}{c}0,00 \\
4\end{array}$ & $\begin{array}{c}0,00 \\
9\end{array}$ & - & $\begin{array}{c}0,12 \\
9\end{array}$ & $\begin{array}{c}0,0 \\
8\end{array}$ & - & 13,5 & - & 25 & $\begin{array}{c}0,01 \\
5\end{array}$ & - & - & - & - & $\begin{array}{c}0,003 \\
8\end{array}$ & 0,330 & 0,0011 \\
\hline 30 & 2019 & 0,00 & $\begin{array}{c}0,00 \\
8\end{array}$ & - & $\begin{array}{c}0,0 \\
4\end{array}$ & - & - & - & $\begin{array}{c}0,00 \\
3\end{array}$ & $\begin{array}{c}0,1 \\
8\end{array}$ & $\begin{array}{c}0,04 \\
5\end{array}$ & 8,4 & - & 20 & - & - & - & - & $\begin{array}{c}0,04 \\
0\end{array}$ & - & 0,003 & - \\
\hline \multicolumn{2}{|c|}{ Среднее: } & 0,02 & $\begin{array}{c}0,01 \\
3\end{array}$ & $\begin{array}{c}0,00 \\
2\end{array}$ & $\begin{array}{c}0,2 \\
4\end{array}$ & $\begin{array}{c}0,00 \\
3\end{array}$ & $\begin{array}{c}0,00 \\
6\end{array}$ & - & $\begin{array}{c}0,03 \\
1\end{array}$ & $\begin{array}{c}0,1 \\
9\end{array}$ & $\begin{array}{c}\mathbf{0 , 0 3} \\
0\end{array}$ & 14,9 & $\begin{array}{c}0,002 \\
4\end{array}$ & 25 & $\begin{array}{c}0,01 \\
0\end{array}$ & $\begin{array}{c}0,000 \\
8\end{array}$ & $\begin{array}{c}0,002 \\
9\end{array}$ & $\begin{array}{c}0,00 \\
9\end{array}$ & $\begin{array}{c}0,01 \\
9\end{array}$ & $\begin{array}{c}0,003 \\
8\end{array}$ & 0,240 & $\begin{array}{c}0,002 \\
3\end{array}$ \\
\hline & Фон: & 0,02 & $\begin{array}{c}0,02 \\
0\end{array}$ & $\begin{array}{c}0,00 \\
3\end{array}$ & $\begin{array}{c}0,4 \\
0\end{array}$ & $\begin{array}{c}0,00 \\
5\end{array}$ & $\begin{array}{c}0,00 \\
8\end{array}$ & 0,0 & $\begin{array}{c}0,02 \\
7\end{array}$ & $\begin{array}{c}0,1 \\
4\end{array}$ & $\begin{array}{c}0,01 \\
3\end{array}$ & 9,7 & $\begin{array}{c}0,002 \\
9\end{array}$ & 22 & $\begin{array}{c}0,01 \\
0\end{array}$ & $\begin{array}{c}0,001 \\
3\end{array}$ & $\begin{array}{c}0,001 \\
6\end{array}$ & $\begin{array}{c}0,00 \\
9\end{array}$ & $\begin{array}{c}0,02 \\
0\end{array}$ & $\begin{array}{c}0,002 \\
4\end{array}$ & 0,07 & $\begin{array}{c}0,002 \\
5\end{array}$ \\
\hline
\end{tabular}


Изотопный состав природных вод Байдарской долины

\begin{tabular}{|c|c|c|c|c|}
\hline № на рис. 1 & Год & $\delta^{13} \mathrm{C}_{\mathrm{VPDB}}$, \%о & $\delta \mathrm{D}_{\text {vsmow }}, \%$ & $\delta^{18} \mathrm{O}_{\text {vsmow }}, \%$ \\
\hline \multicolumn{5}{|c|}{ I групnа } \\
\hline 1 & 2018 & $-10,0$ & $-40,0$ & $-5,6$ \\
\hline 1 & 2019 & $-11,6$ & $-39,6$ & $-5,3$ \\
\hline 2 & 2018 & $-12,8$ & $-59,0$ & $-8,9$ \\
\hline 2 & 2019 & $-12,4$ & $-57,6$ & $-8,7$ \\
\hline 3 & 2018 & $-15,0$ & $-58,0$ & $-8,6$ \\
\hline 3 & 2019 & $-13,4$ & $-54,5$ & $-8,9$ \\
\hline 4 & 2018 & $-10,7$ & $-61,0$ & $-9,3$ \\
\hline 4 & 2019 & $-11,0$ & $-59,1$ & $-9,0$ \\
\hline 5 & $2018^{*}$ & $-13,0$ & $-55,0$ & $-8,8$ \\
\hline \multicolumn{2}{|c|}{ Среднее значение: } & $-12,2$ & $-53,8$ & $-8,1$ \\
\hline \multicolumn{5}{|c|}{ II груnna } \\
\hline 6 & 2018 & $-13,0$ & $-49,0$ & $-7,1$ \\
\hline 6 & 2019 & $-13,3$ & $-51,5$ & $-7,5$ \\
\hline 7 & 2018 & $-12,5$ & $-55,0$ & $-8,4$ \\
\hline 7 & 2019 & $-12,1$ & $-60,0$ & $-8,6$ \\
\hline \multicolumn{2}{|c|}{ Среднее значение: } & $-12,7$ & $-53,9$ & $-7,9$ \\
\hline \multicolumn{5}{|c|}{ III грynna } \\
\hline 8 & 2018 & $-13,6$ & $-58,6$ & $-8,8$ \\
\hline 8 & 2019 & $-14,2$ & $-52,0$ & $-8,9$ \\
\hline 9 & $2018^{*}$ & $-12,9$ & $-59,0$ & $-9,1$ \\
\hline 10 & 2019 & $-12,2$ & $-58,2$ & $-8,7$ \\
\hline \multicolumn{2}{|c|}{ Среднее значение: } & $-13,2$ & $-57,0$ & $-8,9$ \\
\hline \multicolumn{5}{|c|}{ IV группа } \\
\hline 11 & 2018* & $-12,3$ & $-54,0$ & $-7,9$ \\
\hline 12 & 2019 & $-12,4$ & $-52,0$ & $-8,0$ \\
\hline 13 & 2019 & $-11,5$ & $-52,0$ & $-1,1$ \\
\hline 14 & $2018 *$ & $-12,8$ & $-53,0$ & $-8,2$ \\
\hline \multicolumn{2}{|c|}{ Среднее значение: } & $-12,3$ & $-52,8$ & $-6,3$ \\
\hline \multicolumn{5}{|c|}{ V группа } \\
\hline 15 & 2018* & $-15,5$ & $-51,0$ & $-7,9$ \\
\hline 16 & 2018* & $-6,9$ & $-51,0$ & $-8,3$ \\
\hline \multicolumn{2}{|c|}{ Среднее значение: } & $-12,3$ & $-52,8$ & $-6,3$ \\
\hline \multicolumn{5}{|c|}{ VI групnа } \\
\hline 17 & 2018 & $-14,2$ & $-59,0$ & $-9,1$ \\
\hline 17 & 2019 & $-14,8$ & $-59,3$ & $-8,8$ \\
\hline 18 & $2018^{*}$ & $-13,6$ & $-56,0$ & $-8,5$ \\
\hline \multicolumn{2}{|c|}{ Среднее значение: } & $-14,2$ & $-58,1$ & $-8,8$ \\
\hline \multicolumn{5}{|c|}{ VII грynna } \\
\hline 19 & 2018 & $-12,3$ & $-56,0$ & $-8,9$ \\
\hline 20 & 2018 & $-11,1$ & $-64,0$ & $-9,5$ \\
\hline 21 & 2018 & $-11,0$ & $-59,0$ & $-9,1$ \\
\hline 22 & 2018 & $-12,6$ & $-54,0$ & $-9,7$ \\
\hline 23 & 2018 & $-11,2$ & $-60,0$ & $-9,5$ \\
\hline 23 & 2019 & $-12,0$ & $-64,2$ & $-9,8$ \\
\hline 24 & 2018 & $-11,4$ & $-60,0$ & $-9,3$ \\
\hline 24 & 2019 & $-11,8$ & $-63,9$ & $-9,6$ \\
\hline 25 & 2019 & $-12,3$ & $-61,9$ & $-9,9$ \\
\hline 25 & 2018 & $-12,8$ & $-64,0$ & $-9,3$ \\
\hline \multicolumn{2}{|c|}{ Среднее значение: } & $-14,2$ & $-58,1$ & $-8,8$ \\
\hline \multicolumn{5}{|c|}{$\begin{array}{ll}\text { VIII групnа } \\
\end{array}$} \\
\hline 26 & 2019 & $-6,2$ & $-33,3$ & $-3,4$ \\
\hline 27 & 2019 & $-7,8$ & $-32,5$ & $-3,0$ \\
\hline 28 & 2019 & $-6,8$ & $-44,1$ & $-5,2$ \\
\hline 29 & 2018 & $-7,0$ & $-46,0$ & $-6,8$ \\
\hline 29 & 2019 & $-7,2$ & $-47,7$ & $-6,7$ \\
\hline 30 & 2018 & $-9,2$ & $-52,0$ & $-7,5$ \\
\hline \multirow{2}{*}{\multicolumn{2}{|c|}{$\frac{2019}{\text { Среднее значение: }}$}} & $-8,9$ & $-50,3$ & $-7,2$ \\
\hline & & $-7,6$ & $-45,6$ & $-6,4$ \\
\hline
\end{tabular}

Примечание: название геохимической группы природных вод приведено в таблице 1. 


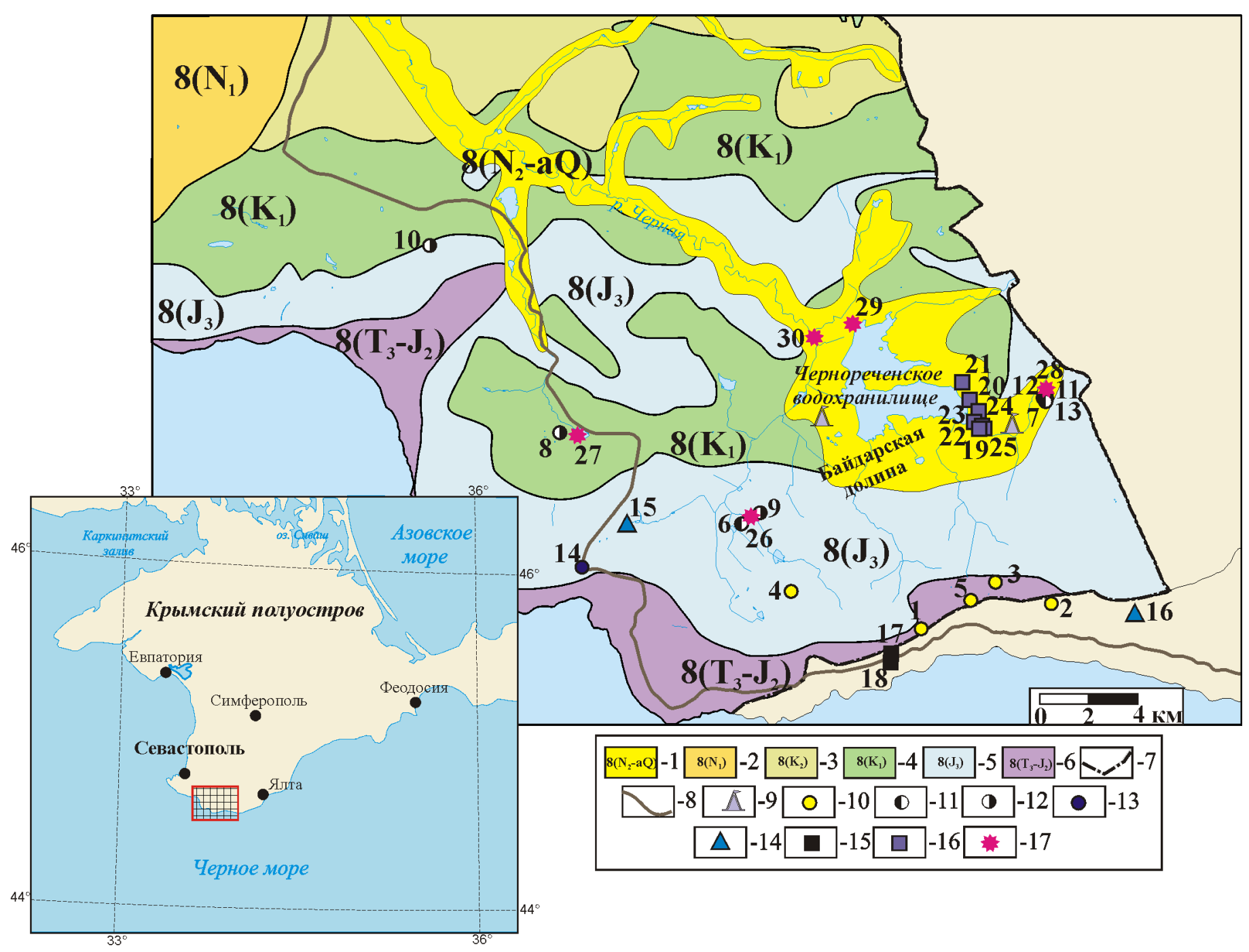




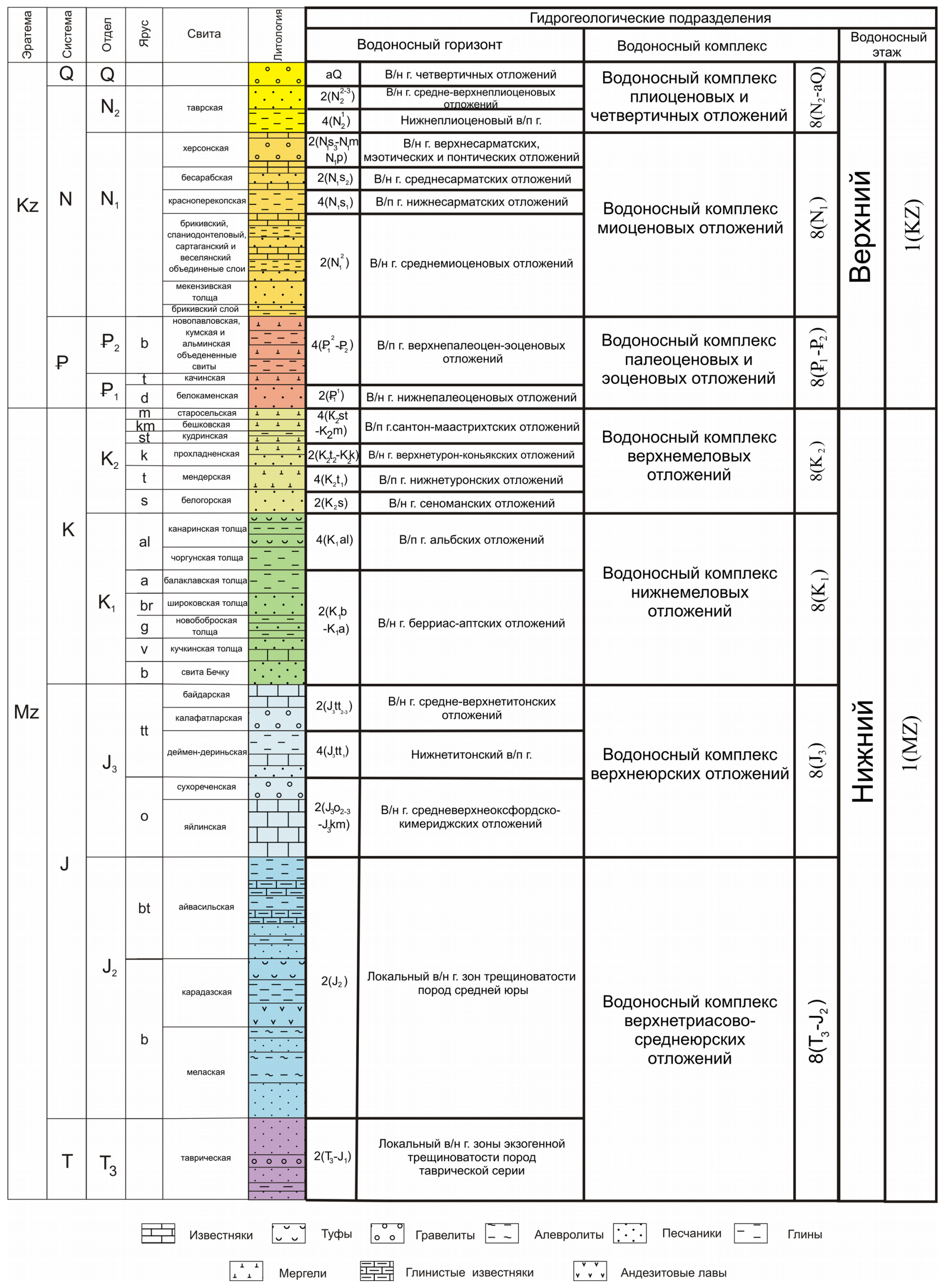



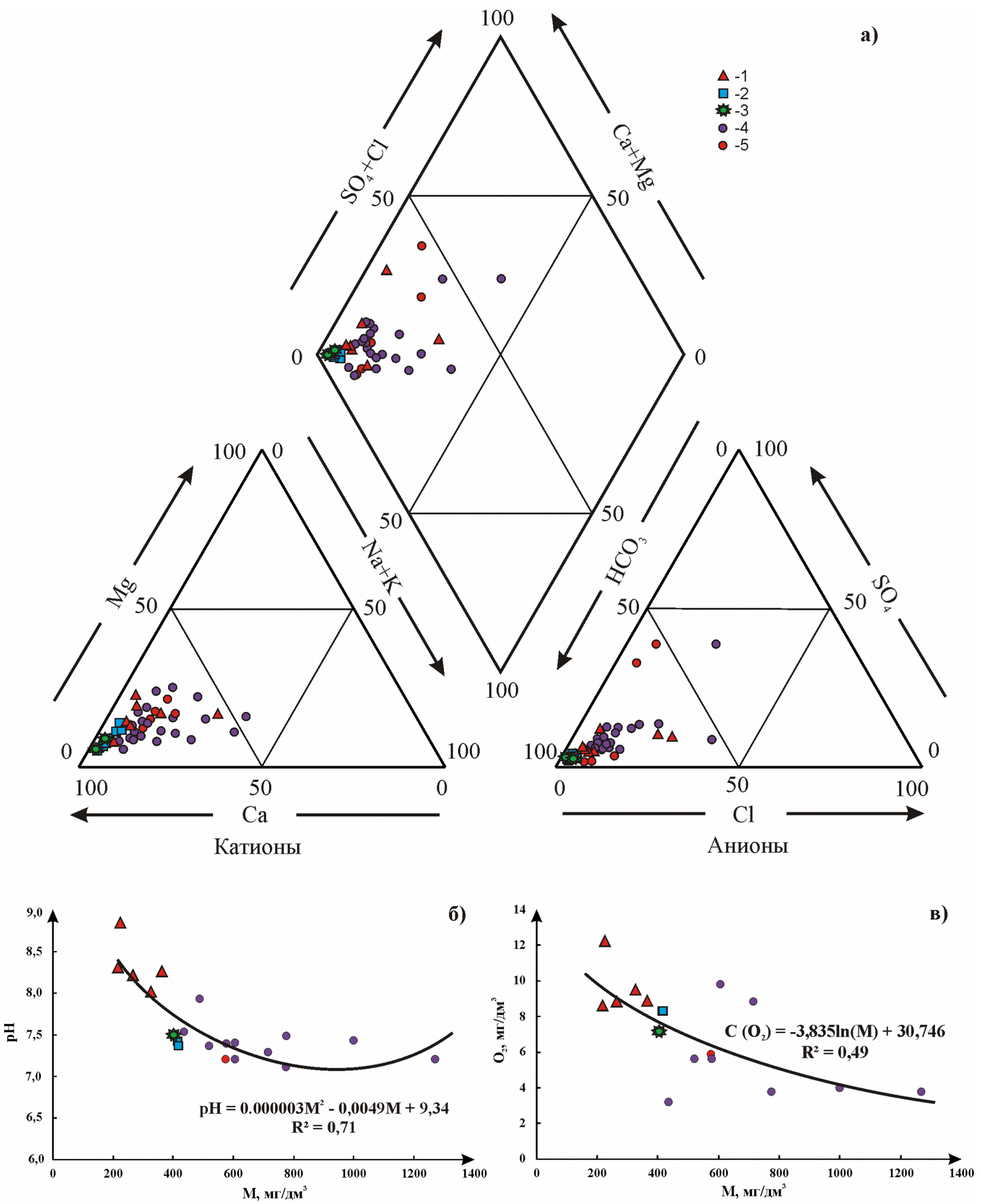

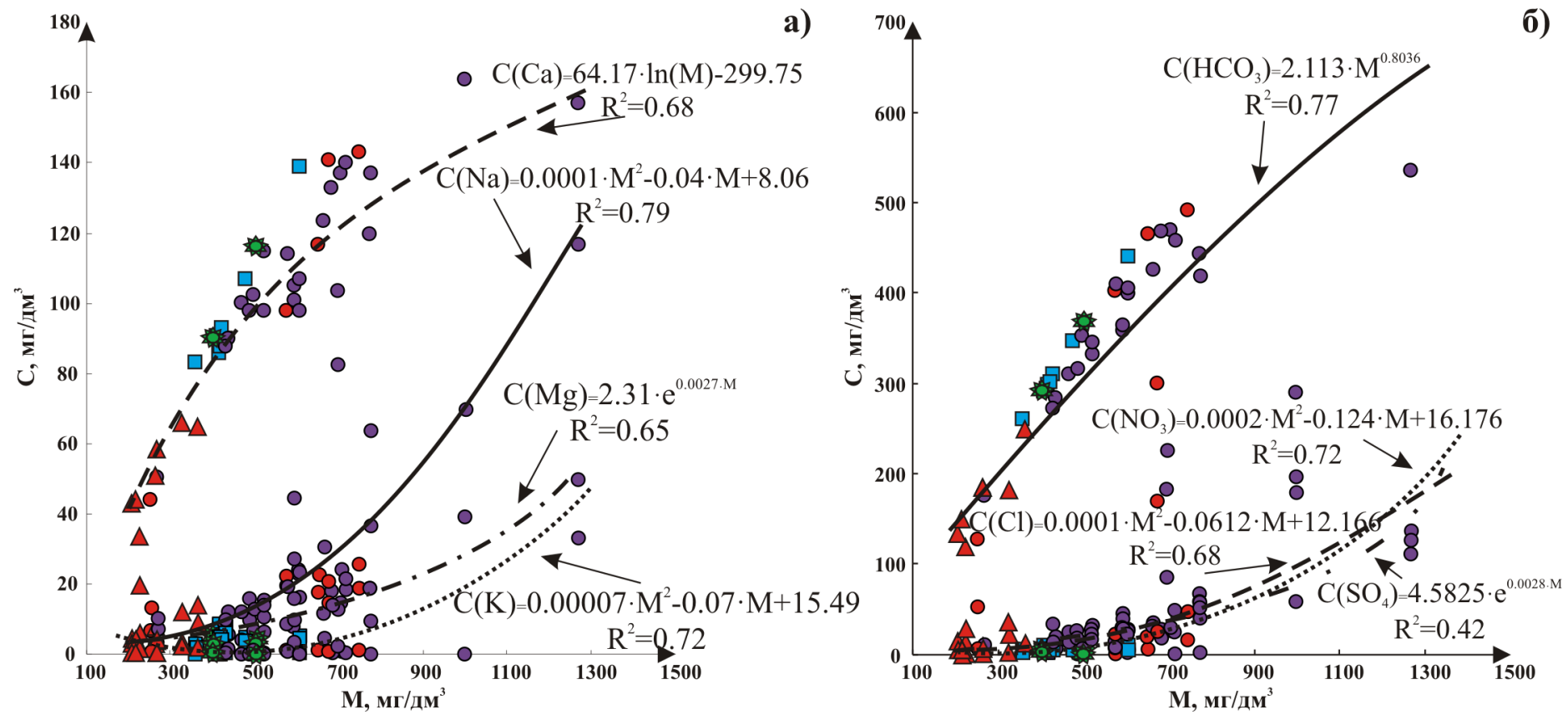

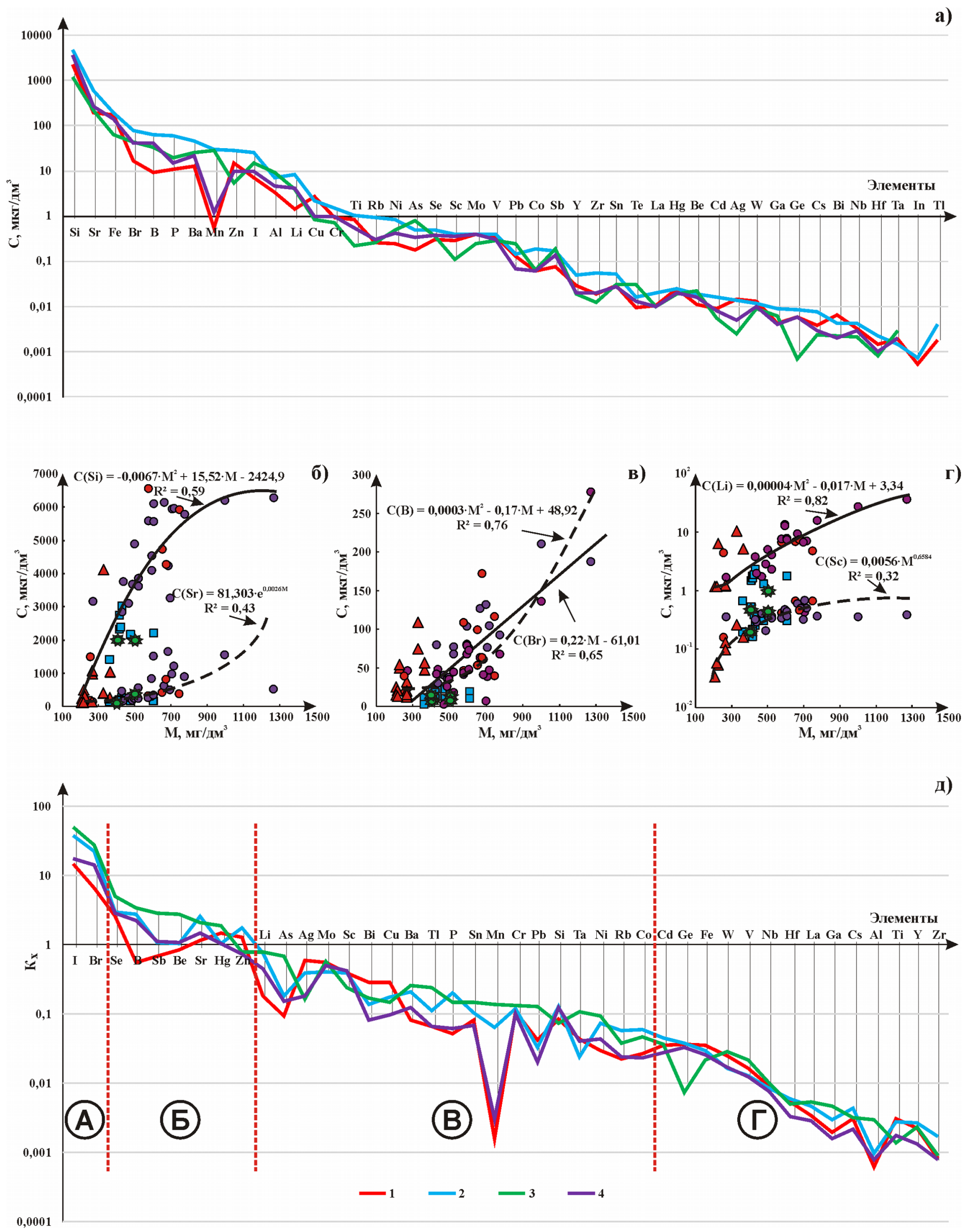
a)

б)
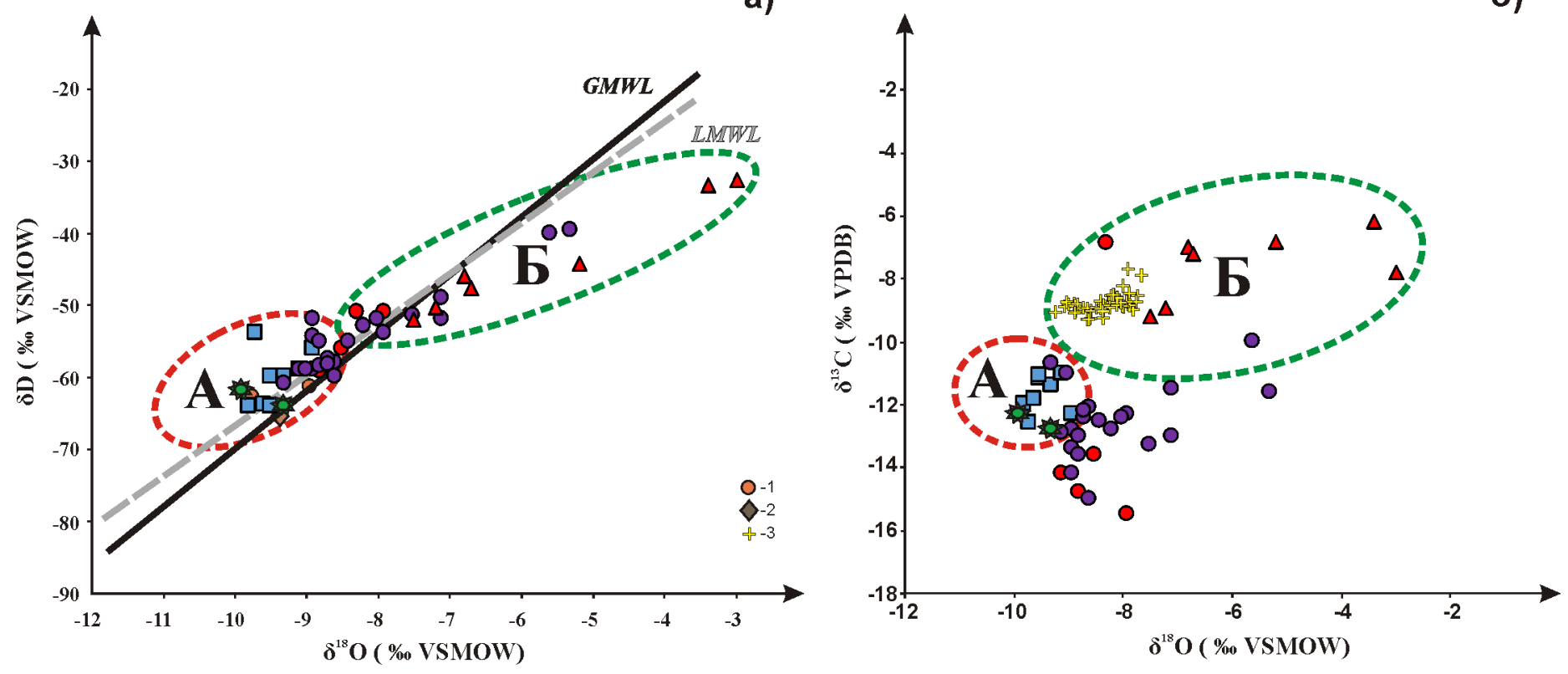